\section{ESRI}

RESEARCH

SERIES

NUMBER 96

January 2020

\section{NATIONAL STATUSES GRANTED FOR PROTECTION REASONS \\ IN IRELAND}

SARAH GROARKE AND PATRICIA BRAZIL

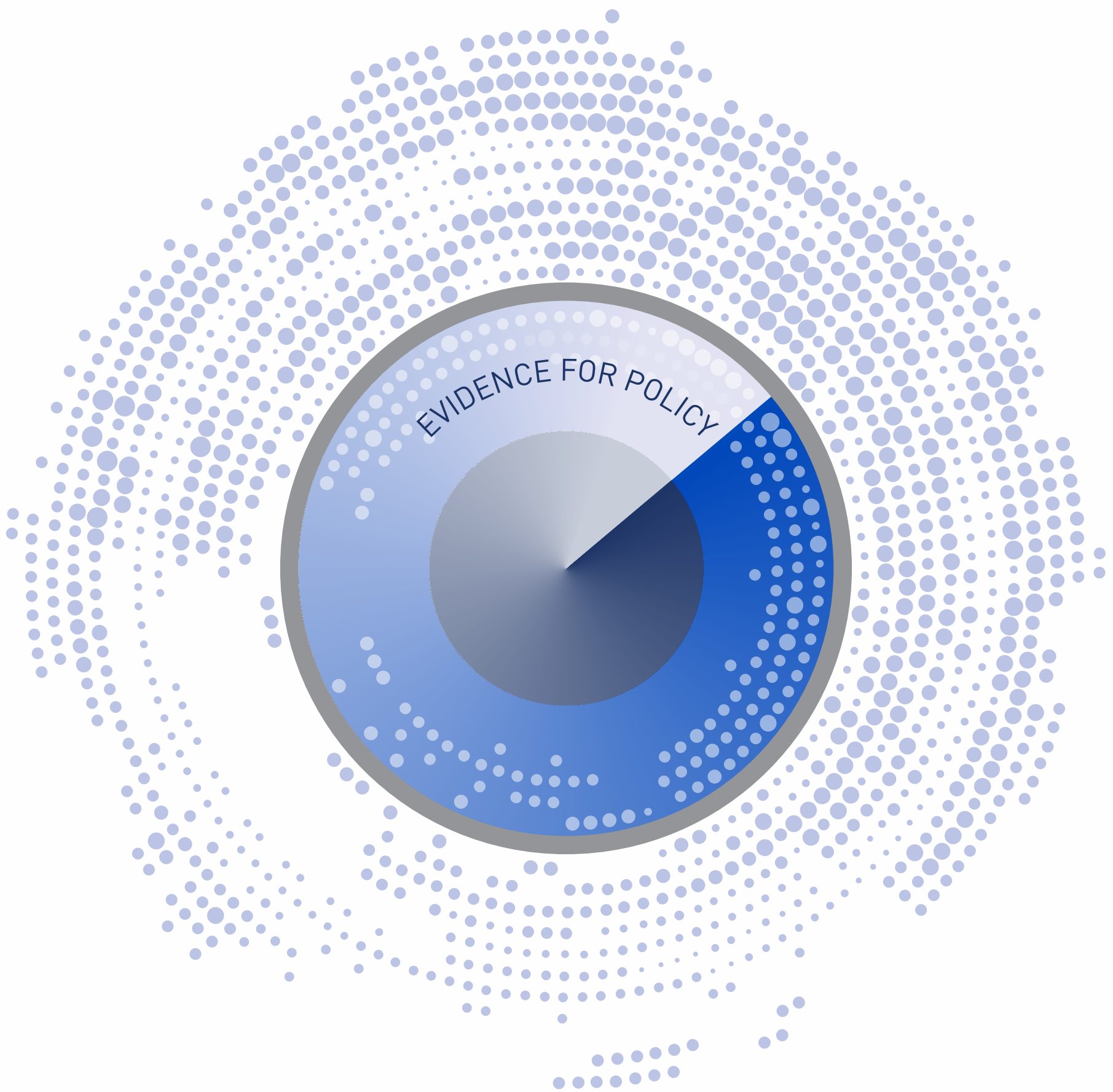





\title{
NATIONAL STATUSES GRANTED FOR PROTECTION REASONS IN IRELAND
}

\author{
Sarah Groarke
}

Patricia Brazil

January 2020

\section{RESEARCH SERIES}

\section{NUMBER 96}

Study completed by the Irish National Contact Point of the European Migration Network (EMN), which is financially supported by the European Union and the Irish Department of Justice and Equality. The EMN was established via Council Decision 2008/381/EC.

Available to download from www.emn.ie.

(C) The Economic and Social Research Institute

Whitaker Square, Sir John Rogerson's Quay, Dublin 2

ISBN: 978-0-7070-0507-2

DOI: https://doi.org/10.26504/rs96

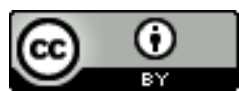

This Open Access work is licensed under a Creative Commons Attribution 4.0 International License, which permits unrestricted use, distribution, and reproduction in any medium, provided the original work is properly credited. 



\section{THE EUROPEAN MIGRATION NETWORK}

The aim of the European Migration Network (EMN) is to provide up-to-date, objective, reliable and comparable information on migration and asylum at Member State and EU levels with a view to supporting policymaking and informing the general public.

The Irish National Contact Point of the European Migration Network, EMN Ireland, sits within the Economic and Social Research Institute (ESRI).

\section{ABOUT THE ESRI}

The mission of the Economic and Social Research Institute is to advance evidencebased policymaking that supports economic sustainability and social progress in Ireland. ESRI researchers apply the highest standards of academic excellence to challenges facing policymakers, focusing on 12 areas of critical importance to 21st Century Ireland.

The Institute was founded in 1960 by a group of senior civil servants led by Dr T.K. Whitaker, who identified the need for independent and in-depth research analysis to provide a robust evidence base for policymaking in Ireland.

Since then, the Institute has remained committed to independent research and its work is free of any expressed ideology or political position. The Institute publishes all research reaching the appropriate academic standard, irrespective of its findings or who funds the research.

The quality of its research output is guaranteed by a rigorous peer review process. ESRI researchers are experts in their fields and are committed to producing work that meets the highest academic standards and practices.

The work of the Institute is disseminated widely in books, journal articles and reports. ESRI publications are available to download, free of charge, from its website. Additionally, ESRI staff communicate research findings at regular conferences and seminars.

The ESRI is a company limited by guarantee, answerable to its members and governed by a Council, comprising 14 members who represent a cross-section of ESRI members from academia, civil services, state agencies, businesses and civil society. The Institute receives an annual grant-in-aid from the Department of Public Expenditure and Reform to support the scientific and public interest elements of the Institute's activities; the grant accounted for an average of 30 per cent of the Institute's income over the lifetime of the last Research Strategy. The remaining funding comes from research programmes supported by government departments and agencies, public bodies and competitive research programmes.

Further information is available at www.esri.ie. 


\section{THE AUTHORS}

Sarah Groarke is Policy Officer at the Irish National Contact Point of the European Migration Network (EMN Ireland). Patricia Brazil LLB, MLitt, PhD, Barrister-at-Law, is Averil Deverell Assistant Professor in Law at Trinity College Dublin and legal consultant for EMN Ireland.

\section{ACKNOWLEDGEMENTS}

In compiling this study, valuable assistance was received from representatives of the Department of Justice and Equality and the Irish Refugee Council. Thanks are also due to representatives of UNHCR Ireland for their input on an early draft of the EMN study template. We also acknowledge the useful comments and suggestions received from the referees. Finally, thanks are due to our colleagues Sarah Burns, Elaine Byrne, Emma Quinn and Anne Sheridan at the ESRI. We are grateful to everyone who shared their expertise with us for the purpose of writing this study.

\section{ABOUT THIS REPORT}

This European Migration Network study provides an overview of the national statuses that may be granted to persons for protection reasons in Ireland. The report focuses on national statuses with a basis in Irish domestic law and policy. It consists of information gathered by way of a common template, primarily for a forthcoming EU-level synthesis report: Comparative overview of national protection statuses, which will be published at: www.emn.ie and www.ec.europa.eu/emn.

This report has been accepted for publication by the Institute, which does not itself take institutional policy positions. All ESRI Research Series reports are peer reviewed prior to publication. The authors are solely responsible for the content and the views expressed do not represent the position of the Economic and Social Research Institute, the Department of Justice and Equality, or the European Commission, Directorate-General Migration and Home Affairs. 


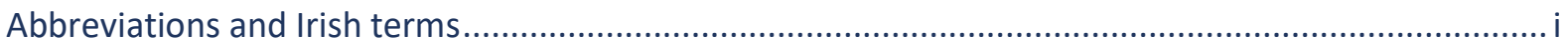

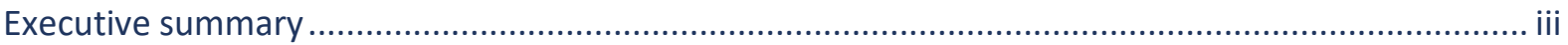

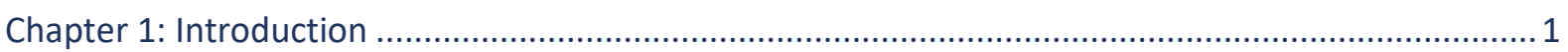

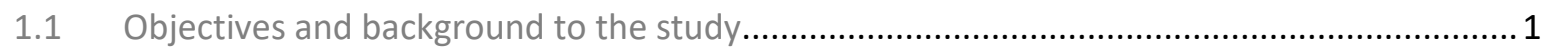

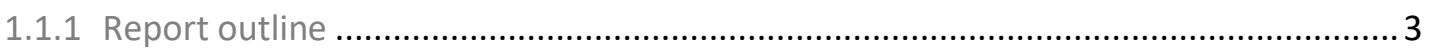

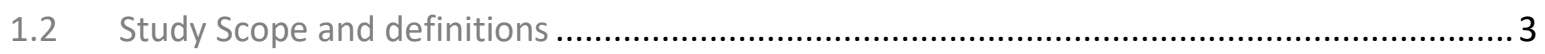

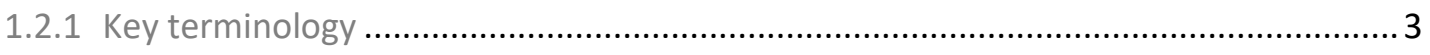

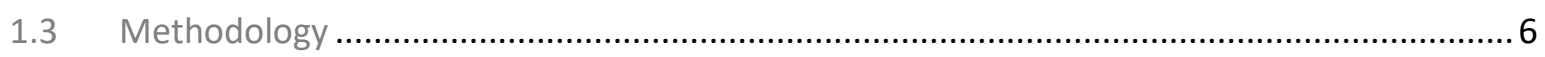

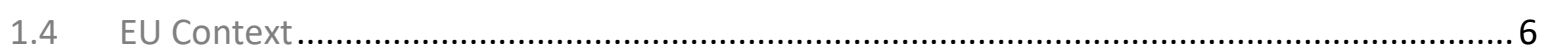

1.4.1 Overview of trends regarding protection-related statuses in the EU.....................10

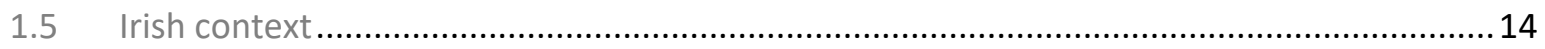

1.5.1 Non-EU harmonised national statuses that may be granted for protection reasons. 15

1.5.2 Overview of trends regarding protection-related statuses in Ireland ......................17

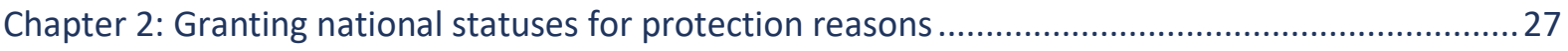

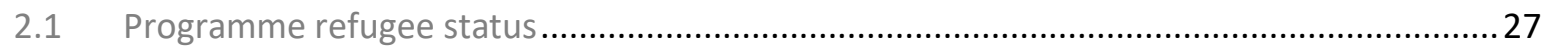

2.1.1 Irish Refugee Resettlement Programme (IRRP) ............................................. 28

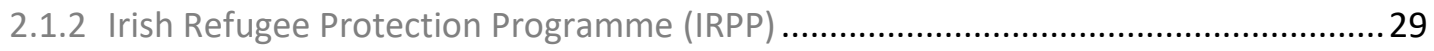

2.1.3 Irish Refugee Protection Programme Humanitarian Admission Programme (IHAP).. 31

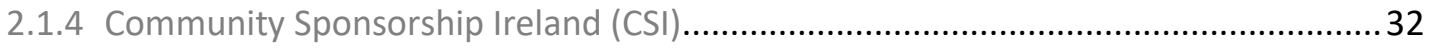

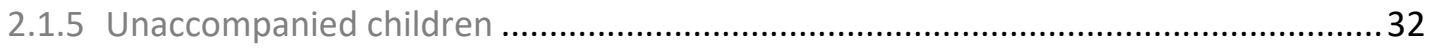

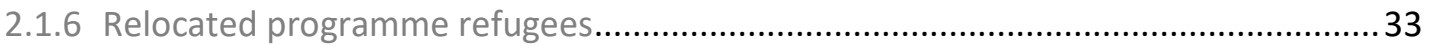

2.1.7 Profile of persons granted programme refugee status.......................................33

2.2 Permission to remain under section 49 of the International Protection Act 2015 ..............36

2.2.1 Persons that may be granted permission to remain under section 49 of the 2015 Act.

2.2.2 Determination procedure ..................................................................... 38

2.2.3 Profile of persons granted permission to remain under section 49 of the 2015 Act .40

2.3 Permission to remain under section 50 of the 2015 Act as an unsuccessful applicant for international protection who cannot be refouled

2.4 Leave to remain following a decision not to make a deportation order under section 3 of the Immigration Act 1999.

2.4.1 Unsuccessful international protection applicants....

2.4.2 Profile of persons who submitted an international protection application and were granted leave to remain following a decision not to make a deportation order under section 3 of the 1999 Act 
2.5 Permission to remain under section 4 of the Immigration Act 2004 ...................................52

2.6 Syrian Humanitarian Admission Programme (SHAP) .........................................................53

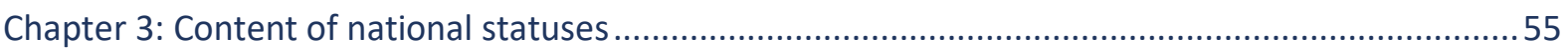

3.1 International protection and temporary protection status .................................................5

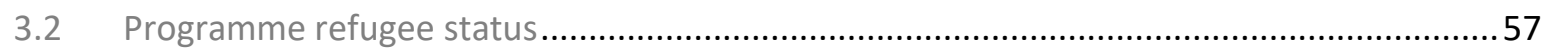

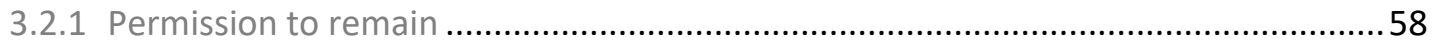

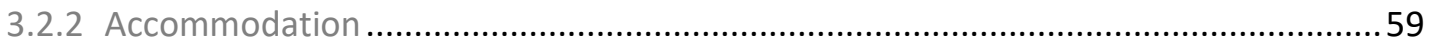

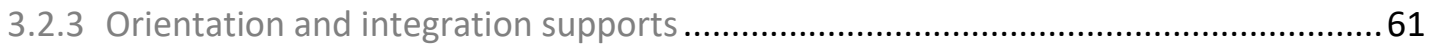

3.2.4 Employment, education, medical care and social welfare .......................................63

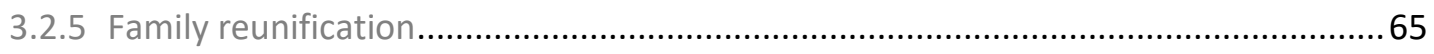

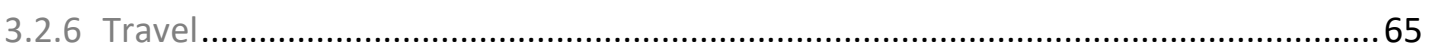

3.3 Permission to remain under section 49 of the International Protection Act 2015 ...............66

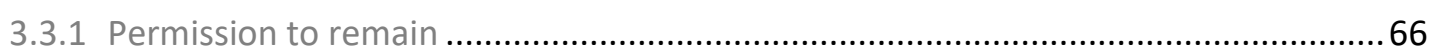

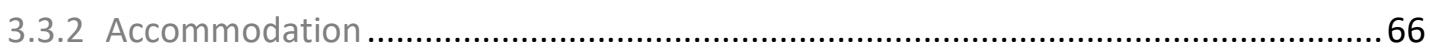

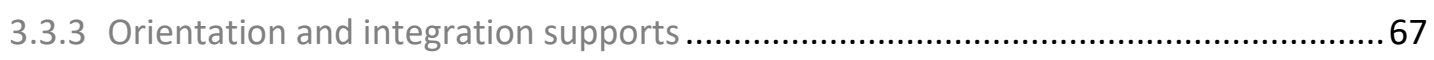

3.3.4 Employment, education, medical care and social welfare .......................................67

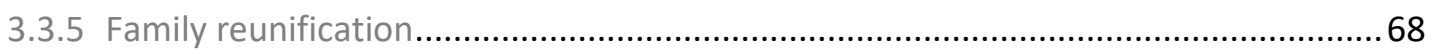

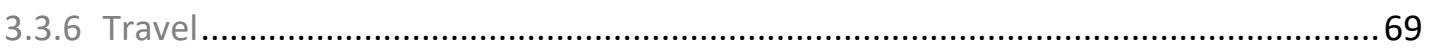

3.4 Leave to remain following a decision not to make a deportation order under section 3 of

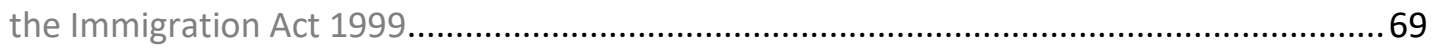

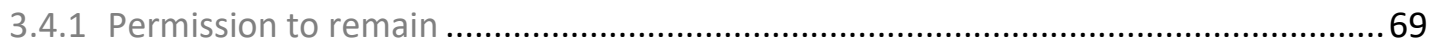

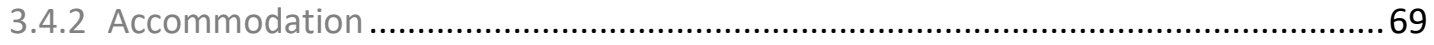

3.4.3 Orientation and integration supports ..................................................................... 70

3.4.4 Employment, education, medical care and social welfare ........................................ 70

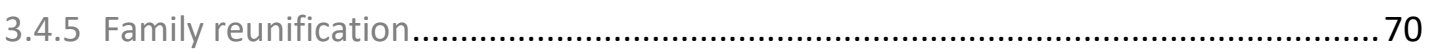

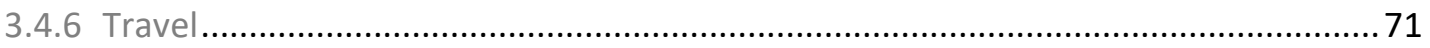

3.5 Permission to remain under section 4 of the Immigration Act 2004 ..................................... 71

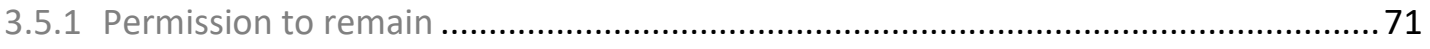

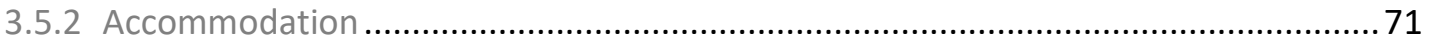

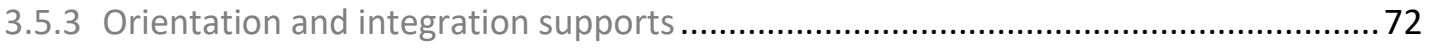

3.5.4 Employment, education, medical care and social welfare ......................................... 72

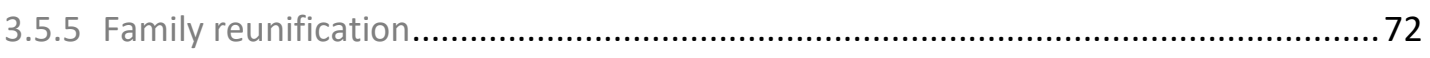

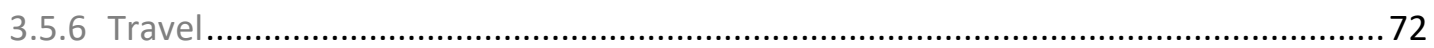

3.6 Syrian Humanitarian Admission Programme (SHAP) ........................................................ 73

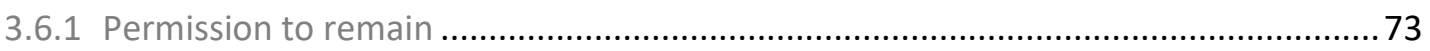




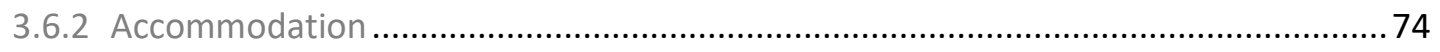

3.6.3 Orientation and integration supports .................................................................... 74

3.6.4 Employment, education, medical care and social welfare ........................................ 74

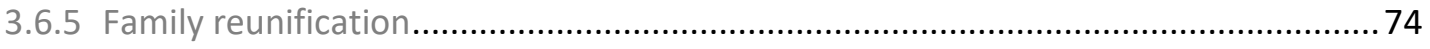

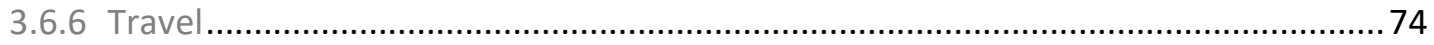

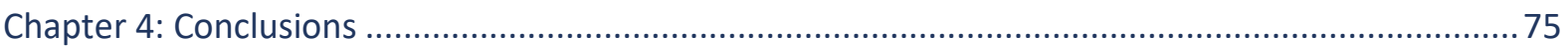

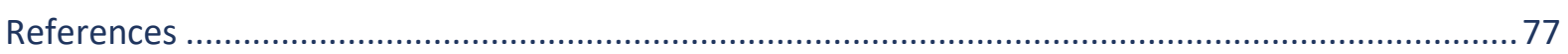




\section{LIST OF TABLES}

Table 1.1 Top five countries of origin of persons granted authorisations to stay for humanitarian reasons at first instance, 2010-2018

Table 1.2 Persons granted programme refugee status, Convention refugee status, subsidiary protection, permission to remain under section 49 of the 2015 Act and persons who previously submitted an internatonal protection application granted leave to remain following a decision not to deport under the 1999 Act, 2010-2018.

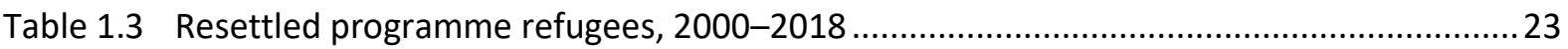

Table 2.1 Country of origin of persons granted programme refugee status, 2010-2018 ................34

Table 2.2 Country of origin of 141 beneficiaries approved under IHAP...... 36

Table 2.3 Country of origin of persons granted permission to remain under section 49 of the 2015 Act, 2017-2018

Table 2.4 Total grants of leave to remain following a decision not to make a deportation order under section 3 of the Immigration Act 1999 to persons who had made an international

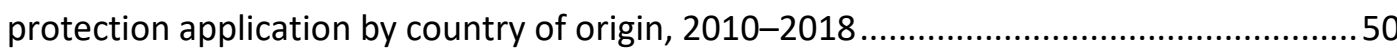

Table 3.1 Summary of content of protection granted to status holders 56

\section{LIST OF FIGURES}

Figure 1.1 Total first-instance positive decisions in EU Member States, including refugee status, subsidiary protection and authorisations to stay for humanitarian reasons, 2010-2018.11

Figure 1.2 Total final positive decisions in EU Member States, including refugee status, subsidiary protection and authorisations to stay for humanitarian reasons, 2010-2018

Figure 1.3 Persons granted leave to remain following a decision not to make a deportation order under section 3 of the Immigration Act 1999, 2010-2018 .............................................25

Figure 2.1 Persons granted programme refugee status by age, 2010-2018 …................................ 35

Figure 2.2 Persons granted programme refugee status by gender, 2010-2018 ............................... 35

Figure 2.3 Persons granted permission to remain under section 49 of the 2015 Act by age, 20172018

Figure 2.4 Persons granted permission to remain under section 49 of the 2015 Act by gender, 20172018

Figure 2.5 Persons granted leave to remain following a decision not to make a deportation order under section 3 of the Immigration Act 1999 having previously submitted an international protection, by age, 2010-2018.

Figure 2.6 Persons granted leave to remain following a decision not to make a deportation order under section 3 of the Immigration Act 1999 having previously submitted an international protection, by gender, $2010-2018$ 


\section{ABBREVIATIONS AND IRISH TERMS}

CEAS

CSI

Dáil

DRC

EMN

ESRI

EROC

ETB

EU

GNIB

GP

IHAP

INIS

IPAT

IPO

IRPP

IRRP

MAP

NGO

ORAC

PPS

RAU

SHAP

SUSI

Tánaiste

TD

TFEU

UN

UNHCR

YES
Common European Asylum System

Community Sponsorship Ireland

Parliament, lower house

Democratic Republic of the Congo

European Migration Network

Economic and Social Research Institute

Emergency Reception and Orientation Centre

Education and Training Board

European Union

Garda National Immigration Bureau

General practitioner

Irish Refugee Protection Programme Humanitarian Admission

Programme

Irish Naturalisation and Immigration Service

International Protection Appeals Tribunal

International Protection Office

Irish Refugee Protection Programme

Irish Refugee Resettlement Programme

Migrant Access Programme

Non-governmental organisation

Office of the Refugee Applications Commissioner

Personal public service number

Reporting and Analysis Unit (of the Department of Justice and Equality)

Syrian Humanitarian Admission Programme

Student Universal Support Ireland

Irish deputy prime minister

Teachta Dála - Member of Parliament

Treaty on the Functioning of the European Union

United Nations

United Nations High Commissioner for Refugees

Youth and Education Service for Refugees and Migrants 



\section{EXECUTIVE SUMMARY}

This study examines the national statuses that may be granted for protection reasons in Ireland. The report focuses on national statuses with a sole basis in Irish domestic law and policy and does not examine in detail EU-harmonised statuses. The national statuses discussed in this report are diverse in terms of their policy objectives, legal basis, procedure and content. However, it provides an overview of the potential means of regularising the status of those with a protection need that is not EU-harmonised. The study covers statuses that were granted in Ireland between 2010 and 2018 and includes any statuses that were introduced and subsequently ceased during the study period.

The 1951 Convention relating to the Status of Refugees (1951 Refugee Convention) and the 1967 Protocol relating to the Status of Refugees together form the cornerstone of international protection for persons who have been forced to flee their country due to persecution. The 1951 Refugee Convention sets out the definition of a refugee and the standards of protection to which persons recognised as a refugee are entitled.

In the EU context, the EU Qualification Directive seeks to harmonise the status granted to persons seeking protection across the EU and ensure a minimum level of rights afforded to persons recognised as refugees or subsidiary protection beneficiaries. Nevertheless, a wide variety of non-harmonised statuses or national statuses granted to non-EU nationals for protection reasons are in place at national level across EU Member States (EMN, 2010).

In Ireland, the International Protection Act 2015 (the 2015 Act) gives effect to Ireland's obligations under the 1951 Refugee Convention and incorporates EUharmonised provisions governing international protection contained in the 2004 Qualification Directive. The 2015 Act provides that a successful international protection applicant may be granted refugee status or subsidiary protection. In addition to the two core international protection statuses, Irish law sets out a number of national statuses for persons with a protection need.

\section{PROGRAMME REFUGEE STATUS}

Section 59 of the International Protection Act 2015 (the 2015 Act) provides for the granting of programme refugee status to a person to whom permission to enter and remain in the State for resettlement or temporary protection has been granted by the Government or Minister for Justice and Equality (the Minister). The status was first introduced in the 1996 Act to provide clarity on the legal status granted 
to people resettled to Ireland since the $1950 \mathrm{~s} .{ }^{1}$ The majority of persons granted programme refugee status each year are refugees resettled to Ireland under the Irish Refugee Resettlement Programme (IRRP), which since 2015 has taken place under the Irish Refugee Protection Programme (IRPP). Persons who arrive in Ireland through the IRPP Humanitarian Admission Programme (IHAP) and the Community Sponsorship Ireland (CSI) initiative, as well as most unaccompanied children who arrived under the Calais Special Project, are also granted programme refugee status.

The period between 2010 and 2018 saw a gradual increase in the number of persons granted programme refugee status annually, in large part as a result of Ireland's increased resettlement commitments under the IRPP and ad hoc schemes established in recent years to admit persons to Ireland for protection. A total of 1,480 persons were granted programme refugee status between 2010 and $2018 .^{2}$

Programme refugees, like international protection beneficiaries, or 'Convention refugees', are generally provided with rights and privileges similar to those enjoyed by Irish citizens. Programme refugees resettled under the IRRP and IRPP, as well as the CSI initiative, are the only groups to have access to targeted integration supports (Gusciute et al., 2016; Arnold et al., 2019).

\section{PERMISSION TO REMAIN PURSUANT TO SECTION 49 OF THE INTERNATIONAL PROTECTION ACT 2015}

Section 49 of the 2015 Act states that, where an applicant receives a negative decision on an international protection application, the Minister must consider whether to give the applicant permission to remain in the State. In addition to spontaneous applicants for international protection, persons arriving through the relocation strand of the IRPP and through search and rescue missions may be granted permission to remain under section 49 of the 2015 Act, following submission of an application for international protection. In 2017, 72 people were granted permission to remain under section 49 of the 2015 Act, while 238 people were granted this status in $2018 .^{3}$

The rights enjoyed by persons granted permission to remain under section 49 of the 2015 Act are not provided for in legislation. Due to the highly discretionary nature of this status, there is less clarity regarding the rights and entitlements of holders of permission to remain. Some persons granted permission to remain under section 49 of the 2015 Act may have less favourable conditions compared to 
international protection beneficiaries granted refugee status or subsidiary protection or programme refugees.

As is the case for beneficiaries of international protection and programme refugees, persons granted permission to remain under section 49 of the 2015 Act are in practice issued with a Stamp 4 residence permission, which entitles the holder to seek and enter employment and access social welfare, provided that all qualifying conditions are satisfied. ${ }^{4}$ However, unlike the beneficiaries of international protection granted refugee status or subsidiary protection and those granted leave to remain following a decision not to make a deportation order under section 3 of the Immigration Act 1999, persons granted permission to remain under section 49 of the 2015 Act are currently not eligible for financial support to access third-level education under the Free Fees Initiative (O'Kelly, 2019). ${ }^{5}$ In addition, in contrast with beneficiaries of international protection, persons granted permission to remain under section 49 of the 2015 Act are required to obtain their own national passport to travel and are not entitled to a travel document, unless they can demonstrate they cannot obtain a national passport (INIS, 2017b).

\section{LEAVE TO REMAIN FOLLOWING A DECISION NOT TO MAKE A DEPORTATION ORDER PURSUANT TO SECTION 3 OF THE IMMIGRATION ACT 1999}

The Immigration Act 1999 (as amended) (the 1999 Act) governs the legal procedures for deportation from the State. Section 3 of the 1999 Act sets out the Minister's power to make a deportation order against a non-national; it requires the person in question to leave the State and to remain outside of the State. A nonnational who is present in the State without permission may be issued with a proposal to deport under section 3 of the 1999 Act. In response to this, they may make representations to the Minister against the making of a deportation order and for the granting of leave to remain instead. Leave to remain provides an additional avenue for non-EU nationals to be granted permission to remain in the State.

The Department of Justice and Equality does not distinguish between leave to remain granted following a decision not to make a deportation order under section 3 of the 1999 Act for reasons relating to protection (such as in accordance with the principle of non-refoulement) or for other discretionary reasons not relating to protection (Stanley et al., 2010). ${ }^{6}$ It is currently only possible to distinguish between persons who submitted an international protection application and who were subsequently granted leave to remain and those persons who were granted

Consultation with the Department of Justice and Equality, November 2019.

Student Support Act 2011 (as amended), s 14; Student Support Regulations 2019, s 5(2). See also: SUSI, 'Nationality criteria', https://susi.ie/eligibility/nationality-criteria/.

6 The principle of non-refoulement is a core principle of international refugee and human rights law that prohibits states from returning individuals to a country where there is a real risk of them being subjected to persecution, torture, inhuman or degrading treatment or any other human rights violation (EMN, 2018). 
leave to remain not having submitted an international protection application. Between 2010 and 2018, 4,676 persons who had submitted an application for international protection were granted leave to remain, while 1,564 additional persons who had not come through the protection process were granted leave to remain following a decision not to make a deportation order.

Rights for persons granted leave to remain following a decision not to make a deportation order under section 3 of the 1999 Act are not provided for in legislation and are subject to ministerial discretion. Some applicants may get Stamp 4 permission, which entitles them to seek employment without an employment permit and to apply for social welfare, provided that all qualifying conditions are satisfied. Other applicants may get a Stamp 3 permission, which precludes holders from accessing employment or receiving social welfare (Stanley et al., 2010).

\section{PERMISSION TO REMAIN PURSUANT TO SECTION 4 OF THE IMMIGRATION ACT 2004}

The Immigration Act 2004 (the 2004 Act) regulates the entry of non-nationals to the State. Section 4 of the 2004 Act provides the Minister, or an immigration officer on his behalf, with discretion to grant a non-Irish national permission to land or be in the State and to impose conditions on such permission as he sees fit. Section 4 of the 2004 Act is a statutory mechanism that may provide a means to grant an individual permission to be or remain in the State. Representatives of the Department of Justice and Equality have confirmed that there have been instances where the Minister has granted migrants permission to remain under section 4 of the Immigration Act 2004, but that this mechanism has not been used at any time to grant permission to remain to anyone with international protection needs or who is at risk of refoulement (Stanley et al., 2010).

\section{PERMISSION TO REMAIN UNDER THE SYRIAN HUMANITARIAN ADMISSION PROGRAMME (SHAP)}

From 14 March to 30 April 2014, Ireland operated a one-off administrative family sponsorship scheme known as the Syrian Humanitarian Admission Programme (SHAP). SHAP aimed to offer temporary residence to vulnerable persons in Syria or persons who had fled from Syria to neighbouring countries and who had close family members residing in the State. SHAP beneficiaries were granted permission to remain on a temporary basis for an initial period of two years in the form of a SHAP authorisation stamp, which was renewable. A total of 119 persons were granted permission to remain in Ireland under SHAP between 2014 and 2015 (Arnold and Quinn, 2016).

Both the conditions of the SHAP residence permission and the rights to which SHAP beneficiaries are entitled are more limited than those granted to international protection beneficiaries and programme refugees. A key condition under SHAP was 
that the beneficiary should 'not become a burden on the State'. ${ }^{7}$ Sponsors are required to take full responsibility for supporting and maintaining the beneficiary for the duration of their residence in Ireland. The United Nations High Commissioner for Refugees (UNHCR) noted that the temporary nature of the permission caused challenges for persons seeking to access employment and thirdlevel education (Arnold and Quinn, 2016). 



\section{CHAPTER 1}

\section{Introduction}

\subsection{OBJECTIVES AND BACKGROUND TO THE STUDY}

This study examines the national statuses that may be granted for protection reasons in Ireland. The report focuses on national statuses with a sole basis in Irish domestic law and policy and does not examine in detail EU-harmonised statuses. The national statuses discussed in this report are diverse in terms of their policy objectives, legal basis, procedure and content. The study intends to provide an overview of the potential means of regularising the status of persons with a protection need that is not EU-harmonised.

The 1951 Convention relating to the Status of Refugees (1951 Refugee Convention) and the 1967 Protocol relating to the Status of Refugees together form the cornerstone of international protection law for persons who have been forced to flee their country due to persecution. In signing up to the 1951 Refugee Convention, Ireland, along with 167 other states worldwide, is obliged to establish procedures to identify who is a refugee and ensure those concerned are afforded the rights and protections provided under the Convention. The Convention also enshrines the customary international law principle of non-refoulement, which prohibits states from returning a person to a country where they face a real risk of being subjected to persecution, torture, inhuman or degrading treatment or any other human rights violation (EMN, 2018).

In 2001, the United Nations High Commissioner for Refugees (UNHCR) reported that a number of countries have put in place administrative or legislative mechanisms for regularising the stay of persons who are not recognised as refugees under the 1951 Refugee Convention but who cannot be returned to their country of origin. UNHCR welcomed this as a pragmatic approach to certain international protection needs, when such statuses complement the 1951 Refugee Convention. However, UNHCR expressed concern that, in the absence of harmonisation, the proliferation of national statuses had led to large differences in the treatment of persons seeking international protection (UNHCR, 2001).

In the EU context, the establishment of the Common European Asylum System (CEAS) sought to harmonise the status granted to persons seeking international protection and to ensure a minimum level of rights afforded to persons recognised as in need of international protection. The EU Qualification Directive codifies refugee status at EU level, in line with the 1951 Refugee Convention. The Directive also established the status of subsidiary protection for persons who are deemed to not fall under the scope of the 1951 Refugee Convention, but who are considered in need of protection in accordance with Member States' obligations under international human rights instruments and/or national practices. 
Nevertheless, a wide variety of non-harmonised statuses or national statuses granted to non-EU nationals for protection reasons are also in place across the EU (EMN, 2010; European Council on Refugees and Exiles, 2009). EU Member States reported that national forms of protection provide a means of responding to the protection needs of persons not eligible for international protection under the 1951 Refugee Convention and EU Qualification Directive. Some commentators have expressed concern that national forms of protection can result in the granting of discretionary and lower guarantees to beneficiaries of such statuses (France terre d'asile, 2008; Murphy, 2005). Such commentators have also highlighted that national forms of protection may represent a means of circumventing obligations set out under the 1951 Refugee Convention and EU law (France terre d'asile, 2008; Murphy, 2005).

In Ireland, the International Protection Act 2015 (the 2015 Act) gives effect to Ireland's obligations under the 1951 Refugee Convention and EU law. The 2015 Act provides that a successful international protection applicant may be granted refugee status or subsidiary protection. In addition to the two core international protection statuses, there are a number of national statuses set out in Irish law that may be granted to persons for protection reasons. Such statuses may represent a form of complementary protection for those who do not meet the definition of a refugee or subsidiary protection beneficiary but who nevertheless have a protection need.

The 2015 Act makes provision for the granting of programme refugee status to persons resettled to Ireland. In addition, permission to remain for persons who are unsuccessful in their application for international protection was introduced in section 49 of the 2015 Act. Beyond protection legislation, persons seeking protection may be granted permission to remain by way of immigration legislation. Such avenues include leave to remain following a decision not to make a deportation order under section 3 of the Immigration Act 1999 (the 1999 Act). The Minister for Justice and Equality (the Minister) has also exercised discretion to establish administrative schemes granting various statuses to persons in need of protection.

This study does not examine in detail EU-harmonised statuses - namely, refugee status, subsidiary protection and temporary protection - which have their basis in the 1951 Refugee Convention and EU legislation. Not all forms of status that exist in Ireland, and that are identified in this report, were designed with the purpose of addressing protection-related issues. However, the study intends to provide an overview of the potential means of regularising the status of persons with a protection need that is not EU-harmonised. In particular, it looks at the statuses that are, and have been, granted to resettled and relocated persons and beneficiaries of private, family and community sponsorship programmes, statuses granted to unsuccessful international protection applicants, as well as other 
statuses granted for protection reasons. In doing so, it discusses the origin and legal basis of each status, the procedure for granting each status and the entitlements afforded to status holders.

\subsubsection{Report outline}

The remainder of Chapter 1 sets out the objectives and background to the study, in addition to the study scope and methodology. The background section includes a brief overview of the harmonised protection statuses that are based in international and EU law and that have been incorporated into domestic law, in order to provide a context for the discussion of the various national statuses in this report.

Chapter 2 examines the various statuses with a basis in Irish domestic law and policy and the procedures in place for the granting of such statuses to non-EU nationals for protection-related reasons. Chapter 3 discusses the conditions that are commonly attached to the statuses, including the rights to which non-EU nationals granted each status are entitled. Targeted measures in place in relation to housing and other orientation and integration supports are also outlined.

\subsection{STUDY SCOPE AND DEFINITIONS}

This report focuses on national statuses granted to non-EU nationals for protection reasons with a sole basis in Irish domestic law and policy. EU-harmonised statuses - namely, refugee status, subsidiary protection status and temporary protection status - have their basis in the 1951 Refugee Convention and EU legislation, and are therefore outside the scope of this study. Statuses granted to stateless persons and victims of human trafficking are also outside the scope of this study.

The study covers national statuses that were granted in Ireland between 2010 and 2018 and includes any statuses that were introduced and subsequently ceased during the study period. Data on national statuses are provided for the period between 2010 and 2018. Any policy developments that took place up to and including 2019 are also covered by the study.

\subsubsection{Key terminology}

Unless specified otherwise, the definitions of terms used in this study are derived from the European Migration Network (EMN) study Comparative overview of national protection statuses (EMN, forthcoming) and the Asylum and migration glossary 6.0 (EMN, 2018).

For the purposes of this study, 'status' refers to a legal status that leads directly to the issuing of a residence permit granting a right to reside in a Member State (EMN, forthcoming). 
'Protection' is defined as a concept that encompasses all activities aimed at obtaining full respect for the rights of the individual in accordance with the letter and spirit of human rights, refugee and international humanitarian law (UNHCR, 2006).

For the purposes of this study, a 'national status granted to non-EU nationals for protection reasons' encompasses any status granted by a state to a third-country national on the basis of national provisions that are not related to international protection, as defined in the Qualification Directive 2011/95/EU, or to temporary protection as defined in the Temporary Protection Directive 2001/55/EC. Such national statuses may lie outside of the asylum procedure and related residence permits may be granted as part of (legal) migration policies (EMN, forthcoming).

'International protection' is defined by UNHCR as the actions by the international community, on the basis of international law, aimed at protecting the fundamental rights of a specific category of persons outside their countries of origin who lack the national protection of their own countries (UNHCR, 2006). In an EU context, international protection encompasses refugee status and subsidiary protection status (EMN, 2018). ${ }^{8}$ In Ireland, international protection is defined as 'status in the State either (a) as a refugee, on the basis of a refugee declaration, or (b) as a person eligible for subsidiary protection, on the basis of a subsidiary protection declaration'. ${ }^{9}$

A 'refugee' is defined as a 'person ... who, owing to a well-founded fear of being persecuted for reasons of race, religion, nationality, political opinion or membership of a particular social group, is outside his or her country of nationality and is unable or, owing to such fear, is unwilling to avail himself or herself of the protection of that country'. ${ }^{10} \mathrm{~A}$ 'person eligible for subsidiary protection' is defined as a third-country national who does not qualify as a refugee but in respect of whom substantial grounds have been shown for believing that the person concerned would face a real risk of suffering serious harm if returned to their country of origin, and who is unable, or, owing to such risk, unwilling to avail of the protection of that country. ${ }^{11}$

There are two different categories of refugee in Ireland: Convention refugee and programme refugee. A 'Convention refugee' is defined as a person recognised as a refugee by states under the criteria in Article $1 \mathrm{~A}$ of the 1951 Refugee Convention

Directive 2011/95/EU of the European Parliament and of the Council of 13 December 2011 on standards for the qualification of third-country nationals or stateless persons as beneficiaries of international protection, for a uniform status for refugees or for persons eligible for subsidiary protection, and for the content of the protection granted (recast), Article 2(a).

$9 \quad$ International Protection Act 2015, s 2(1).

10 Ibid.

11 Council Directive 2004/83/EC of 29 April 2004 on minimum standards for the qualification and status of third-country nationals or stateless persons as refugees or as persons who otherwise need international protection and the content of the protection granted, Article 2(e). 
and entitled to the enjoyment of a variety of rights under the Convention (EMN, 2018). In Ireland, a person may be recognised as a Convention refugee following the submission of an application for international protection. A 'programme refugee' is defined in the EU context as a third-country national or stateless person who, on a resettlement request from UNHCR based on their need for international protection, is transferred from a third country to a Member State, where they are permitted to reside with one of the following statuses: i) refugee status; or ii) a status that offers the same rights and benefits under national and Union law as refugee status (EMN, 2018). In Ireland, a programme refugee is defined as a person to whom permission to enter and remain in the State for resettlement, or for temporary protection, has been given by the Government or the Minister and whose name is entered in a register established and maintained by the Minister, whether or not such person is a refugee within the meaning of the definition of 'refugee'. ${ }^{12}$

A 'residence permit' is defined as any authorisation issued by the authorities of an EU Member State allowing a non-EU national to stay legally in its territory (EMN, 2018). In Ireland, non-EU nationals are required to apply for immigration permission and register with the Irish Naturalisation and Immigration Service (INIS) or Garda National Immigration Bureau (GNIB) for stays of longer than 90 days. An immigration permission is denoted by a stamp placed on the non-EU national's passport, which specifies the duration of the holder's permission to remain in the State. It may also contain details in relation to the conditions applicable. When a non-EU national registers, they are issued with a registration certificate in the form of an Irish Residence Permit. The Permit includes a description of the immigration permission and the specific stamp issued to the holder.

'Relocation' is defined in the general EU context as the transfer of international protection beneficiaries - from the EU Member State that granted the individual in question international protection to another EU Member State, where they will be granted similar protection. It also applies to the transfer of persons who have applied for international protection - from the EU Member State responsible for examining their application to another EU Member State where their applications for international protection will be examined. In the context of the EU emergency relocation programme, the term relates to the transfer of persons in clear need of international protection, as defined in Council Decisions 2015/1601 and 2016/1754, ${ }^{13}$ having applied for international protection from an EU Member State, Switzerland or Norway, which is responsible for examining their application to another EU Member State, Switzerland or Norway, where their application for international protection will be examined. 
'Resettlement' is defined in the global context as the selection and transfer of refugees from a state in which they have sought protection to a third state that has agreed to admit them as refugees with permanent residence status. In the EU context, the transfer takes place based on a request from the United Nations High Commissioner for Refugees (UNHCR) and based on the need for international protection of a third-country national or stateless person, from a third country to an EU Member State. They are permitted to reside with one of the following statuses: (i) refugee status within the meaning of Art. 2(d) of Directive 2011/95/EU; or (ii) a status that offers the same rights and benefits under national and EU law as refugee status.

There is no common and agreed definition of a 'private sponsorship scheme'. Generally, such schemes involve a transfer of responsibility from government agencies to private actors for some elements of the identification, pre-departure, reception or integration process for beneficiaries. Thus, sponsorship is best described as a way of admitting persons for humanitarian or (international) protection reasons, rather than as a separate status in itself.

\subsection{METHODOLOGY}

This report collates data and information on the practices concerning the granting of national statuses to non-EU nationals for protection reasons in Ireland. It is based on information gathered according to commonly agreed EMN study specifications for the EU-wide study, Comparative overview of national protection statuses in the EU and Norway. As with all EMN studies, a similar report was produced by other EMN National Contact Points. An EU-wide synthesis report, which will collate information from each report, will then be published (EMN, forthcoming).

Desk research was undertaken at the outset, including a review of existing policybased and academic literature. Data were obtained through correspondence with the Reporting and Analysis Unit (RAU) and Irish Refugee Protection Programme (IRPP) units within the Department of Justice and Equality. Outstanding information gaps were filled with comments from the Department of Justice and Equality ${ }^{14}$ and the Irish Refugee Council. The report was internally and externally reviewed.

\subsection{EU CONTEXT}

In October 1999, at the European Council in Tampere, the heads of state or government of the EU Member States agreed to work towards establishing the 
CEAS (Council of the European Union, 1999). During the first phase of the CEAS, the goal was to establish minimum standards with which Member States' asylum frameworks must comply in granting asylum to persons in need of protection. Among the instruments developed to harmonise legal standards was Council Directive 2004/83/EC (the 2004 Qualification Directive), which sets out minimum standards for the identification of refugees and persons in need of subsidiary protection and for ensuring that at least a minimum level of benefits is available for such persons in all Member States. ${ }^{15}$ As provided for in Protocol 21 annexed to the Treaty on the Function of the European Union, Ireland does not take part in the adoption of measures in the area of 'freedom, security and justice', including in relation to the CEAS, unless Ireland notifies the European Council of its wish to take part in the adoption and application of such measures. Ireland took part in the adoption and application of the 2004 Qualification Directive.

The Qualification Directive encompasses the two core protection statuses at EU level - refugee status and the status of beneficiary of subsidiary protection - which together are referred to as 'international protection'. Both the procedure and the content of each protection status are set out in the Directive's provisions. The Qualification Directive states it is based on the full and inclusive application of the Refugee Convention. ${ }^{16}$ Article 2(d) of the Qualification Directive defines refugee status as the recognition by a Member State of a third-country national or stateless person as a refugee. In line with the Refugee Convention, a refugee is defined in Article 2(c) of the Directive as a third-country national who, owing to a wellfounded fear of being persecuted for reasons of race, religion, nationality, political opinion or membership of a particular social group, is outside their country of nationality and who is unable or, owing to such fear, unwilling to avail himself or herself of the protection of that country, or as a stateless person who, being outside of the country of former habitual residence for the same reasons as mentioned above, is unable or, owing to such fear, unwilling to return to it.

Subsidiary protection is viewed as complementary and additional to refugee protection offered by the Refugee Convention, and it has its basis in international obligations under human rights instruments. ${ }^{17} \mathrm{~A}$ person eligible for subsidiary protection is defined as a third-country national or a stateless person who does not qualify as a refugee but in respect of whom substantial grounds have been shown for believing that the person concerned, if returned to their country of origin, would face a real risk of suffering serious harm and who is unable or, owing to such 
risk, unwilling to avail himself or herself of the protection of that country. ${ }^{18}$ Serious harm is defined as encompassing the death penalty or execution, torture or inhuman or degrading treatment or punishment, or serious and individual threat to a civilian's life or person as a consequence of indiscriminate violence in situations of armed conflict. ${ }^{19}$

In addition to the two core statuses set out in the Qualification Directive, Council Directive 2001/55/EC (the Temporary Protection Directive) provides an alternative protection mechanism to address situations of large numbers of displaced persons arriving in the EU from a specific country or region. ${ }^{20}$ Temporary protection under the Temporary Protection Directive provides for group-based protection as opposed to protection granted under the 1951 Refugee Convention by way of individualised status determination procedures. The Temporary Protection Directive also sets out the content and rights that must be granted to the holder of temporary protection. To activate the mechanism to grant temporary protection, the Council of the European Union must adopt a decision that establishes the existence of a 'mass influx of displaced persons'. To date, the Temporary Protection Directive has not been activated (Beirens et al., 2016). ${ }^{21}$ Ireland did not initially participate in the adoption of the Temporary Protection Directive in 2001. However, Ireland subsequently notified the Commission of its intention to accept the Temporary Protection Directive and the Directive was deemed to apply to Ireland on 2 October 2003. ${ }^{22}$

Despite the Qualification Directive's aims to achieve minimum common standards across EU Member States, its provisions were found to be vague and ambiguous, leading to differences in its application in practice (European Commission, 2009). Commentators noted how the Directive was the result of a compromise between EU Member States, with the effect that the Directive allowed for a number of derogations to allow states apply different standards of treatment for those with refugee status and subsidiary protection status, such as in relation to access to healthcare, travel documents, integration programmes and the labour market (Murphy, 2005). The European Council's Hague Programme stated the second phase of development of the CEAS should further develop common standards in order to establish a common asylum procedure and uniform asylum and subsidiary protection status (Council of the European Union, 2005). In response to the Hague

Ibid. Article 2(e).

Ibid. Article 15.

Council Directive 2001/55/EC of 20 July 2001 on minimum standards for giving temporary protection in the event of a mass influx of displaced persons and on measures promoting a balance of efforts between Member States in receiving such persons and bearing the consequences thereof. minimum standards for giving temporary protection in the event of a mass influx of displaced persons and on measures promoting a balance of efforts between Member States in receiving such persons and bearing the consequences thereof (2003/690/EC) ([2003] OJ L251/23), available at https://eur-lex.europa.eu/legal- 
Programme's goal to achieve uniformity of protection, the European Commission presented a green paper to identify options for the future of the CEAS. The green paper stated the second stage should achieve a higher common standard of protection and greater equality in protection across the EU. It also proposed reflection on the possibility of harmonising the status granted to categories of persons not eligible for international protection but who are protected against removal by the international refugee and human rights instruments that Member States have ratified (European Commission, 2007).

In 2008, the European Commission's policy plan on asylum and accompanying impact assessment observed that an ever-growing proportion of protection applicants were granted subsidiary protection or other kinds of protection status based on national law with lower guarantees, rather than refugee status (European Commission, 2008a, 2008b). This trend was attributed to people seeking protection for reasons not foreseen in the 1951 Refugee Convention. The Commission expressed concern that the granting of 'residual' statuses of a 'precarious nature' risked weakening the levels of protection granted and gives rise to substantial differences in procedures and content of protection across the EU, contrary to the objective of harmonising asylum policy (European Commission, 2008b). The Commission therefore highlighted the importance of paying particular attention to subsidiary and other forms of protection (European Commission, 2008a). The Commission's impact assessment noted that the introduction of categories of protection for non-removable persons was supported by NGOs during consultations on the green paper; however, it reported that this was not supported to the same extent by Member States (European Commission, 2008b).

The trends identified by the Commission in 2008 were echoed in the first EMN study on non-harmonised protection statuses in 2010. At least 22 Member States reported granting a number of non-harmonised statuses to non-EU nationals for protection reasons. Some Member States reported that national statuses had been put in place to respond to protection needs not addressed by the international and EU asylum framework, such as humanitarian protection granted in situations where an unsuccessful international protection applicant cannot be returned due to humanitarian grounds or that removal or deportation simply cannot take place. The study also found that several Member States resort to national provisions outside of the international protection system that govern the residence of all nonnationals as a mechanism to grant a form of status to persons who have a protection need but who do not meet international protection requirements. The study highlighted that the reliance on national statuses may give rise to persons being granted lower standards of protection (EMN, 2010).

In 2011, the EU adopted Directive 2011/95/EU (the 2011 (recast) Qualification Directive) to revise the 2004 Directive and to ensure a higher degree of harmonisation and better substantive and procedural standards of protection 
(European Commission, 2009). While Ireland opted into the 2004 Directive, Ireland has not opted into the 2011 (recast) Qualification Directive. A recent European Commission report found that, although the Directive has contributed to a certain extent to a higher level of approximation of the national rules, the practical application of the Directive still varies significantly among Member States. This has led to diverging practices as to the types of status granted to international protection applicants in the EU (European Commission, 2019). To achieve greater convergence in the forms of protection granted, the European Commission presented its proposals to replace the 2011 (recast) Qualification Directive with a new regulation to set uniform standards on the qualification of persons as beneficiaries of international protection in July 2016 (European Commission, 2016). The proposal is being considered at EU level, along with other legislative measures, as part of CEAS reform.

\subsubsection{Overview of trends regarding protection-related statuses in the EU}

EU Regulation 862/2007 on statistics on migration and international protection obliges Member States to provide Eurostat (the EU's statistical office) with data on first-instance and final decisions granting persons refugee status, subsidiary protection and temporary protection, in addition to decisions granting persons an 'authorisation to stay for humanitarian reasons under national law concerning international protection' ${ }^{23,24}$

The data required by Eurostat only offer a partial view of the total population of persons granted a status for protection-related needs. EU Member States are only required to provide figures on authorisations to stay that have a basis in national law concerning international protection. As previously stated, a number of statuses granted by EU Member States to persons for protection-related reasons exist independently of national law concerning international protection; these may consist of statuses grounded in legislation other than that relating to protection. Not all statuses in place in EU Member States are therefore covered by the definition of an authorisation to stay granted for humanitarian reasons and would not be captured in data reported to Eurostat. ${ }^{25}$ Data for Ireland show the number of persons granted permissions to remain under section 49 of the 2015 Act (see Section 2.2 of this report). As the 2015 Act introduced for the first time in international protection legislation permission to remain status for reasons including humanitarian considerations, Ireland only began reporting such figures on migration and international protection and repealing Council Regulation (EEC) No 311/76 on the compilation of statistics on foreign workers, Article 4(2). international protection, but who are protected against removal under the obligations that are imposed on all Member States by international refugee or human rights instruments or on the basis of principles flowing from such instruments. See: Eurostat, 'Glossary: Asylum decision', https://ec.europa.eu/eurostat/statisticsexplained/index.php/Glossary:Asylum_decision. 
to Eurostat in 2017, following the coming into force of the 2015 Act on 31

December 2016.

FIGURE 1.1 TOTAL FIRST-INSTANCE POSITIVE DECISIONS IN EU MEMBER STATES, INCLUDING REFUGEE STATUS, SUBSIDIARY PROTECTION AND AUTHORISATIONS TO STAY FOR HUMANITARIAN REASONS, 2010-2018

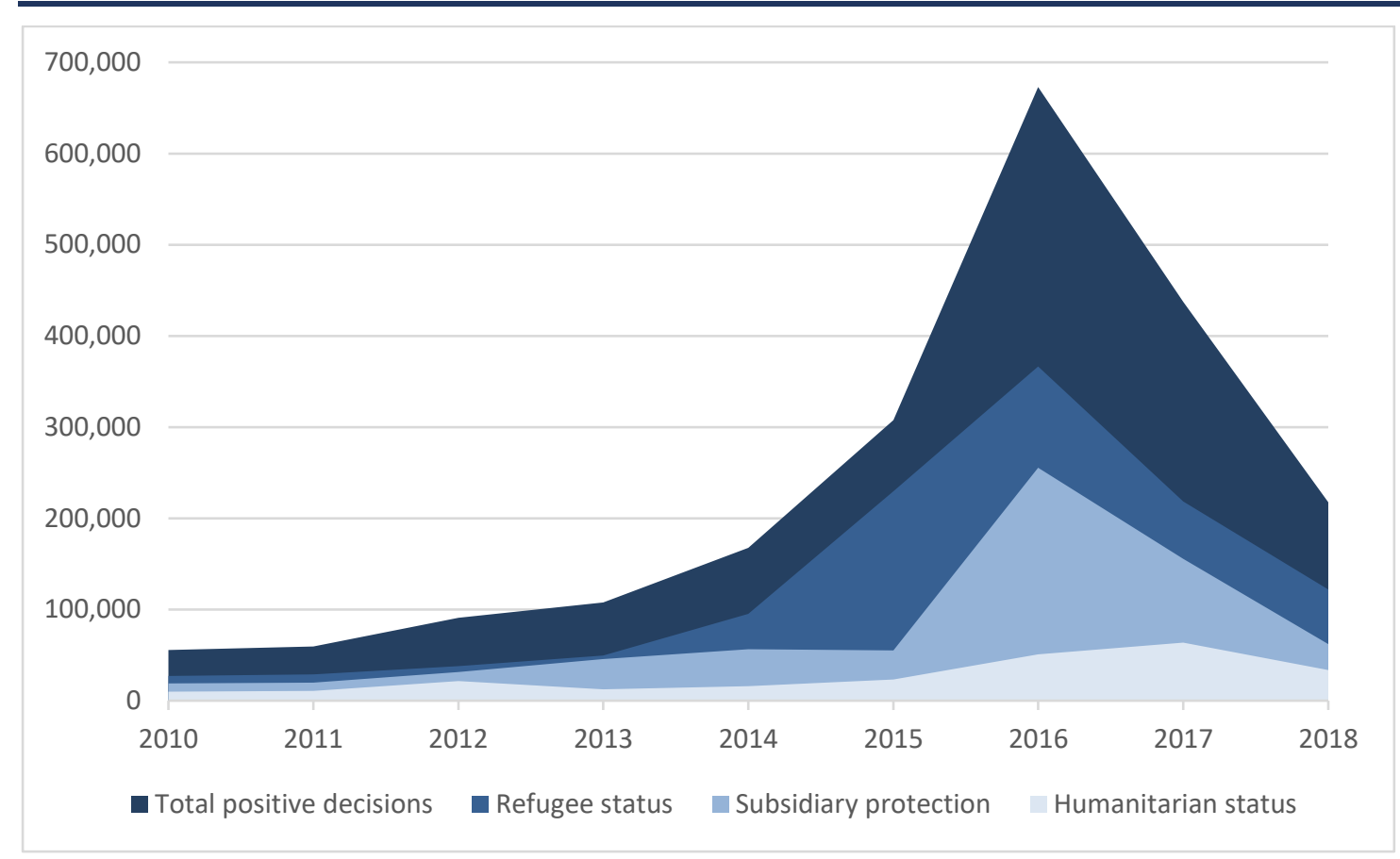

Sources: Eurostat, 'First instance decisions on applications by citizenship, age and sex, annual aggregated data (rounded) [migr_asydcfsta]', http://appsso.eurostat.ec.europa.eu/nui/show.do?dataset=migr_asydcfsta\&lang=en.

Note: $\quad$ Eurostat figures are rounded to the nearest five.

Figure 1.1 shows that the number of reported positive decisions at first instance increased gradually from 55,575 in 2010 to 167,385 in 2014, followed by a significant increase to 307,650 in 2015 . The number of persons granted a protection status then more than doubled in 2016 , to reach a peak of 672,890 , following the large increase in asylum applications lodged in the EU in 2015. Figures subsequently decreased to 437,555 in 2017 . The number of granted authorisations to stay for humanitarian reasons fluctuated between 2010 and 2018. Some 9,790 authorisations were granted in 2010, accounting for 18 per cent of all positive decisions issued in the EU Member States in the same year. The number doubled to 21,630 in 2012, representing 24 per cent of all reported positive decisions in 2012. Following a decrease in 2013 to 12,505, the granting of authorisations grew year on year to 2017 , when they reached a peak of $63,650-15$ per cent of all reported positive decisions.

In 2018, over 582,000 first-instance decisions on an application for international protection were issued in EU Member States, of which 217,405 were positive. Among the positive decisions were 122,070 on refugee status, 61,900 on subsidiary protection and 33,435 on authorisation to stay for humanitarian reasons. Almost 35 per cent of all positive decisions were issued by Germany, 15 per cent by France and 14 per cent by Italy. Of the 33,435 authorisations to stay granted for 
humanitarian reasons, 60 per cent were granted by Italy and 29 per cent by Germany.

The largest number of positive refugee status decisions in 2018 were granted to nationals of Syria, followed by Iraq, Afghanistan, Eritrea and Iran. The largest number of positive subsidiary protection status decisions in 2018 were granted to nationals of Syria, followed by Afghanistan, Iraq, Eritrea and Somalia. Table 1.1 shows that the largest number of positive decisions on authorisations for humanitarian reasons in 2018 were granted to nationals of Afghanistan, Nigeria, Bangladesh, The Gambia and Iraq (in that order).

Table 1.1 also shows that a large proportion of the growth in number of authorisations to stay for humanitarian reasons was due to the increase in nationals of Afghanistan granted such authorisations. The number of authorisations to stay for humanitarian reasons granted to nationals of Afghanistan increased from 1,660 in 2015 to 20,780 in 2016. This increased further to 27,595 in 2017 and decreased again to 4,600 in 2018. 
TABLE 1.1 TOP FIVE COUNTRIES OF ORIGIN OF PERSONS GRANTED AUTHORISATIONS TO STAY FOR HUMANITARIAN REASONS AT FIRST INSTANCE, 2010-2018

\begin{tabular}{|c|c|c|c|c|c|c|c|}
\hline & $\begin{array}{c}\text { Nationality } \\
1\end{array}$ & $\begin{array}{c}\text { Nationality } \\
2\end{array}$ & $\begin{array}{c}\text { Nationality } \\
\mathbf{3}\end{array}$ & $\begin{array}{c}\text { Nationality } \\
4\end{array}$ & Nationality 5 & Other & Total \\
\hline \multirow[t]{2}{*}{2010} & Afghanistan & Somalia & Iraq & Iran & Nigeria & & \\
\hline & 2,525 & 1,820 & 665 & 335 & 265 & 4,180 & 9,790 \\
\hline \multirow[t]{2}{*}{2011} & Afghanistan & Somalia & Nigeria & Iraq & Iran & & \\
\hline & 2,840 & 600 & 585 & 575 & 360 & 5,565 & 10,525 \\
\hline \multirow[t]{2}{*}{2012} & Nigeria & Ghana & Afghanistan & Bangladesh & Cote d'Ivoire & & \\
\hline & 4,930 & 2,920 & 2,155 & 1,025 & 1,000 & 9,600 & 21,630 \\
\hline \multirow[t]{2}{*}{2013} & Afghanistan & Nigeria & Somalia & Pakistan & Ghana & & \\
\hline & 2,300 & 1,120 & 990 & 630 & 495 & 6,970 & 12,505 \\
\hline \multirow[t]{2}{*}{2014} & Afghanistan & Mali & Nigeria & Pakistan & The Gambia & & \\
\hline & 1,955 & 1,690 & 1,490 & 1,195 & 1,080 & 8,300 & 15,710 \\
\hline \multirow[t]{2}{*}{2015} & Nigeria & The Gambia & Mali & Afghanistan & Pakistan & & \\
\hline & 2,665 & 2,575 & 1,940 & 1,660 & 1,490 & 13,260 & 23,590 \\
\hline \multirow[t]{2}{*}{2016} & Afghanistan & Nigeria & Syria & The Gambia & Somalia & & \\
\hline & 20,780 & 3,520 & 3,160 & 2,380 & 2,090 & 19,050 & 50,980 \\
\hline \multirow[t]{2}{*}{2017} & Afghanistan & Nigeria & The Gambia & Somalia & Iraq & & \\
\hline & 27,595 & 5,595 & 2,615 & 2,285 & 2,250 & 23,310 & 63,650 \\
\hline \multirow[t]{2}{*}{2018} & Afghanistan & Nigeria & Bangladesh & The Gambia & Iraq & & \\
\hline & 4,600 & 4,400 & 2,665 & 2,310 & 2,035 & 17,425 & 33,435 \\
\hline
\end{tabular}

Source: Eurostat, 'First instance decisions on applications by citizenship, age and sex, annual aggregated data (rounded) [migr_asydcfsta]', http://appsso.eurostat.ec.europa.eu/nui/show.do?dataset=migr_asydcfsta\&lang=en.

Note: $\quad$ Eurostat figures are rounded to the nearest five.

Figure 1.2 shows the number of total positive final decisions on refugee status, subsidiary protection and authorisations to stay granted for humanitarian reasons. Final decisions consist of those taken by administrative or judicial bodies on appeal or review. Total final positive decisions increased significantly between 2015 and 2018. In particular, the number of authorisations to stay for humanitarian reasons that were granted at final instance grew from 3,650 in 2015 to 35,800 in 2018, representing one-third of all positive decisions issued at final instance in 2018.

The largest number of final positive decisions on refugee status in 2018 were granted to nationals of Syria, followed by Afghanistan, Iran, Iraq and Eritrea. ${ }^{26}$ The largest number of final positive decisions on subsidiary protection status in 2018 were granted to nationals of Syria, followed by Iraq, Afghanistan, Nigeria and Eritrea. ${ }^{27}$ The largest number of final positive decisions on authorisations to stay for humanitarian reasons in 2018 were in respect of nationals from Afghanistan, Nigeria, Pakistan, Bangladesh, The Gambia and Senegal. ${ }^{28}$

26 Eurostat, 'First instance decisions on applications by citizenship, age and sex Annual aggregated data (rounded) [migr_asydcfsta]', http://appsso.eurostat.ec.europa.eu/nui/show.do?dataset=migr_asydcfsta\&lang=en. 
FIGURE 1.2 TOTAL FINAL POSITIVE DECISIONS IN EU MEMBER STATES, INCLUDING REFUGEE STATUS, SUBSIDIARY PROTECTION AND AUTHORISATIONS TO STAY FOR HUMANITARIAN REASONS, 2010-2018

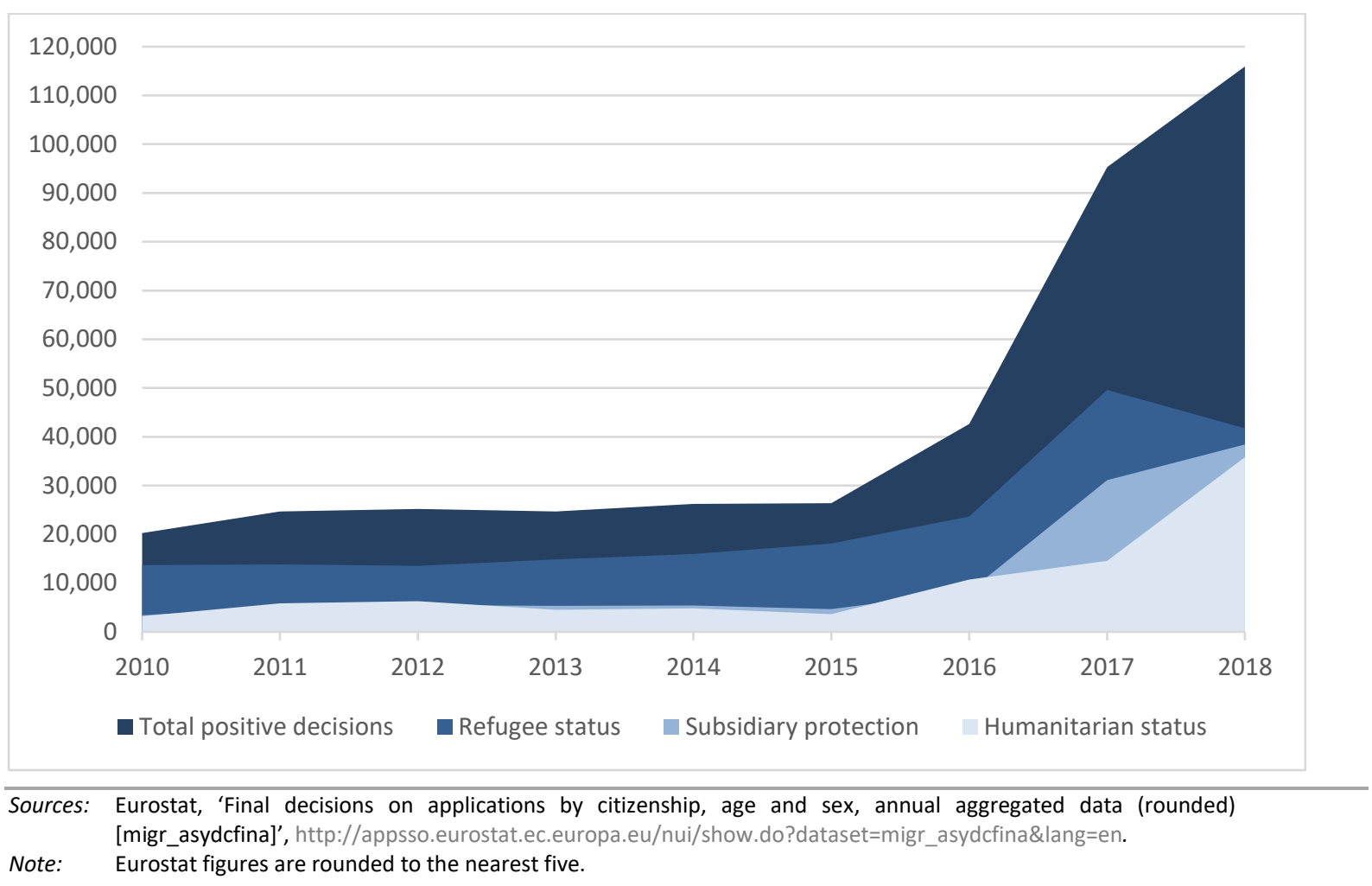

Available data on statuses in other EU Member States that have a basis in national law and policy were gathered in the first EMN study on non-harmonised protection statuses in 2010 (EMN, 2010). It is expected that data on statuses granted for protection reasons in other EU Member States, where available, will be presented in the EMN's forthcoming EU-level synthesis report, Comparative overview of national protection statuses (EMN, forthcoming).

\section{$1.5 \quad$ IRISH CONTEXT}

The Irish State's inherent power to control the entry and presence of non-Irish nationals in the State is vested in the Government pursuant to Article 28.2 of the Constitution of Ireland. Over the last two decades, the Irish legislature has introduced various measures to regulate the immigration of non-Irish nationals and international protection, from which arise a number of national statuses that may be granted to non-EU nationals for protection reasons.

The principal legislative acts governing immigration to Ireland are the Immigration Acts 1999, 2003 and 2004. Immigration legislation provides the broad framework in which the Minister must act and affords wide discretion to the Minister to control the entry and presence of non-Irish nationals. The Immigration Act 2004 (the 2004 Act) provides the statutory basis for granting permission to non-EU nationals to reside in the State. Section 5 of the 2004 Act provides, inter alia, that 
no non-Irish national may be in the State other than in accordance with the terms of, inter alia, permission given under the Act. Section 4 of the 2004 Act enables permissions to be given by immigration officers, on behalf of the Minister, to nonIrish nationals authorising them to land or be in the State. Section 4(6) entitles immigration officers to attach conditions to permissions granted, such as relating to duration of stay and engagement in employment.

Prior to the harmonisation of international protection law at EU level, Ireland introduced the Refugee Act 1996 (the 1996 Act), which came into force in 2000, and which gave effect to Ireland's obligations under the 1951 Refugee Convention in domestic law for the first time. The 1996 Act set out the definition of a refugee in line with the Refugee Convention and the process for lodging and determining an asylum application. Prior to the adoption by the EU of the 2004 Qualification Directive, there was no statutory scheme to grant protection to persons refused a refugee status declaration. Persons seeking protection and refused refugee status typically made representations to the Minister against the making of a deportation order, under section 3 of the Immigration Act 1999, as amended, in order to be granted permission to remain. However, in October 2006, the European Communities (Eligibility for Protection) Regulations 2006 (S.I. No. 518 of 2006) were adopted to give effect to the provisions of the 2004 Qualification Directive, and in particular subsidiary protection status, in Irish law. Persons refused refugee and subsidiary protection status still however relied on section 3 of the 1999 Act (see Section 2.4 of this report).

The Irish asylum framework was subsequently overhauled with the enactment of the International Protection Act 2015 (the 2015 Act), which came into effect on 31 December 2016, repealing and replacing the 1996 Act. The 2015 Act embedded the EU-harmonised statuses of (Convention) refugee and subsidiary protection in primary legislation, thereby giving effect to the 2004 Directive. In addition, the 2015 Act introduced a permission to remain status (under section 49) for international protection applicants who receive a negative decision on refugee status and subsidiary protection. The 2015 Act also introduced a new single procedure for assessing applications for international protection (refugee status and subsidiary protection status) and permission to remain, whereby eligibility for each status is considered, and a decision provided on all three simultaneously.

\subsubsection{Non-EU harmonised national statuses that may be granted for protection reasons}

This study does not examine EU-harmonised statuses, namely refugee status, subsidiary protection or temporary protection, which have their basis in the 1951 Refugee Convention and EU law. Not all forms of status that exist in Ireland, and that are discussed in this report, were designed with the purpose of addressing protection-related issues. However, this section introduces the potential statuses 
that are not EU-harmonised and that may be granted to persons with a protection need.

\section{Programme refugee status}

Section 59 of the 2015 Act provides for the granting of programme refugee status to refugees that are resettled to Ireland. The status was first introduced in the 1996 Act to provide clarity on the legal status granted to refugees resettled to Ireland since the 1950s (see Section 2.1 of this report). ${ }^{29}$

\section{Permission to remain under section 49 of the 2015 Act}

As stated above, the status of permission to remain for persons who receive a negative decision on an international protection application was introduced in the 2015 Act. Section 49 states that, where an applicant receives a negative decision on an international protection application, the Minister must consider whether to give the applicant permission to remain in the State (see Section 2.2 of this report).

\section{Leave to remain following a decision not to make a deportation order under section 3 of the Immigration Act 1999}

Leave to remain following a decision not to make a deportation order under section 3 of the Immigration Act 1999 (the 1999 Act) provides an additional avenue for non-EU nationals to be granted permission to remain in the State (see Section 2.4 of this report).

\section{Permission to remain under section 50(4) of the 2015 Act (Prohibition of refoulement)}

Section 50(4) of the 2015 Act makes provision on a statutory basis for the granting of a residency permission to persons who have received a negative decision on an application for international protection and permission to remain but who cannot be returned (Stanley, 2017).

\section{Permission to remain under section 4 of the Immigration Act 2004 (Permission to land or be in the State)}

As stated above, section 4 of the 2004 Act provides the Minister for Justice and Equality, or an immigration officer on his behalf, with discretion to grant a nonIrish national with permission to land or be in the State and to impose conditions on such permission as they see fit. Section 4 of the Immigration Act 2004 is a statutory mechanism that may provide a means to grant an individual permission to be or remain in the State (see Section 2.5 of this report).

\section{Syrian Humanitarian Admission Programme (SHAP)}

From 14 March to 30 April 2014, Ireland operated a one-off administrative family sponsorship scheme known as the Syrian Humanitarian Admission Programme 
(SHAP). SHAP aimed to offer temporary residence to vulnerable persons in Syria or persons who had fled from Syria to neighbouring countries and who had close family members residing in the State. SHAP beneficiaries were granted permission to remain on a temporary basis for a period of two years in the form of a SHAP authorisation stamp, which was renewable (see Section 2.6 of this report).

\subsubsection{Overview of trends regarding protection-related statuses in Ireland}

\section{Data collection}

There is currently no comprehensive data source that shows the number of people in Ireland who have, or have in the past held, a status for protection reasons.

Administrative data on immigration and international protection are gathered by various divisions of the Department of Justice and Equality and are processed by the Reporting and Analysis Unit (RAU).

The International Protection Office (IPO) is responsible for processing applications for international protection and permission to remain under the 2015 Act. IPO gathers figures on the number of persons granted international protection and permission to remain under section 49 of the 2015 Act. These include persons who arrived in Ireland under the relocation strand of the IRPP. Prior to the transfer of responsibility for the investigation of applications for international protection to IPO in 2016, the now abolished Office of the Refugee Applications Commissioner (ORAC) published annual data on the number of decisions granting refugee status to international protection applicants. ${ }^{30}$ In contrast to the practices of its predecessor, IPO no longer publishes annual data on grants of Convention refugee status. Currently, IPO produces monthly data reports on the number of applications for international protection only. However, annual figures on firstinstance and final positive decisions on Convention refugee status and subsidiary protection reported by Ireland have been published by Eurostat since $2008 .{ }^{31}$ The number of persons granted permission to remain in Ireland under section 49 of the 2015 Act have also been reported to Eurostat as 'authorisations to stay for humanitarian reasons' (see Section 1.4.1 of this report) since 2017, following the coming into force of the 2015 Act on 31 December 2016.

For the purpose of the study, the Department of Justice and Equality provided figures on the number of persons granted permission to remain following a decision not to make a deportation order under section 3 of the 1999 Act. These figures are disaggregated according to whether or not the individuals in question

See: ORAC, 'Statistics', http://www.orac.ie/website/orac/oracwebsite.nsf/page/orac-stats-en. Eurostat figures are rounded to the nearest five. See: Eurostat, 'First instance decisions on applications by citizenship, age and sex Annual aggregated data (rounded) [migr_asydcfsta]',

http://appsso.eurostat.ec.europa.eu/nui/show.do?dataset=migr_asydcfsta\&lang=en. 
came through the international protection process. Figures are not, however, disaggregated according to the grounds on which permission to remain following a decision not to make a deportation order under section 3 of the 1999 Act was granted. ${ }^{32}$

Figures for persons granted programme refugee status in Ireland were provided by the IRPP unit of the Department of Justice and Equality. These include figures for persons resettled to Ireland under government-led resettlement programmes, unaccompanied minors arriving through the Calais Special Project and persons granted programme refugee status on arrival in Ireland under the Community Sponsorship Ireland (CSI) initiative. Comprehensive data are reported on the IRPP section of the Department of Justice and Equality website for persons resettled to Ireland under the Irish Refugee Resettlement Programme (IRRP) prior to 2016; data on persons resettled under the resettlement strand of the IRPP since its establishment in 2015 have been reported sporadically on the Department of Justice and Equality website.

Updated data on grants of international protection and other statuses may be provided by way of response to parliamentary questions on an ad hoc basis. See Fahey et al. (2019) for more information on administrative data on immigration and international protection.

\section{Recent trends}

This section presents the data available on grants of various statuses included in this study. Table 1.2 shows data on first-instance grants and grants on appeal of Convention refugee status, subsidiary protection and permission to remain under section 49 of the 2015 Act, from 2010 to 2018. It also includes the number of persons granted programme refugee status, persons granted leave to remain under section 3 of the 1999 Act after having gone through the international protection process and persons granted permission under SHAP. 
TABLE 1.2 PERSONS GRANTED PROGRAMME REFUGEE STATUS, CONVENTION REFUGEE STATUS, SUBSIDIARY PROTECTION, PERMISSION TO REMAIN UNDER SECTION 49 OF THE 2015 ACT AND PERSONS WHO PREVIOUSLY SUBMITTED AN INTERNATONAL PROTECTION APPLICATION GRANTED LEAVE TO REMAIN FOLLOWING A DECISION NOT TO DEPORT UNDER THE 1999 ACT, 2010-2018

\begin{tabular}{|c|c|c|c|c|c|c|c|c|c|}
\hline \multirow{2}{*}{ Status } & \multirow{2}{*}{$\begin{array}{l}\text { Programme } \\
\text { refugee }\end{array}$} & \multicolumn{3}{|c|}{ Granted at first instance } & \multicolumn{2}{|c|}{$\begin{array}{l}\text { Granted on appeal of first- } \\
\text { instance decision }\end{array}$} & \multirow{2}{*}{$\begin{array}{l}\text { Granted on } \\
\text { review of first- } \\
\text { instance } \\
\text { decision } \\
\text { Permission to } \\
\text { remain s } 49 \\
2015 \text { Act }\end{array}$} & \multirow{2}{*}{$\begin{array}{c}\text { Leave to } \\
\text { remain } \\
\text { s } 31999 \\
\text { Act }\end{array}$} & \multirow{2}{*}{$\begin{array}{l}\text { SHAP } \\
\text { stamp }\end{array}$} \\
\hline & & $\begin{array}{l}\text { Convention } \\
\text { refugee }\end{array}$ & $\begin{array}{l}\text { Subsidiary } \\
\text { protection }\end{array}$ & $\begin{array}{l}\text { Permission to } \\
\text { remain s } 49 \\
2015 \text { Act }\end{array}$ & $\begin{array}{l}\text { Convention } \\
\text { refugee }\end{array}$ & $\begin{array}{l}\text { Subsidiary } \\
\text { protection }\end{array}$ & & & \\
\hline 2010 & 20 & 24 & $<5$ & - & 130 & - & - & 165 & - \\
\hline 2011 & 45 & 61 & 13 & - & 75 & - & - & 749 & - \\
\hline 2012 & 49 & 67 & 28 & - & 45 & - & - & 406 & - \\
\hline 2013 & 86 & 128 & 31 & - & 55 & - & - & 642 & - \\
\hline 2014 & 96 & 132 & 251 & - & 90 & 5 & - & 647 & 114 \\
\hline 2015 & 176 & 152 & 181 & - & 180 & 40 & - & 1,210 & 5 \\
\hline 2016 & 356 & 443 & 41 & - & 205 & 100 & - & 468 & - \\
\hline 2017 & 303 & 640 & 50 & 72 & 30 & 50 & - & 169 & - \\
\hline 2018 & 349 & 630 & 180 & 195 & 185 & 45 & 40 & 220 & - \\
\hline Total & 1,480 & 2,277 & 775 & 267 & 995 & 240 & 40 & 4,676 & 119 \\
\hline
\end{tabular}

Source: Correspondence with the IRPP unit, Department of Justice and Equality, May 2019; Correspondence with RAU, Department of Justice and Equality, May 2019; ORAC, 2011, 2012, 2013, 2014, 2015, 2016, 2017; Joyce and Gusciute, 2015; Joyce and Whelan, 2015; Sheridan and Whelan, 2016; Arnold and Quinn, 2016; Sheridan, 2017a; Eurostat, 'First instance decisions on applications by citizenship, age and sex Annual aggregated data (rounded) [migr_asydcfsta]', http://appsso.eurostat.ec.europa.eu/nui/show.do?dataset=migr_asydcfsta\&lang=en.

Notes: $\quad$ Eurostat figures are used for Convention refugee status and subsidiary protection status granted at first instance in 2017 and 2018 and Convention refugee status and subsidiary protection status granted on appeal, and permission to remain under section 49 of the 2015 Act granted on review, for all years. Eurostat data are rounded to the nearest five. National figures under 5 are reported as $<5$. Data may be granted for reasons thare not protection-related. Programme refugees include resettled persons between 2010 and 2018 ; persons relocat to lreland from refugee status are included in figures for 2011, 2012 and 2013; unaccompanied children admitted to Ireland under the Calais Special Project are included in figures for 2017 and 2018 ; persons admitted to Ireland through community sponsorship are included in 2018. 


\section{Persons granted international protection at first instance}

Table 1.2 shows that the number of persons granted Convention refugee status at first instance increased from 24 in 2010 to 630 in 2018. The top five countries of origin of persons granted refugee status during this period were Syria, followed by Iraq, Libya, Afghanistan and Iran. ${ }^{33}$

The number of persons granted subsidiary protection grew from five in 2010 to 270 in 2014. The number of persons recognised as subsidiary protection beneficiaries decreased to 40 in 2016; however, this had increased again to 180 by 2018. The top five countries of origin of persons granted subsidiary protection between 2010 and 2018 were Afghanistan, Democratic Republic of the Congo, Somalia, Pakistan and Iraq. ${ }^{34}$

\section{Persons granted permission to remain under section 49 of the 2015 Act at first instance}

As the 2015 Act came into effect on 31 December 2016, data on permission to remain under section 49 of the 2015 Act have been reported from 2017. Table 1.2 shows that 72 people were granted permission to remain under the 2015 Act in 2017, while 196 were granted this in 2018 (Sheridan, 2019). ${ }^{35}$ In addition to spontaneous applicants for international protection, persons arriving through the relocation strand of the IRPP and search and rescue missions may be granted permission to remain under section 49 of the 2015 Act, following submission of an application for international protection (see Section 2.2.1 of this report). Of the 72 people granted permission to remain under section 49 of the 2015 Act in 2017, four were applicants for protection relocated to Ireland under the IRPP. ${ }^{36}$

\section{Final decisions on international protection and permission to remain under the 2015 Act}

Data gathered by INIS on final decisions relating to international protection and permission to remain under section 49 of the 2015 Act are published by Eurostat (rounded to the nearest five). Table 1.2 shows that 995 people were granted Convention refugee status on appeal of a first-instance decision between 2010 and $2018 .{ }^{37}$

In November 2013, the then Refugee Appeals Tribunal was tasked with hearing appeals of a negative decision on subsidiary protection, following the enactment of the European Union (Subsidiary Protection) Regulations 2013 (S.I. No. 426 of [migr_asydcfsta]', http://appsso.eurostat.ec.europa.eu/nui/show.do?dataset=migr_asydcfsta\&lang=en. Eurostat, 'First instance decisions on applications by citizenship, age and sex Annual aggregated data (rounded) [migr_asydcfsta]', http://appsso.eurostat.ec.europa.eu/nui/show.do?dataset=migr_asydcfsta\&lang=en. Correspondence with RAU, Department of Justice and Equality, May 2019.

Correspondence with RAU, Department of Justice and Equality, May 2019.

Eurostat figures state that 20 people were granted Convention refugee status at final instance in 2013 . This was followed by 20 in 2014, 45 in 2015, 45 in 2016, five in 2017 and 50 in 2018 (figures are rounded). See: Eurostat, 'Final decisions on applications by citizenship, age and sex Annual data (rounded) [migr_asydcfina]', http://appsso.eurostat.ec.europa.eu/nui/show.do?dataset=migr_asydcfina\&lang=en. 
2013). Previously, an application for subsidiary protection was assessed by officials within the Department of Justice on behalf of the Minister, rather than ORAC (now IPO), and an applicant had no right of appeal in the case of a negative decision. The Tribunal received no subsidiary protection appeals by end 2013 (Refugee Appeals Tribunal, 2014); thus, data on positive decisions granting subsidiary protection on appeal are only reported from 2014. In 2014, five persons were granted subsidiary protection status on appeal. This grew to 40 in 2015 and reached a peak of 100 in 2016. Numbers decreased to 50 in 2017 and 40 in 2018.

Eurostat figures show 40 persons were granted permission to remain under the 2015 Act in 2018, following a review of an initial decision to refuse permission to remain.

\section{Programme refugees}

A total of 1,480 persons were granted programme refugee status between 2010 and 2018. ${ }^{38}$ As shown in Table 1.2, the period between 2010 and 2018 saw a gradual increase in the number of persons granted programme refugee status annually, in large part as a result of Ireland's increased resettlement commitments under the IRPP and ad hoc schemes established in recent years to admit persons to Ireland and grant them programme refugee status. The majority of persons granted programme refugee status each year are refugees resettled to Ireland. Persons who have arrived in Ireland through IHAP and the CSI, as well as most unaccompanied children arriving under the Calais Special Project, have also been granted programme refugee status.

\section{Resettled persons}

The majority of persons granted programme refugee status each year are refugees resettled to Ireland under the IRRP, which since 2015 operates under the aegis of the IRPP (see Section 2.1 of this report). When the Government established a national resettlement programme in 2000, Ireland agreed to accept up to ten persons, together with members of their family for resettlement per year, which would amount to resettling approximately 40 persons in total annually (Kinlen, 2011). ${ }^{39}$ In 2005, the Minister announced a government decision to increase the annual quota to 200 resettled refugees. ${ }^{40}$ That year, 115 persons were resettled in Ireland. The figure grew to 184 in 2006, but subsequently decreased to 104 in 2007 and 101 in 2008. While the number of persons resettled grew to 192 in 2009, subsequent years saw a significant drop in the number of those resettled, a trend partly attributed to economic difficulties in Ireland at the time (Papadopoulou et

Correspondence with the IRPP unit, Department of Justice and Equality, May 2019.

Department of Justice and Equality, 'Minister McDowell greets Iranian Kurdish refugees in Mayo', press release, 10 July 2006, http://www.inis.gov.ie/en/INIS/Pages/PR07000140.

40 Department of Justice and Equality, 'Minister Announces increase in refugee resettlement quota', press release, 8 June 2005, http://www.inis.gov.ie/en/INIS/Pages/SP07000170. 
al., 2013). Ireland resettled 20 people in 2010 and 35 in 2011; of the 35, 25 were resettled under the IRRP. In 2012, 39 persons were resettled, followed by 76 in 2013 and 96 in $2014 .{ }^{41}$

In September 2015, the Government established the IRPP in which it committed to accepting up to 4,000 persons through EU relocation and resettlement. Under the resettlement strand, the Government committed to resettling 520 persons in Ireland from Lebanon. ${ }^{42}$ In line with commitments made, the number of persons resettled reached 176 in 2015 and grew to 356 in 2016. ${ }^{43}$ By the end of 2016, 519 persons out of the original commitment of 520 had arrived in Ireland (INIS, 2017a). The number of persons resettled in Ireland and granted programme refugee status slightly decreased to 273 in 2017, followed by an increase in 2018 to $335 .{ }^{44}$ Table 1.3 presents the number of refugees resettled to Ireland annually through the IRRP and IRPP between 2000 and 2018. 


\begin{tabular}{|c|c|}
\hline Year & Total resettled programme refugees \\
\hline 2000 & 35 \\
\hline 2001 & 52 \\
\hline 2002 & 28 \\
\hline 2003 & 50 \\
\hline 2004 & 58 \\
\hline 2005 & 115 \\
\hline 2006 & 184 \\
\hline 2007 & 104 \\
\hline 2008 & 101 \\
\hline 2009 & 192 \\
\hline 2010 & 20 \\
\hline 2011 & 25 \\
\hline 2012 & 39 \\
\hline 2013 & 76 \\
\hline 2014 & 96 \\
\hline 2015 & 176 \\
\hline 2016 & 356 \\
\hline 2017 & 273 \\
\hline 2018 & 335 \\
\hline Total & 2,315 \\
\hline
\end{tabular}

Source: Correspondence with RAU, Department of Justice and Equality, May 2019; Office for the Promotion of Migrant Integration, 'Refugee resettlement statistics 2000-2016 (pre-IRPP)',

http://www.integration.ie/en/isec/pages/refugee_resettlement_stats_pre-irpp.

Note: Data exclude relocated programme refugees from Malta in 2007, 2011, 2012 and 2013 (see 'relocated programme refugees' below and Section 2.1.6 of this report).

\section{Relocated programme refugees}

The figures on persons granted programme refugee status in Table 1.2 include 30 programme refugees relocated to Ireland from Malta between 2011 and 2013 (see Section 2.1.6 of this report).

\section{Unaccompanied children}

The number of persons granted programme refugee status in 2017 and 2018 includes 39 of the 41 unaccompanied children who were admitted to Ireland under the Calais Special Project, established in November 2016 (see Section 2.1.5 of this report). ${ }^{45}$

\section{Community Sponsorship Ireland (CSI)}

Included in programme refugee grants in 2018 are persons resettled in Ireland under CSI. The pilot phase of CSI was officially launched by the Government in March 2019. CSI consists of community organisations assuming responsibility for providing a range of integration supports to a refugee family, offering an 
alternative form of resettlement to that provided under the IRRP. The referral of refugees for resettlement under CSI is carried out through existing procedures in place for the government-led IRRP (see Section 2.1.4). The Government stated it expected that up to ten families ( 50 refugees in total) would arrive during the pilot phase by October 2019 (Department of Justice and Equality, 2019a). ${ }^{46}$ The first Syrian family arrived in December 2018. ${ }^{47}$ As of November 2019, five Syrian families (17 refugees in total) have been resettled in Ireland under the CSI scheme. ${ }^{48}$ On 15 November 2019, the Government officially launched the CSI scheme as a national programme. ${ }^{49}$

\section{IRPP Humanitarian Admission Programme (IHAP)}

In November 2017, the Minister announced the introduction of IHAP in order to deliver on the Government's commitment to admit 4,000 persons to Ireland under the IRPP. ${ }^{50}$ IHAP was established to provide humanitarian admission to 530 eligible family members of Irish citizens and those with international protection and programme refugee status. Persons accepted to Ireland under IHAP are granted programme refugee status.

IHAP consisted of two rounds of calls for persons to propose eligible family members for consideration; the first call ran from 14 May to 30 June 2018, while a second call ran from 20 December 2018 to 8 February 2019. The first call resulted in a total of 101 proposals being granted in respect of 171 beneficiaries to be resettled in Ireland. ${ }^{51}$ As of 4 November 2019, at least 110 beneficiaries had arrived in the State..$^{52}$ In addition, 278 persons have been granted permission under the second call. A further 182 proposals, in respect of 356 beneficiaries, are still to be processed. ${ }^{53}$

\section{Persons granted leave to remain following a decision not to make a deportation order under section 3 of the 1999 Act}

As stated above, INIS does not distinguish between leave to remain granted following a decision not to make a deportation order under section 3 of the 1999 Act for reasons relating to protection (such as against refoulement) and leave to remain granted for other discretionary reasons not relating to protection (Stanley et al., 2010). It is currently only possible to distinguish between persons who submitted an international protection application and who were subsequently

Department of Justice and Equality, 'Ministers Flanagan and Stanton meet UN High Commissioner for Refugees', press release, 11 July 2019, http://www.justice.ie/en/JELR/Pages/PR19000189. Correspondence with RAU, Department of Justice and Equality, May 2019.

Department of Justice and Equality, 'Minister Stanton officially launches Refugee Community Sponsorship Ireland', press release, 15 November 2019, http://www.justice.ie/en/JELR/Pages/PR19000282. Ibid.

Department of Justice and Equality, 'Ministers Flanagan and Stanton announce opening of the new humanitarian admissions programme', press release, 12 May 2018, http://www.justice.ie/en/JELR/Pages/PR18000149. Consultation with the Department of Justice and Equality, November 2019. Consultation with the Department of Justice and Equality, November 2019. Consultation with the Department of Justice and Equality, November 2019. 
granted leave to remain and those persons who were granted leave to remain, not having submitted an international protection application.

Figure 1.3 shows that the majority of grants of leave to remain under section 3 of the 1999 Act over the period 2010-2018 were made in respect of persons who had previously made an application for international protection. Between 2010 and $2018,4,676$ persons who had submitted an application for international protection were granted leave to remain, in contrast with 1,564 other persons who had not come through the protection process and who were granted leave to remain following a decision not to make a deportation order.

FIGURE 1.3 PERSONS GRANTED LEAVE TO REMAIN FOLLOWING A DECISION NOT TO MAKE A DEPORTATION ORDER UNDER SECTION 3 OF THE IMMIGRATION ACT 1999, 2010-2018

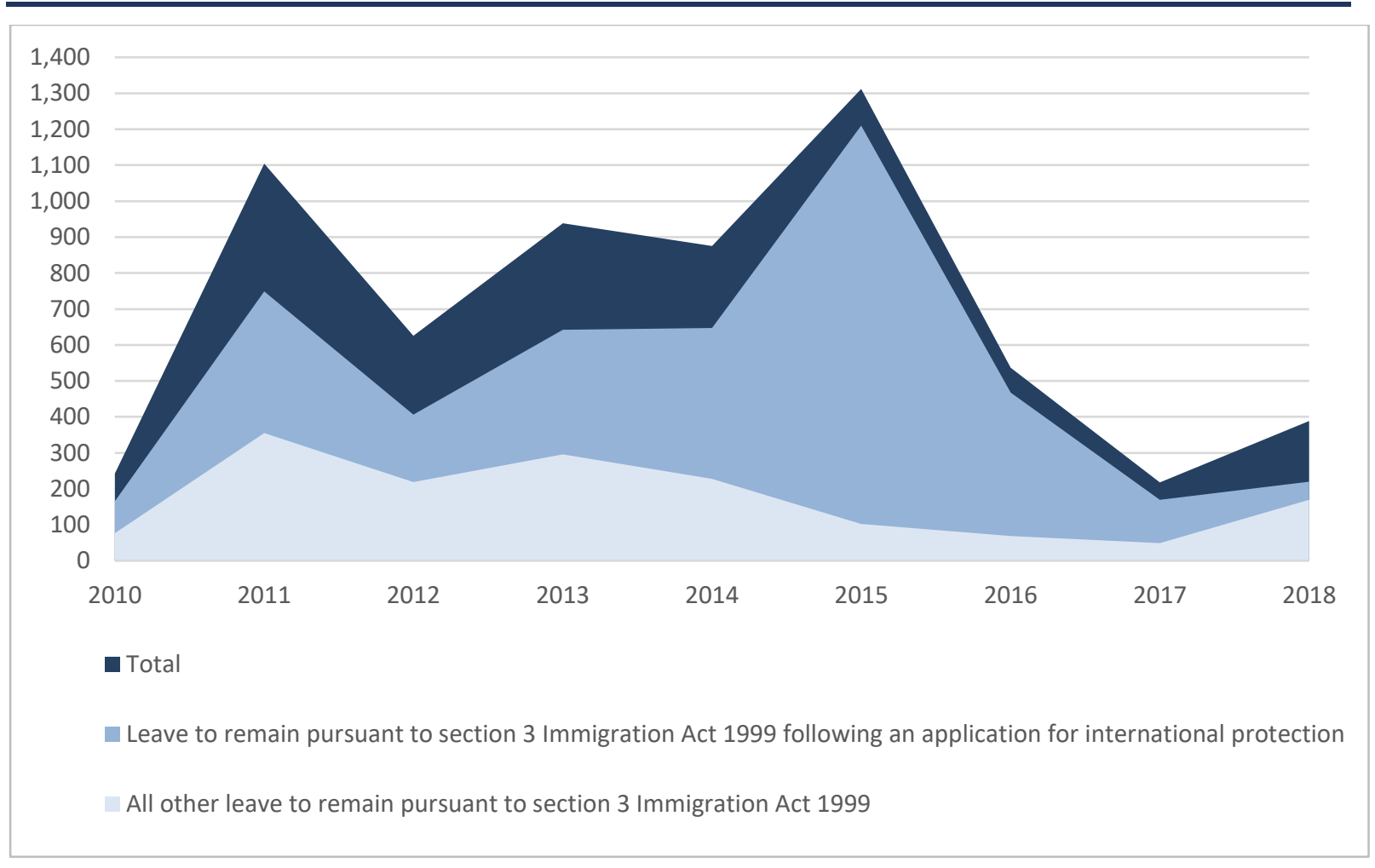

Source: Correspondence with RAU, Department of Justice and Equality, May 2019.

Data obtained from RAU for this study show that 165 persons were granted leave to remain in $\mathbf{2 0 1 0}$ following a decision not to make a deportation order under section 3 of the 1999 Act, having previously submitted an application for international protection. ${ }^{54}$ In 2011, the number of such persons granted leave to remain jumped to 749. While grants decreased in 2012 to 406, the number of persons granted leave to remain grew again to 642 in 2013. In 2015, leave to remain grants almost doubled to 1,210. The sharp increase reflects in part the Government's response to the 'McMahon Report', which recommended that persons who had been waiting for a protection or leave to remain decision for five 
years or more be granted protection status or leave to remain (Working Group to Report to Government on Improvements to the Protection Process, including Direct Provision and Supports to Asylum Seekers, 2015). In a progress audit, the Department of Justice Equality reported that cases longest in the system had been expedited (Department of Justice and Equality, 2017).

The number of persons granted leave to remain following a protection application subsequently decreased to 169 in 2017, while 220 persons were granted leave to remain in 2018. The decrease in persons granted leave to remain was partly attributed by the Government to the introduction of the 2015 Act and the transfer of cases to IPO, which the Government stated had impacted on the number of cases brought to a conclusion in 2017. The Irish Times also reported that efforts in 2015 and 2016 to process international protection applications of persons that had been waiting for a decision for five years may have also contributed to the drop in number of persons granted leave to remain in 2017 (Power, 2018)..$^{55}$

\section{Persons granted permission to remain under the Syrian Humanitarian} Admission Programme (SHAP)

From 14 March to 30 April 2014, Ireland operated this one-off administrative family sponsorship scheme. Out of all SHAP applications made on behalf of 308 persons, Table 1.2 shows that 114 persons were granted permission to remain in Ireland in 2014 and a further five were granted permission in 2015 (Arnold and Quinn, 2016) (see Section 2.6 of this report). 


\section{Granting national statuses for protection reasons}

This chapter examines in more detail the various statuses in place that may be granted to persons who have a protection need. Information is provided on the background to each national status, including its basis in law and policy governing international protection and immigration. A distinction can be made between statuses that have been established expressly for the purpose of responding to the protection needs of non-EU nationals and those statuses that lie within broader immigration legislation governing the residence of non-Irish nationals.

The chapter also sets out in which scenarios a person with a protection need may be granted each status and the procedures in place for granting the status.

\subsection{PROGRAMME REFUGEE STATUS}

Persons resettled to Ireland are granted programme refugee status. Programme refugee status is provided for by section 59 of the 2015 Act. Section 59(1) defines a programme refugee as:

a person to whom permission to enter and remain in the State for resettlement, or for temporary protection other than temporary protection provided for in section 60 [of the 2015 Act], has been given by the Government or the Minister and whose name is entered in a register established and maintained by the Minister, whether or not such person is a refugee within the meaning of the definition of "refugee" in section 2 [of the 2015 Act].

Between 2000 and 2016, programme refugee status was available pursuant to section 24(1) of the Refugee Act 1996 (the 1996 Act). Prior to the entry into force of the 1996 Act in 2000, programme refugee status had not been addressed in legislation. However, since the 1950s Ireland has resettled groups of persons fleeing war or conflict as programme refugees, on foot of government decisions, in response to requests from the United Nations High Commissioner for Refugees (UNHCR) (O'Regan, 1997; Arnold and Quinn, 2016). ${ }^{56}$ Programme refugee status was included in the 1996 Act in order to clarify the legal status of persons resettled in the State as programme refugees. ${ }^{57}$ Section 24(7) of the 1996 Act, as amended, provided that the Minister for Justice and Equality (the Minister) may enter into agreements with UNHCR for the reception and resettlement of refugees. Section 59(3) of the 2015 Act, which repealed and replaced the 1996 Act, includes a similar provision, which states that the Minister may, after consultation with the Minister 
for Foreign Affairs and Trade, enter into agreements with UNHCR for the reception and resettlement in the State of programme refugees.

\subsubsection{Irish Refugee Resettlement Programme (IRRP)}

Following a government decision and approaches by UNHCR, Ireland agreed to participate in the UNHCR Refugee Resettlement Programme, in which participating states accept a quota of refugees for resettlement each year and, in 1998, formally established a refugee resettlement programme (Stanley et al., 2010; Arnold and Quinn, 2016). The first arrivals under the programme, commonly referred to as the Irish Refugee Resettlement Programme (IRRP), which is run by the Government in collaboration with UNHCR, were approved for admittance in 1999 and arrived in 2000.58

UNHCR, in co-operation with partner organisations at a local level, identify the most vulnerable persons for resettlement purposes, regardless of their race, religion, nationality or ethnicity. ${ }^{59}$ For a person to be eligible for resettlement as a programme refugee, they must be determined to be a refugee by UNHCR in the country of refuge. In addition, resettlement must be identified by UNHCR to be the most appropriate durable solution for the person or family (UNHCR, 2011). ${ }^{60}$ Persons or families are identified as having a resettlement need if they are at risk in the country of refuge or have particular needs that correspond with the various UNHCR resettlement categories, including:

- legal and/or physical protection needs,

- survivors of torture and/or violence,

- medical needs,

- women and girls at risk,

- family reunification,

- children and adolescents at risk, and

- lack of foreseeable alternative durable solution (UNHCR, 2011).

Where a person or family is determined by UNHCR to be eligible for resettlement, UNHCR then refers the cases to Ireland for consideration. Referrals for resettlement are submitted by UNHCR to the Irish Refugee Protection Programme (IRPP) unit of the Department of Justice and Equality. Ireland considers whether or not those referred are acceptable for interview and then arranges what is referred to as a selection mission. Selection missions are carried out by Irish refugee resettlement teams, comprised of officials of the IRPP unit and An Garda Síochána. The Health Service Executive (HSE) is consulted in advance on the quota of medical 
cases and the types of conditions that can or cannot be treated effectively in Ireland. Security screenings are also undertaken by the selection team who individually assess each case to ensure the refugee does not pose a threat to national security or public order. On return to Ireland, a submission is prepared for the Minister to approve. Decisions are normally made within three months of the mission, but may take longer. Decisions relating to urgent medical cases take approximately four weeks (Arnold and Quinn, 2016).

Quotas for the intake of programme refugees are set and reviewed annually by the Minister (Arnold and Quinn, 2016). The Minister makes decisions regarding the country of origin/country of first asylum, in consultation with the Department of Foreign Affairs and Trade and UNHCR (Government of Ireland, 2018). Family groups are prioritised for resettlement (Arnold and Quinn, 2016).

On 20 July 2015, the Council of the European Union agreed to establish an EU-wide resettlement scheme to offer 20,000 places to refugees across EU Member States (Council of the European Union, 2015). The European Commission had initially proposed that Ireland would receive 272 people by the end of 2016 (European Commission, 2015b). However, the then Minister, Frances Fitzgerald TD, announced that government approval would be sought to resettle 300 people as part of the EU scheme. ${ }^{61}$ Prior to the EU resettlement proposals, the Government had pledged 100 resettlement places for 2015 and a further 120 places for 2016 (Joyce and Whelan, 2015). Following a government decision on 9 June 2015, the final number of resettlement places to which Ireland thus committed under the EU scheme amounted to 520 (Council of the European Union, 2015).

\subsubsection{Irish Refugee Protection Programme (IRPP)}

In September 2015, the Government established the IRPP in which it committed to accepting up to 4,000 persons through relocation and resettlement under the IRRP. The IRPP is the umbrella under which resettlement has operated in Ireland since 2015 (Arnold and Quinn, 2016). In contrast to resettled persons, those relocated to Ireland under the relocation strand of the IRPP or following search and rescue missions do not receive programme refugee status; instead, they submit an application for international protection following their arrival in Ireland, on the basis of which they may be granted refugee status, subsidiary protection or permission to remain under section 49 of the 2015 Act (see Section 2.2 of this report). 
Under the resettlement strand, the Government reiterated its commitment to resettling 520 persons in Ireland from Lebanon. ${ }^{62}$ On 6 July 2016, the Government decided to add an additional 260 resettlement places to its IRPP commitments for $2017 .{ }^{63}$ On 19 November 2016, it pledged a further 260 resettlement places for refugees in Lebanon, ${ }^{64}$ bringing the total number of places allocated to the resettlement strand of the IRPP to 1,040. One year later, on 15 September 2017, it announced its intention to resettle 600 refugees in 2018 as part of a European Commission resettlement pledging exercise, which aimed to provide 50,000 resettlement places across the EU. ${ }^{65}$ The pledge of 600 resettlement places for 2018 included 255 people out of the outstanding commitments made for 2017 and an additional 345 persons. ${ }^{66}$ On 14 November 2017, the Government announced it had committed to admitting a further 600 refugees through resettlement in $2019,{ }^{67}$ following a European Commission recommendation that the EU should offer at least 50,000 resettlement places to persons in need of international protection by 31 October 2019 (European Commission, 2017). The overall commitment under the resettlement strand of the IRPP was thus revised to $1,985.68$

A mission of the IRPP unit to Lebanon in March 2019 selected 331 refugees for resettlement to Ireland. A further mission to Jordan was due to take place in July 2019 to select approximately 300 refugees. The Government stated that the remaining programme refugees are due to be resettled in Ireland by the end of $2019 .{ }^{69}$

Department of Justice and Equality, 'Ireland to accept up to 4,000 persons under relocation and resettlement programmes- Fitzgerald', press release, 10 September 2015, http://www.justice.ie/en/JELR/Pages/PR15000463. Department of Justice and Equality, 'Tánaiste confirms plans to accept 260 more refugees under resettlement programme', press release, 6 July 2016,

http://www.inis.gov.ie/en/INIS/Pages/T\%C3\%A1naiste\%20confirms\%20plans\%20to\%20accept\%20260\%20more\%2 Orefugees\%20under\%20resettlement\%20programme. Department of Justice and Equality, 'Tánaiste confirms plans to welcome a further 260 refugees from Lebanon under resettlement programme', press release, 29 November 2016, http://www.inis.gov.ie/en/INIS/Pages/press-releasetanaiste-confirms-acceptance-of-further-refugees-from-Lebanon. Department of Justice and Equality, 'Minister Flanagan announces Ireland will resettle 600 refugees in 2018 ', press release, 15 September 2017, http://www.justice.ie/en/JELR/Pages/PR17000295. Ibid; Parliamentary Question [51753/17], 5 December 2017, available at http://www.justice.ie/en/JELR/Pages/PQ05-12-2017-110. reunification scheme in support of refugees and their families under the Irish Refugee Protection Programme', press release, 14 November 2017, http://www.justice.ie/en/JELR/Pages/PR17000383. 


\subsubsection{Irish Refugee Protection Programme Humanitarian Admission Programme (IHAP)}

In November 2017, the Minister announced the introduction of the Irish Refugee Protection Programme Humanitarian Admission Programme (IHAP) in order to deliver on the Government's commitment to admit 4,000 persons to Ireland under the IRPP..$^{70}$ IHAP was established to provide humanitarian admission to 530 eligible family members of Irish citizens and those with international protection and programme refugee status. IHAP consisted of two rounds of calls for persons to propose eligible family members for consideration; the first call ran from 14 May to 30 June 2018, while a second call ran from 20 December 2018 to 8 February 2019. Eligible family members included an adult child, a grandparent, a related minor child without parents for whom the proposer has parental responsibility, a vulnerable close family member who does not have a spouse/partner or other close relative to support them, in addition to a minor child, parent, or spouse/civil partner, where these members were not eligible for reunification with a sponsor under the 2015 Act. $^{71}$ Eligible family members were also required to be nationals of what UNHCR listed as the top ten major source countries of refugees: Syria, Afghanistan, South Sudan, Somalia, Sudan, Democratic Republic of the Congo, Central African Republic, Myanmar, Eritrea and Burundi. Priority is given by the Department of Justice and Equality to proposers that can accommodate/provide housing and supports to family members. ${ }^{72}$ IHAP operates on the basis of discretionary ministerial power and its beneficiaries receive programme refugee status. $^{73}$

Introducing the programme, the Minister of State for Justice at the Department of Justice and Equality with special responsibility for equality, immigration, and integration stated that persons admitted under IHAP 'will be part of IRPP and will therefore receive a status in their own right rather than a dependency status on their family member. ${ }^{74}$ It was further stated by the Minister for Justice and Equality that granting beneficiaries of IHAP a status in their own right 'is important for their long term integration and sense of belonging in our communities' ${ }^{75}$ In a admissions programme', press release, 12 May 2018, available at http://www.justice.ie/en/JELR/Pages/PR18000149. Department of Justice and Equality, 'Irish Refugee Protection Programme Humanitarian Admission Programme 2 (IHAP)', http://www.inis.gov.ie/en/INIS/Pages/irish-refugee-protection-programme-humanitarian-admissionprogramme-2-(ihap).

Department of Justice and Equality, 'Irish Refugee Protection Programme Humanitarian Admission Programme 2 (IHAP)', available at http://www.inis.gov.ie/en/INIS/Pages/irish-refugee-protection-programme-humanitarianadmission-programme-2-(ihap); Department of Justice and Equality, 'Irish Refugee Protection Programme (IRPP) Humanitarian Admission Programme 2 (IHAP) Proposal Form', available at https://www.irishrefugeecouncil.ie/wpcontent/uploads/2018/05/ihap-application-form.pdf. lbid.

74 Department of Justice and Equality, 'Ministers Flanagan and Stanton announce opening of the new humanitarian admissions programme', press release, 12 May 2018, http://www.justice.ie/en/JELR/Pages/PR18000149. 
submission to the Joint Oireachtas Committee on Justice and Equality, the Minister stated that the introduction of IHAP was evidence of the Minister's willingness to proactively respond to humanitarian crises (Houses of the Oireachtas, 2019). The Joint Oireachtas Committee on Justice and Equality in its Report on scrutiny of the International Protection (Family Reunification) (Amendment) Bill 2017 [PMB] noted that, while stakeholders welcomed IHAP, it was of the view that it is 'too limited in terms of eligibility, and the temporary nature of the programme creates further uncertainty for those seeking reunification' (Houses of the Oireachtas, 2019).

In the first call for proposals, a total of 101 proposals were granted in respect of 171 beneficiaries, 110 of whom have arrived in the State as of November $2019 .{ }^{76}$

\subsubsection{Community Sponsorship Ireland (CSI)}

In March 2019, the Government launched the pilot Community Sponsorship Ireland (CSI) initiative. CSI invites private citizens and community-based organisations to welcome and integrate refugee families into their community. Persons eligible must be residing outside of Ireland and must have been identified by UNHCR and accepted by the Government as individuals in need of protection (Department of Justice and Equality, 2019a). Persons arriving through the initiative do so through the existing procedures in place under the IRRP. Beneficiaries are granted programme refugee status. The pilot phase was to last until October 2019 during which 50 refugees were expected to be resettled to Ireland. ${ }^{77}$ On 15 November 2019, the Government officially launched the CSI scheme as a national programme. ${ }^{78}$ As of November 2019, five Syrian families (17 refugees in total) have been resettled in Ireland under $\mathrm{CSI}^{79}$

\subsubsection{Unaccompanied children}

While unaccompanied children are deemed eligible for resettlement by UNHCR, they are not included in the IRRP (Arnold and Quinn, 2016). However, in November 2016, the Government established the Calais Special Project, in which it committed to admitting up to 200 unaccompanied minors who had resided in the former migrant camp in Calais. Of a total 41 unaccompanied minors admitted to Ireland under the Project, 39 were granted programme refugee status on arrival (Groarke

Consultation with the Department of Justice and Equality, November 2019.

Department of Justice and Equality, 'Minister Stanton calls on communities to sponsor a refugee family as he launches pilot Community Sponsorship initiative', press release, 6 March 2019,

http://www.justice.ie/en/JELR/Pages/PR19000059; Office for the Promotion of Migrant Integration, 'Minister of State David Stanton T.D., launches Community Sponsorship Ireland',

http://www.integration.ie/en/ISEC/Pages/WP19000003. Department of Justice and Equality, 'Minister Stanton Officially Launches Refugee Community Sponsorship Ireland', press release, 15 November 2019, http://www.justice.ie/en/JELR/Pages/PR19000282. Ibid. 
and Arnold, 2018). ${ }^{80}$ The Government decided to grant such unaccompanied minors programme refugee status to 'allow them to begin their new lives with certainty of their legal status in the country from day one' ${ }^{81}$

\subsubsection{Relocated programme refugees}

Ireland relocated ten people, consisting of three families, from Malta each year between 2011 and 2013, 'as a gesture of support to the Maltese government at a time of exceptional migratory pressure' (Department of Justice and Equality, 2013). ${ }^{82}$ Relocation during this period, prior to the establishment of the IRPP, involved the relocation of persons already recognised as refugees from one EU Member State to another for resettlement purposes (Arnold and Quinn, 2016). Such persons were granted programme refugee status on arrival. Persons relocated under the relocation strand of the IRPP are not granted programme refugee status and instead submit an application for international protection following arrival in Ireland, on the basis of which they may be granted refugee status, subsidiary protection or permission to remain under section 49 of the 2015 Act (see Section 2.2 of this report).

\subsubsection{Profile of persons granted programme refugee status}

Table 2.1 presents the country of origin of persons granted programme refugee status between 2010 and 2018 . 
TABLE 2.1 COUNTRY OF ORIGIN OF PERSONS GRANTED PROGRAMME REFUGEE STATUS, 2010-2018

\begin{tabular}{|c|c|c|c|c|c|c|c|}
\hline & $\begin{array}{c}\text { Nationality } \\
1\end{array}$ & Nationality 2 & $\begin{array}{c}\text { Nationality } \\
3\end{array}$ & $\begin{array}{c}\text { Nationality } \\
4\end{array}$ & $\begin{array}{c}\text { Nationality } \\
5\end{array}$ & Other & $\begin{array}{c}\text { Grand } \\
\text { total }\end{array}$ \\
\hline \multirow{2}{*}{2010} & Iraq & Burma/Myanmar & Syria & & & & \\
\hline & 16 & $<5$ & $<5$ & - & - & - & 20 \\
\hline \multirow[t]{2}{*}{2011} & Sudan & Eritrea & Ethiopia & Iraq & Morocco & & \\
\hline & 23 & 9 & 6 & 6 & $<5$ & - & 45 \\
\hline \multirow[t]{2}{*}{2012} & DRC & Somalia & Iran & Egypt & Liberia & & \\
\hline & 20 & 10 & 5 & 5 & 4 & 5 & 49 \\
\hline \multirow[t]{2}{*}{2013} & Afghanistan & DRC & Somalia & Sudan & Palestine & & \\
\hline & 31 & 31 & 15 & 5 & $<5$ & - & 86 \\
\hline \multirow[t]{2}{*}{2014} & Syria & DRC & & & & & \\
\hline & 89 & 7 & - & - & - & - & 96 \\
\hline \multirow[t]{2}{*}{2015} & Afghanistan & DRC & Somalia & Sudan & Palestine & & \\
\hline & 31 & 31 & 15 & 5 & $<5$ & - & 86 \\
\hline \multirow[t]{2}{*}{2016} & Syria & DRC & & & & & \\
\hline & 89 & 7 & - & - & - & - & 96 \\
\hline \multirow[t]{2}{*}{2017} & Syria & Iraq & & & & & \\
\hline & 149 & 27 & - & - & - & - & 176 \\
\hline \multirow[t]{2}{*}{2018} & Syria & Iraq & Eritrea & & & & \\
\hline & 333 & 5 & 11 & & & & 349 \\
\hline
\end{tabular}

Source: $\quad$ Correspondence with the IRPP unit, Department of Justice and Equality, May 2019.

Notes: $\quad$ Figures under five are represented by $<5$. DRC $=$ Democratic Republic of the Congo.

Figure 2.1 provides an age breakdown of persons granted programme refugee status between 2010 and 2018. The higher number of persons under the age of 18 reflects in part the priority given by the Government to family groups in its resettlement commitments. Those under 18 years who were granted programme refugee status in 2017 and 2018 include 39 unaccompanied children that were granted programme refugee status on arrival in Ireland under the Calais Special Project (Groarke and Arnold, 2018). 


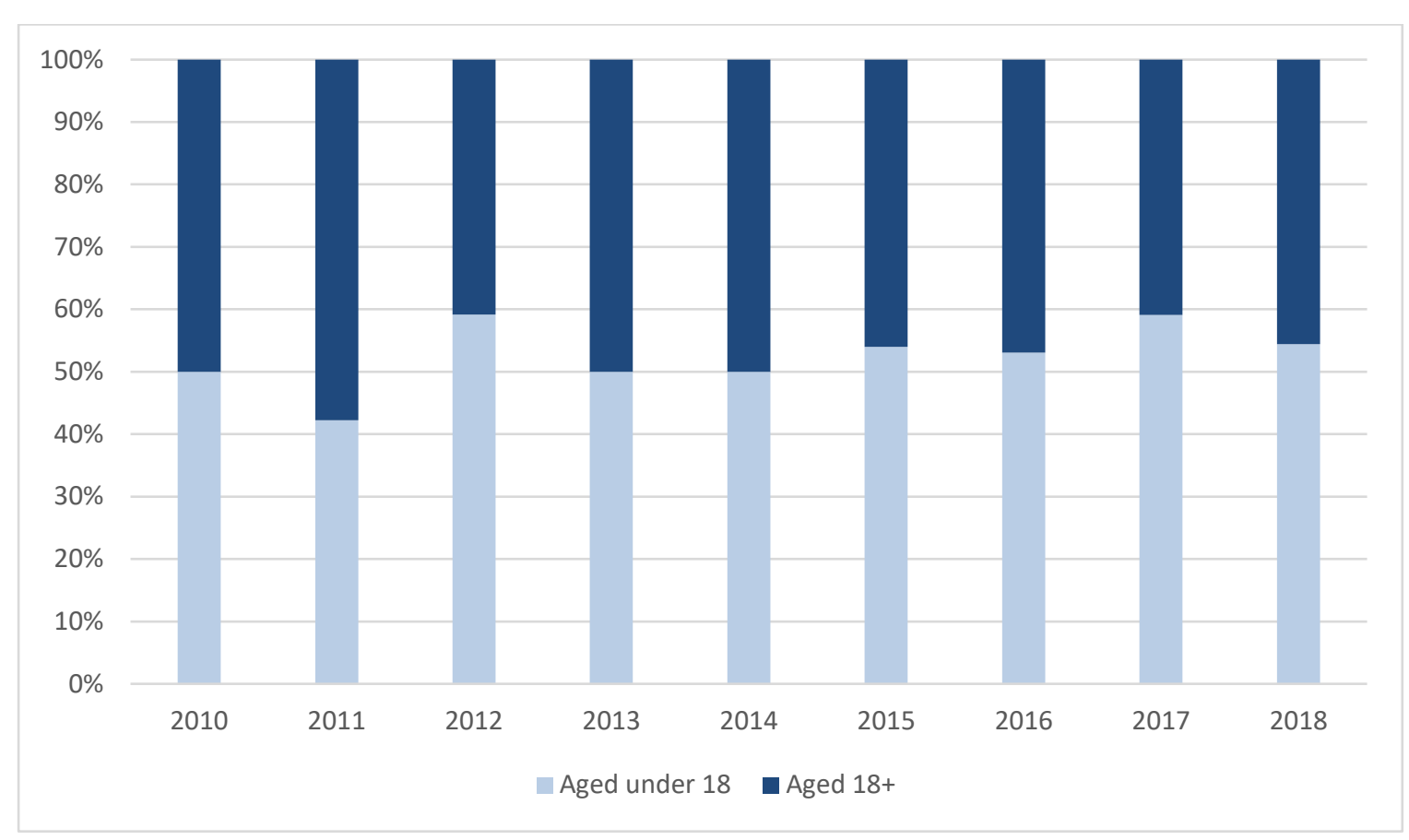

Source: Correspondence with the IRPP unit, Department of Justice and Equality, May 2019.

Figure 2.2 provides a gender breakdown of grants of programme refugee status from 2010 to 2018.

FIGURE 2.2 PERSONS GRANTED PROGRAMME REFUGEE STATUS BY GENDER, 2010-2018

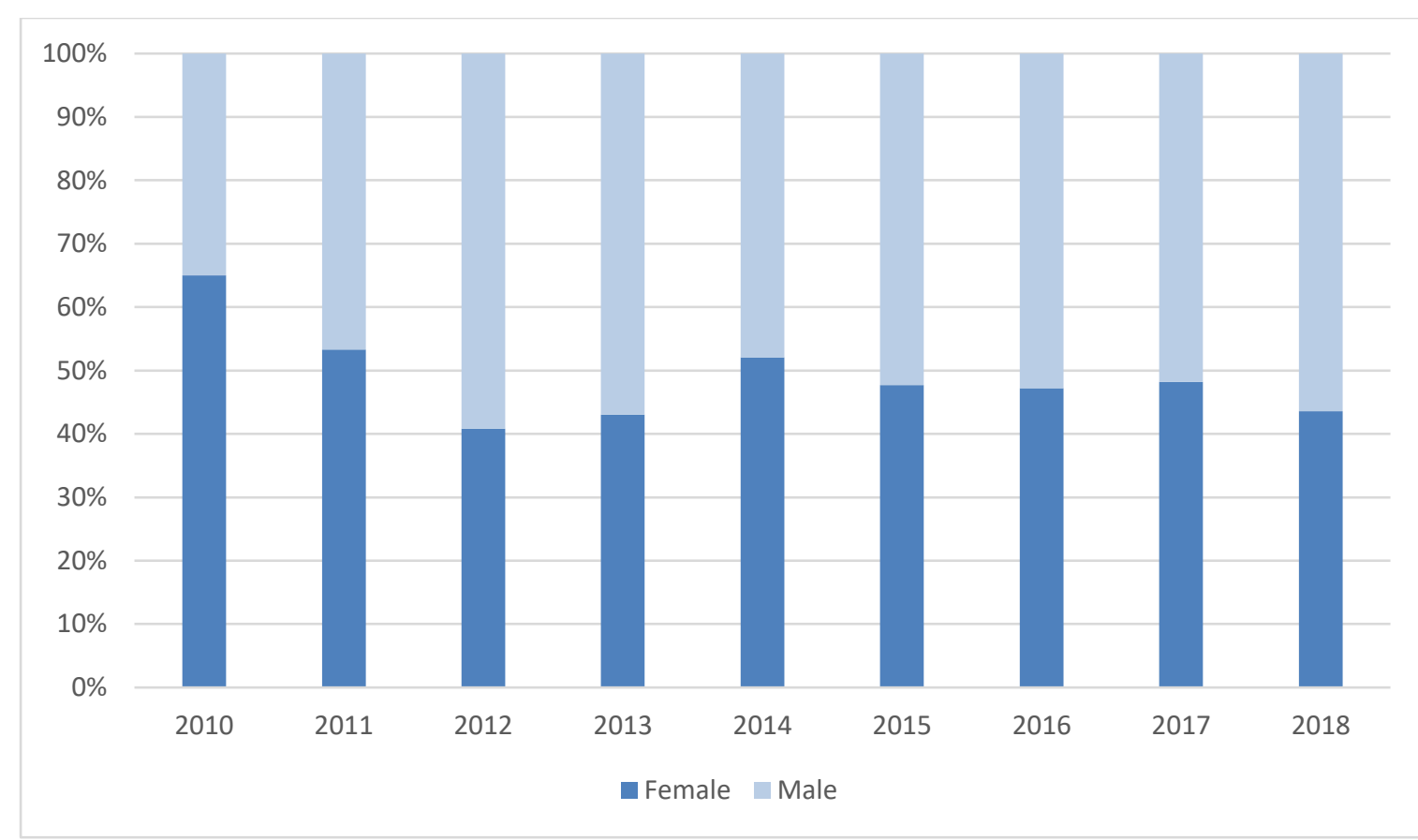

Source: Correspondence with the IRPP unit, Department of Justice and Equality, May 2019.

Table 2.2 shows separate available data on the country of origin of 141 of the beneficiaries granted following the first call for proposals under IHAP. The majority of beneficiaries are of Syrian origin, followed by the following countries of origin: the Democratic Republic of the Congo, Afghanistan, Sudan and Somalia. 
TABLE 2.2 COUNTRY OF ORIGIN OF 141 BENEFICIARIES APPROVED UNDER IHAP

\begin{tabular}{|c|c|c|c|c|c|c|}
\hline Nationality 1 & Nationality 2 & Nationality 3 & Nationality 4 & Nationality 5 & Other & Total \\
\hline Syria & DRC & Afghanistan & Sudan & Somalia & & \\
\hline 56 & 31 & 22 & 15 & 12 & 5 & 141 \\
\hline $\begin{array}{ll}\text { Source: } & \text { Parliame } \\
& 2019-448\end{array}$ & ry Question [11S & 19], 15 January 2 & 19, available at ht & p://www.justice.ie/ & LR/Page & \\
\hline
\end{tabular}

Available data on 166 IHAP beneficiaries reported by the Department of Justice and Equality show that 60 per cent are female, 14 per cent are under the age of 18 and 33 per cent are aged 55 and over (Department of Public Expenditure and Reform, 2019).

\subsection{PERMISSION TO REMAIN UNDER SECTION 49 OF THE INTERNATIONAL PROTECTION ACT 2015}

The 2015 Act introduced a permission to remain status for international protection applicants who receive a negative decision on refugee status and subsidiary protection. Section 49 of the 2015 Act provides for the granting of permission to remain in the State to an individual following a refusal to grant them international protection. Section 49(1) states that, where a recommendation is made that an applicant for international protection should be given neither a refugee declaration nor a subsidiary protection declaration, the Minister shall consider whether to give the applicant permission to remain.

Permission given under section 49 of the 2015 Act is deemed to be permission given under section 4 of the Immigration Act 2004; the provisions of the 2004 Act thus apply (see Section 2.5 of this report). ${ }^{83}$

2.2.1 Persons that may be granted permission to remain under section 49 of the 2015 Act

Persons who submit an application for international protection may be granted refugee status, subsidiary protection or permission to remain under section 49 of the 2015 Act. In addition to spontaneous applicants for international protection, persons arriving through the relocation strand of the IRPP and those relocated to Ireland following search and rescue missions submit an application for international protection on arrival in Ireland.

\section{Persons relocated to Ireland under the relocation strand of the IRPP}

Under the relocation strand of the IRPP, Ireland committed to relocating 2,622 persons from Italy and Greece in line with commitments made under the EU relocation programme established by two EU Council decisions in 2015. In total, 1,022 people, including six unaccompanied minors, were welcomed to Ireland from 
Greece by March 2018, when the Minister announced the conclusion of relocation from Greece. ${ }^{84}$ No asylum seekers have been relocated from Italy to date. ${ }^{85}$ Persons relocated to Ireland have their application for international protection examined in Ireland and may be granted refugee status, subsidiary protection or permission to remain under section 49 of the 2015 Act. In 2017, four individuals relocated to Ireland under the IRPP were granted permission to remain under section 49 of the 2015 Act following assessment of their application for international protection by IPO. ${ }^{86}$

\section{Persons arriving in Ireland following search and rescue missions in the Mediterranean}

In addition to its relocation and resettlement commitments, Ireland has accepted a number of people rescued by non-governmental organisations' (NGO) ships in the Mediterranean. The Government has reported it accepted 58 persons from search and rescue missions in $2018 .^{87}$ In June 2018, it announced that it would relocate 25 persons to Ireland from the NGO ship 'Lifeline', which docked in Malta after rescuing 234 people in the Mediterranean off the Libyan coast. ${ }^{88} \mathrm{~A}$ total of 26 persons (22 adults and four unaccompanied children) were admitted as relocated persons under the search and rescue strand of the IRPP. ${ }^{89}$ Ireland also committed to taking in up to 25 persons rescued by 'Diciotti', an Italian coastguard ship, in August $2018 .^{90} \mathrm{~A}$ total of 16 rescued people arrived in Ireland in December 2018 (Sheridan, 2019). A further 16 people arrived in Ireland in November 2018, following their rescue by the NGO ship 'Aquarius' and disembarkation in Sicily (Sheridan, 2019).

In January 2019, the Government announced it would relocate five unaccompanied minors rescued and disembarked in Malta. ${ }^{91}$ The Government also announced it would relocate a number of people rescued by 'Ocean Viking' in August 2019.92

To date, persons admitted to Ireland following search and rescue missions are admitted under the search and rescue strand of the IRPP. Following arrival in Parliamentary Question [33770/19], 23 July 2019, available at http://www.justice.ie/en/JELR/Pages/PQ-23-072019-922. RTÉ, 'Lifeline migrant rescue boat docks in Maltese port', 27 June 2018, https://www.rte.ie/news/world/2018/0627/973606-lifeline-boat/. Parliamentary Question [8163/19], 19 February 2019, available at http://www.justice.ie/en/JELR/Pages/PQ-19-022019-289. Irish Times, 'Ireland to take up to 25 migrants who were stuck on boat off Italy', 26 August 2018, https://www.irishtimes.com/news/social-affairs/ireland-to-take-up-to-25-migrants-who-were-stuck-on-boat-offitaly-1.3608342. to Ireland in solidarity with Malta', 9 January 2019, http://www.inis.gov.ie/en/INIS/Pages/press-release-ministerflanagan-and-minister-stanton-agree-to-invite-unaccompanied-minors-to-ireland-in-solidarity-with-malta. 
Ireland, they submit an application for international protection, which may result in a grant of either refugee status, subsidiary protection or permission to remain under the 2015 Act.

\subsubsection{Determination procedure}

The International Protection Act 2015 (the 2015 Act) forms the basis of the legal framework governing international protection in Ireland. The 2015 Act, which came into force on 31 December 2016, introduced a new single application procedure whereby applications for international protection (refugee status and subsidiary protection) and permission to remain are assessed as part of a single procedure.

Prior to the 2015 Act, Ireland operated a sequential asylum process in which applications for refugee status were assessed under the Refugee Act 1996 and applications for subsidiary protection under the European Union (Subsidiary Protection) Regulations 2013 (S.I. No. 426 of 2013), as amended. At that time, the granting of permission to remain following an unsuccessful application for refugee status or subsidiary protection did not have a statutory basis in international protection legislation. Instead, those seeking protection who did not satisfy the criteria for a declaration of refugee or subsidiary protection status would typically make representations to the Minister for Justice and Equality regarding why they ought not to be deported from the State, pursuant to section 3 of the Immigration Act 1999, as amended, and should be granted 'leave to remain'. The 2015 Act provides that unsuccessful applicants for international protection are subject to a permission to remain procedure under that Act; one that does not require an unsuccessful international protection applicant to be issued with a proposal to deport before permission to remain is considered (see Section 2.4 of this report). Stanley (2017) states that section 49 provides 'a positive means for granting permission and weighing rights, rather than a mechanism to determine if deportation would be justified and proportionate'.

The Minister has a broad discretion to grant permission to remain pursuant to section 49 of the 2015 Act. In deciding whether or not to give an unsuccessful international protection applicant permission to remain, the Minister is required to have regard to the applicant's family and personal circumstances and their right to respect for his or her private and family life, having due regard to:

(a) the nature of the applicant's connection with the State, if any,

(b) humanitarian considerations,

(c) the character and conduct of the applicant both within and (where relevant and ascertainable) outside the State (including any criminal convictions),

(d) considerations of national security and public order, and

(e) any other considerations of the common good. ${ }^{93}$ 
The Minister is required to have regard to any information presented in the applicant's application for international protection, including any statement made by the applicant at the preliminary interview and personal interview, and any information submitted by the applicant. ${ }^{94}$ The applicant may submit information relevant to the Minister's decision on whether to grant permission to remain at any stage before the conclusion of an examination of the application for international protection. Where an applicant becomes aware of a change of circumstances that would be relevant to the Minister's decision to grant permission to remain before the examination of the international protection application concludes, they must inform the Minister. ${ }^{95}$

Applications for international protection are processed by IPO, which if granted will be a recommendation to grant refugee status or subsidiary protection or a decision to grant permission to remain. The final decision in respect of grants of refugee status and subsidiary protection are a matter for the Ministerial Decisions Unit. If an application for international protection is refused, the determination of permission to remain under section 49 of the 2015 Act is carried out by an officer of the Minister in IPO.${ }^{96}$ The Minister must notify the person in writing and their legal representative of the decision and the reasons for it. ${ }^{97}$ The decisions on international protection and permission to remain are provided to the applicant at the same time.

There is no right to appeal a first-instance refusal of permission to remain under section 49 of the 2015 Act. If the Minister refuses the application for permission to remain, the applicant may then proceed to appeal against the refusal of international protection to the International Protection Appeals Tribunal (IPAT). ${ }^{98}$ If the refusal of international protection is upheld by IPAT, the applicant can submit any additional information that would have been relevant to the Minister's initial decision on permission to remain if that information had been in the possession of the Minister when making such decision, and any information as to a change of circumstances that would have been relevant to that decision. ${ }^{99}$ The applicant must submit such information five days from the date of receipt of the IPAT decision. ${ }^{100}$ The Minister will then review the initial decision to refuse permission to remain. ${ }^{101}$ The review of a first-instance refusal of permission to remain under

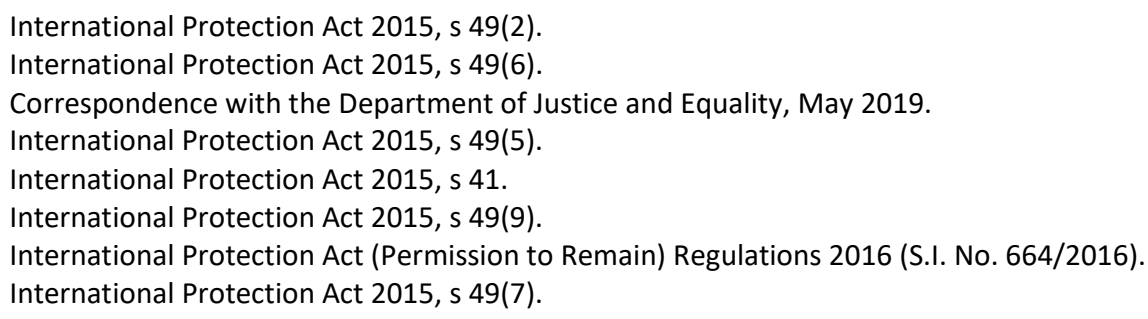


section 49 of the 2015 Act is carried out by an officer of the Minister in IPO. ${ }^{102}$ The Minister must notify the applicant and their legal representative in writing of the decision on review, accompanied by a statement of the reasons for the decision. ${ }^{103}$

At Bill stage, the Irish Refugee Council $(2011,2015)$ recommended that an individual right to appeal a refusal of permission to remain to IPAT be introduced in the Act in order to ensure effective access to a remedy against a refusal to grant permission to remain and to preclude the need for further legal proceedings by way of judicial review in the courts. The Immigrant Council of Ireland (2015) also recommended that the right of appeal should be extended to persons refused permission to remain in view of the fact that an application for permission to remain may give rise to fundamental human rights considerations.

2.2.3 Profile of persons granted permission to remain under section 49 of the 2015 Act

Table 2.3 presents the country of origin of persons granted permission to remain under section 49 of the 2015 Act in 2017 and 2018. 
TABLE 2.3 COUNTRY OF ORIGIN OF PERSONS GRANTED PERMISSION TO REMAIN UNDER SECTION 49 OF THE 2015 ACT, 2017-2018

\begin{tabular}{|l|l|l|l|l|l|l|l|} 
& $\begin{array}{c}\text { Nationality } \\
\mathbf{1}\end{array}$ & \multicolumn{1}{|c|}{$\begin{array}{c}\text { Nationality } \\
\mathbf{2}\end{array}$} & $\begin{array}{c}\text { Nationality } \\
\mathbf{3}\end{array}$ & $\begin{array}{c}\text { Nationality } \\
\mathbf{4}\end{array}$ & $\begin{array}{c}\text { Nationality } \\
\mathbf{5}\end{array}$ & \multicolumn{1}{|c|}{ Other } & Total \\
\hline $\mathbf{2 0 1 7}$ & Nigeria & South Africa & Mauritius & Zimbabwe & Mongolia & & \\
\hline & 20 & 12 & 6 & 6 & 5 & 23 & 72 \\
\hline
\end{tabular}

Source: $\quad$ Correspondence with RAU, Department of Justice and Equality, May 2019.

Note: Data for 2018 include permission to remain granted at first instance and granted following a review of a negative first instance decision on permission to remain.

Figure 2.3 shows that, since the 2015 Act came into force, the majority of persons granted permission to remain pursuant to section 49 are over 18 years.

FIGURE 2.3 PERSONS GRANTED PERMISSION TO REMAIN UNDER SECTION 49 OF THE 2015 ACT BY AGE, 2017-2018

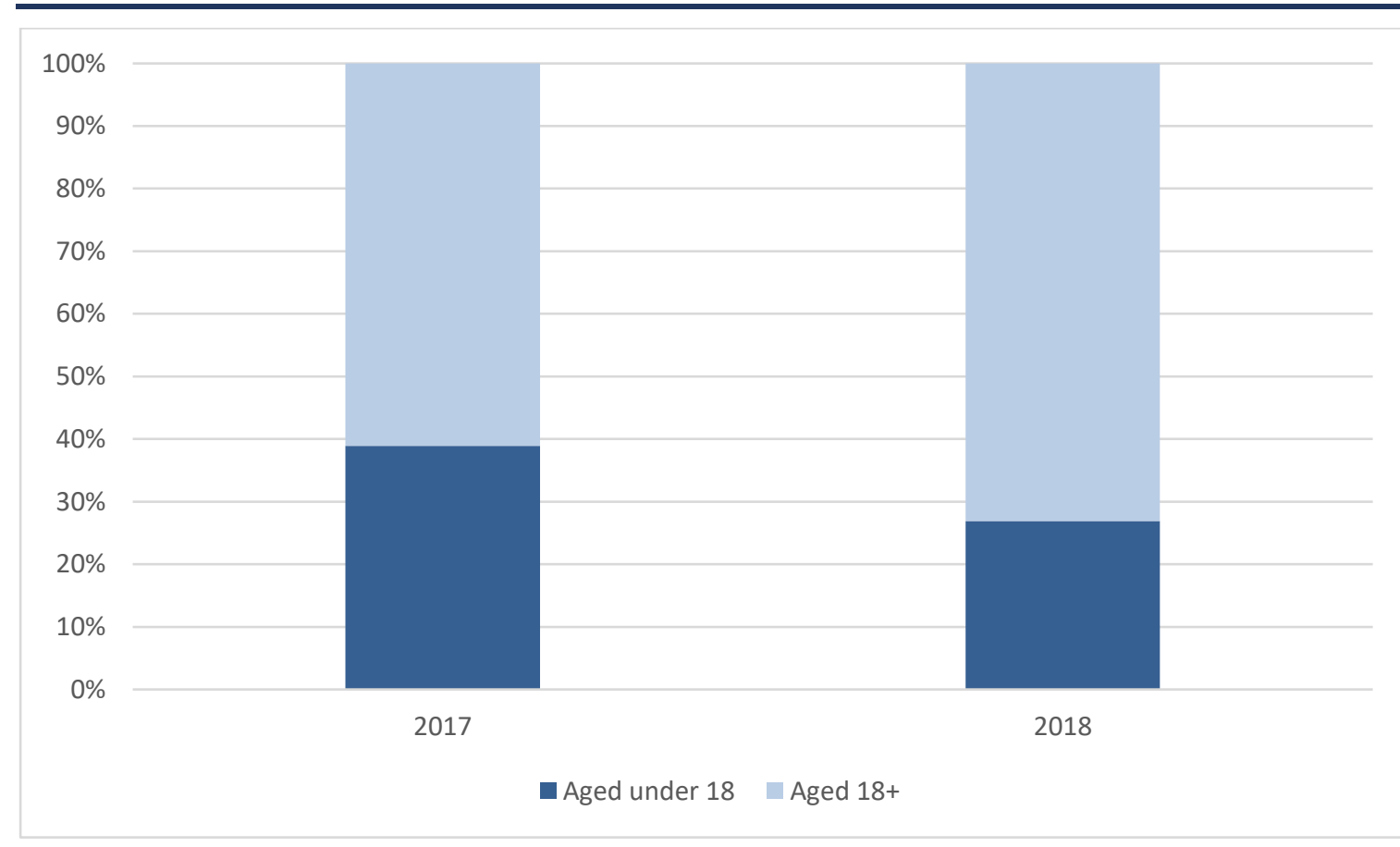

Source: $\quad$ Correspondence with RAU, Department of Justice and Equality, May 2019

Note: Data for 2018 include permission to remain granted at first instance and granted following a review of a negative first instance decision on permission to remain.

Figure 2.4 shows no large gender-based differences in relation to the granting of permission to remain. 
FIGURE 2.4 PERSONS GRANTED PERMISSION TO REMAIN UNDER SECTION 49 OF THE 2015 ACT BY GENDER, 2017-2018

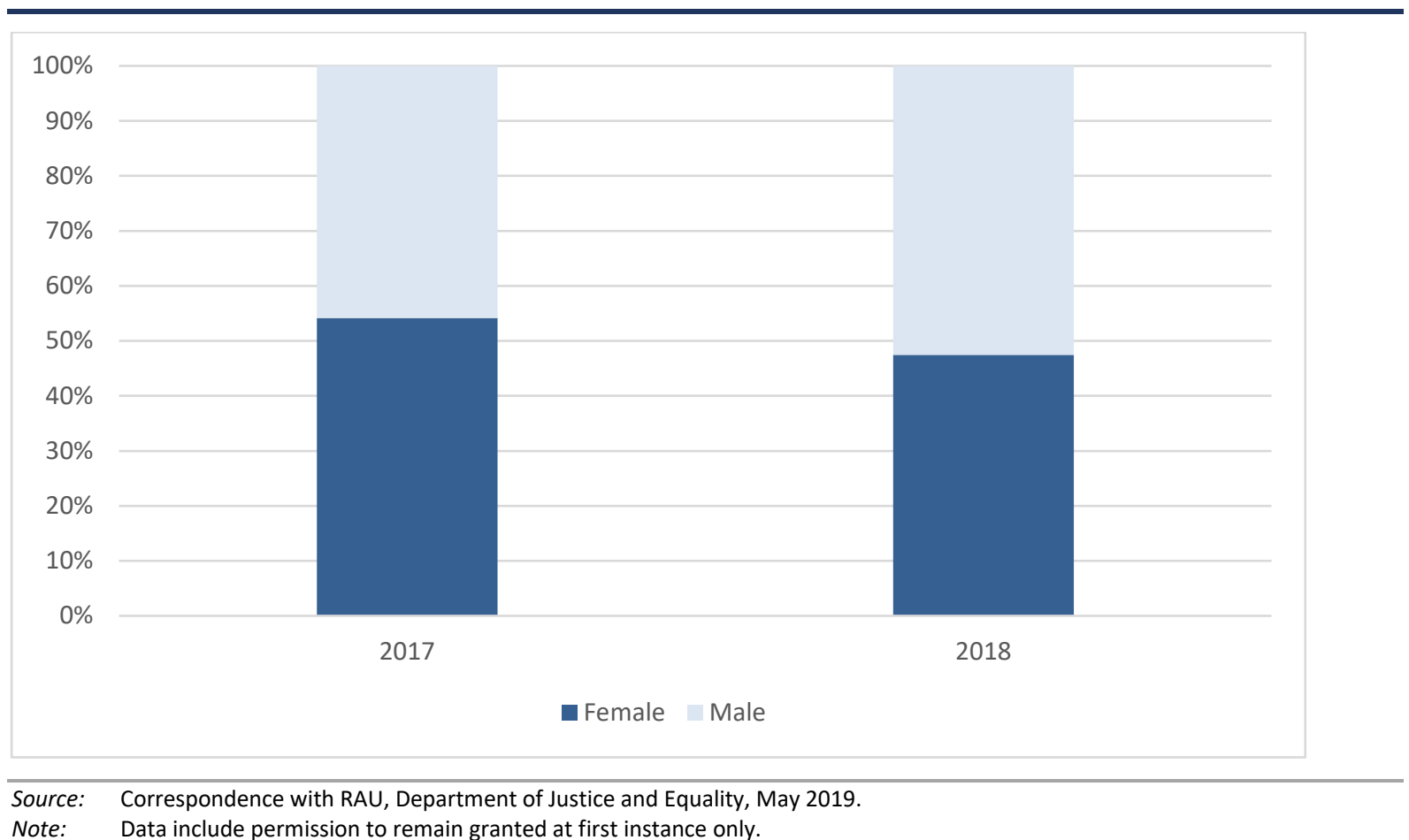

Note: Data include permission to remain granted at first instance only.

\subsection{PERMISSION TO REMAIN UNDER SECTION 50 OF THE 2015 ACT AS AN UNSUCCESSFUL APPLICANT FOR INTERNATIONAL PROTECTION WHO CANNOT BE REFOULED}

Section 50(1) of the 2015 Act sets out the prohibition of refoulement, which gives effect to the State's obligations under the 1951 Refugee Convention and international human rights law. ${ }^{104}$ It states that a person shall not be expelled or returned in any manner to the frontier of a territory where the life or freedom of the person would be threatened for reasons of race, religion, nationality or membership of a particular social group or political opinion, or where there is a serious risk that the person would be subjected to the death penalty, torture or other inhuman or degrading treatment or punishment. The High Court has held that the prohibition of refoulement in section 50(1) of the 2015 Act is wider than the protection against refoulement previously available to international protection applicants under section 5 of the Refugee Act 1996. ${ }^{105}$ states from returning individuals to a country where there is a real risk of them being subjected to persecution, torture, inhuman or degrading treatment or any other human rights violation (EMN, 2018). SG (Albania) v Minister for Justice and Equality [2018] IEHC 184. The High Court stated: Section 5(1) of the [1996] Act provides that "A person shall not be expelled from the State or returned in any manner whatsoever to the frontiers of territories where, in the opinion of the Minister, the life or freedom of that person would be threatened on account of his or her race, religion, nationality, membership of a particular social 
Section 50(4) of the 2015 Act states that a person to whom a grant of international protection and permission to remain under section 49 of the 2015 Act has been refused, and the deportation of whom would be contrary to the prohibition of refoulement, must be given permission to remain in the State. Permission given to a person under section 50 of the 2015 Act is deemed to be permission given under section 4 of the 2004 Act and the 2004 Act will apply to such persons (see Section 2.5 of this report). ${ }^{106}$ Section 50(4) of the 2015 Act provides on a statutory basis, for the first time in Irish law, a residency permission for persons who have received a negative decision on an application for international protection and permission to remain but who cannot be returned (Stanley, 2017). IPO stated that the prohibition of refoulement is currently considered in the context of a decision whether to grant permission to remain under section 49 of the 2015 Act and again by the Minister immediately prior to the signing of a deportation order. IPO stated that it does not grant permission to remain under any section other than section 49 of the 2015 Act. $^{107}$

\subsection{LEAVE TO REMAIN FOLLOWING A DECISION NOT TO MAKE A DEPORTATION ORDER UNDER SECTION 3 OF THE IMMIGRATION ACT 1999}

The Immigration Act 1999 (as amended) (the 1999 Act) governs the legal procedures for deportation from the State. Section 3 of the 1999 Act sets out the Minister's power to make a deportation order against a non-national. Such an order requires the individual in question to leave the State and to remain outside of the State. A non-national who is present in the State without permission may be issued with a proposal to deport, under section 3 of the Immigration Act 1999, in response to which they may make representations to the Minister against the making of a deportation order and to instead grant leave to remain.

While the 1999 Act was not established specifically for protection-related matters, its section 3 is a statutory mechanism that may provide an alternative means for granting leave to remain to an individual who is found to have protection-related needs. Leave to remain following a decision not to make a deportation order under section 3 of the Immigration Act 1999 may be granted at the discretion of the Minister for reasons relating to protection (such as against refoulement) or for other discretionary reasons not relating to protection (Stanley et al., 2010). As grants of leave to remain following a decision not to deport under section 3 of the 1999 Act do not set out the reasons for which they were granted, it is not possible

group or political opinion." However while s. 50(1)(a) of the 2015 Act is in similar terms, the section goes on to add ", or (b) there is a serious risk that the person would be subjected to the death penalty, torture or other inhuman or degrading treatment or punishment."

This decision is under appeal to the Supreme Court. 
to say to what extent this mechanism is granted to persons for protection-related reasons.

Section 3(2) of the 1999 Act set out the following categories of persons in respect of whom a deportation order may be made:

a) a person who has served or is serving a term of imprisonment imposed on him or her by a court in the State;

b) a person whose deportation has been recommended by a court in the State before which such person was indicted for or charged with any crime or offence;

c) a person who has been required to leave the State under Regulation 14 of the European Communities (Aliens) Regulations, 1977 (S.I. No. 393 of 1977);

d) a person to whom Regulation 19 of the European Communities (Right of residence for Non-Economically Active Persons) Regulations, 1997 (S.I. No. 57 of 1997) applies;

e) a person whose application for asylum has been transferred to a convention country for examination pursuant to section 22 of the Refugee Act, 1996; 108

f) a person whose application for asylum has been refused by the Minister; ${ }^{109}$

g) a person to whom leave to land in the State has been refused;

h) a person who, in the opinion of the Minister, has contravened a restriction or condition imposed on him or her in respect of landing in or entering into or leave to stay in the State;

i) a person whose deportation would, in the opinion of the Minister, be conducive to the common good. ${ }^{110}$

There are a number of qualifications to the Minister's power to make a deportation order under section 3 of the 1999 Act. Section 3(6) provides that, in considering the making of a deportation order, the Minister must have regard to the following factors:

a) the age of the person;

b) the duration of residence in the State of the person;

c) the family and domestic circumstances of the person;

d) the nature of the person's connection with the State, if any;

e) the employment (including self-employment) record of the person;

f) the employment (including self-employment) prospects of the person;

g) the character and conduct of the person both within and (where relevant and ascertainable) outside the State (including any criminal convictions);

h) humanitarian considerations;

i) any representations duly made by or on behalf of the person;

j) the common good;

k) considerations of national security and public policy. under the Dublin III Regulation is now provided for by The European Union (Dublin System) Regulations 2014 (Stanley, 2017). specifically for unsuccessful international protection applicants (Stanley, 2017). 
Each factor allows for a wide range of circumstances to be taken into account. The meaning of 'humanitarian considerations' in section 3(6)(h) of the 1999 Act is not defined. Typically, such considerations pertain to a person's personal rights and private life matters (Stanley, 2017). Section 3(6) also ensures consideration of the constitutional and European Convention on Human Rights (ECHR) right to family life in the decision to make a deportation order (Stanley, 2017). The 'humanitarian considerations' and 'family and domestic circumstances' grounds may encompass a situation where a person has a need for protection which does not fall within the definition of a refugee, or subsidiary protection, and thus acts as a form of complementary protection (Murphy, 2005).

In addition to the factors set out in section 3(6) of the 1999 Act, section 3(1) of that Act states that the Minister's power to make a deportation order is subject to the prohibition of refoulement set out in section 3A of the 1999 Act. Section 3A of the 1999 Act, as inserted by section 95 of the Withdrawal of the United Kingdom from the European Union (Consequential Provisions) Act 2019, provides that a person shall not be expelled or returned in any manner whatsoever to the frontier of a territory where, in the opinion of the Minister, (a) the life or freedom of the person would be threatened for reasons of race, religion, nationality, membership of a particular social group or political opinion, or, (b) there is a serious risk that the person would be subjected to the death penalty, torture or other inhuman or degrading treatment or punishment. ${ }^{111}$

The making of a deportation order is also subject to constitutional and international human rights arising, including, among other rights, personal rights under Article 40.3 of the Constitution, including the right to life, rights arising as a result of the obligations of the Minister pursuant to section 3(1) of the European Convention on Human Rights Act 2003 (as amended), including the right to life under Article 2 of the European Convention on Human Rights (ECHR) and the prohibition of torture or inhuman or degrading treatment or punishment under Article 3 of the ECHR, as well as the prohibition of torture under the Criminal Justice (United Nations Convention Against Torture) Act 2000 (as amended) (Stanley, 2017).

Section 3(3) of the 1999 Act provides that when the Minister proposes to make a deportation order, the Minister must notify the person of the proposal to make a deportation order and the reasons for doing so. The person concerned is notified by way of what has become colloquially known as a '15-day letter', which sets out three options: to make representations to the Minister against the making of a deportation order; to leave the State voluntarily; or to consent to the making of a 
deportation order, with one of these options to be exercised within 15 working days. ${ }^{112}$ Following the consideration of any representations made by an applicant, the Minister decides whether or not the applicant should become the subject of a deportation order.

Where the Minister decides against the making of a deportation order in a particular case, they may use their discretion to instead grant the person leave to remain. Section 3 of the 1999 Act is silent regarding the Minister's powers if a decision not to deport is taken. Section 3 does not provide that leave to remain must be granted in such cases; neither does it provide the basis for granting leave to remain. While section 3 of the 1999 Act does not provide for a statutory application for leave to remain, and the section does not explicitly provide the Minister with a power to grant leave to remain, where the Minister decides not to make a deportation order, an individual is deemed in practice to have been granted 'leave to remain' in lieu of deportation (Stanley, 2017).

The precise legal basis for the granting of leave to remain in such cases has been the subject of recent judgments in the High Court and Supreme Court. Clark J. held in the High Court in Jamali v Minister for Justice and Equality that section 4 of the 2004 Act is the source of the granting of leave to remain following a decision not to deport. ${ }^{113}$ However, Stanley (2017) and Casey (2015) called into question the High Court's interpretation, arguing that the basis of the granting of leave to remain lies in the Minister's power to grant permissions as part of the executive function of the State, independent of statutory provisions. Casey (2015), in referring to the Supreme Court judgment in Sulaimon $v$ Minister for Justice and Equality, stated that the granting of permission to remain lies in the Minister for Justice and Equality's 'inherent power to consider and determine an application for residency independent of any statutory scheme'. ${ }^{114}$ Most recently, in a judgment delivered in the High Court in PF v Minister for Justice and Equality, Keane J. stated that the High Court in Jamali had erred in law and reiterated the Supreme Court in Sulaimon in stating that there is a general power vested in the Minister to grant a non-national permission to be in the State derived directly from the executive power of the State, independent of the powers contained in section 4 of the 2004 Act. ${ }^{115}$ INIS confirmed that those who are granted leave to remain are granted permission under the inherent executive discretion of the Minister, rather than on a legislative basis. ${ }^{116}$

The decision to grant leave to remain following a decision not to deport is made by the Repatriation Division of the Department of Justice and Equality. ${ }^{117}$ Where a

Immigration Act 1999, s 3(4).

[2013] 1 IR 609.

Sulaimon v Minister for Justice and Equality [2012] IESC 63.

[2019] IEHC 369. See also Bundhooa v Minister for Justice and Equality [2018] IEHC 756.

Correspondence with the Department of Justice and Equality, May 2019.

Correspondence with the Department of Justice and Equality, May 2019. 
decision is made to grant leave to remain in the State, this decision is conveyed in writing to the successful applicant and to their legal representative, if they are known. This communication advises the successful applicant of the conditions attaching to their permission to remain in the State, the circumstances under which this permission can be revoked, the means by which they can become registered in the State, and the process involved in applying for the renewal of the permission to remain.

This communication does not advise the successful applicant of the specific reasons for the granting of leave to remain, which could be based on any combination of the factors listed above as relevant to the Minister's decision. The Minister is not obliged to provide reasons for the grant of leave to remain. ${ }^{118}$ Accordingly, a recipient of leave to remain will not know whether the reason for the grant of leave to remain relates to a non-refoulement and international protection claim, where applicable, or to other matters.

There is no appeal in the event of a negative decision following representations (which will result in the making of a deportation order); however, it is possible to apply for revocation of a deportation order under section 3(11) of the 1999 Act, which, if successful, may result in a grant of leave to remain. A person seeking revocation of a deportation order must present the Minister with new information - additional to that which was available at the time of issuing the deportation order - such as information on materially changed circumstances or about changed conditions in the country of origin (Sheridan, 2017b), ${ }^{119}$ or significant life events on the part of the relevant applicant. Unlike under the proposal to deport procedure, section 3(11) of the 1999 Act does not set out the procedure for the making of an application or the matters the Minister must consider when deciding whether or not to revoke a deportation order. However, in Sivsivadze $v$ Minister for Justice, the Supreme Court held that when deciding whether to revoke a deportation order under section 3(11) of the 1999 Act the Minister must have regard to all relevant factors, including any rights protected by the Constitution or the ECHR. ${ }^{120}$ In IRM v Minister for Justice and Equality (No. 2), the High Court held on the basis of case law, including Sivsivadze, that the matters that must be considered by the Minister are any representations by the applicant, as well as any change of circumstances since the original decision that engages a legal provision that would have the effect of rendering the deportation unlawful by reason of an actual or prospective breach of the applicant's rights. ${ }^{121}$

Alternatively, an application may be made to quash a deportation order by way of judicial review. If the courts quash a deportation order by way of judicial review, this does not prevent the Minister from issuing a fresh decision on whether or not 
to make a deportation order. In other words, the court does not have the final say on whether a person should be deported or granted leave to remain.

Up to 31 December 2016, unsuccessful international protection applicants may have sought leave to remain following a decision to not make a deportation order under section 3 of the 1999 Act; however, save for those cases which had been commenced but not finalised under the historical international protection regime, this is no longer the case following the enactment of the 2015 Act (see Section 2.4.1 below). The provisions of the 1999 Act and the opportunity to make representations to the Minister to grant leave to remain in lieu of deportation continue to apply to section 3 notifications of intention to deport issued to persons other than unsuccessful applicants for international protection (Stanley, 2017).

\subsubsection{Unsuccessful international protection applicants}

Prior to the enactment of the 2015 Act, the provisions of the 1999 Act applied to persons who had submitted an unsuccessful application for international protection under the Refugee Act 1996, which was in force up to end 2016. However, since the coming into force of the 2015 Act, the procedure around deportation of an unsuccessful international protection applicant has changed. Section 51 of the 2015 Act provides for the making of a deportation order following the receipt of a final negative decision on an application for international protection and permission to remain under the $2015 \mathrm{Act}$, subject to the prohibition of refoulement. ${ }^{122}$ While a deportation order made under section 51 of the 2015 Act is deemed to be a deportation order made under section 3(1) of the 1999 Act, ${ }^{123}$ the issuing of a proposal to deport (the '15-day letter') and 15-day period for making representations no longer apply to unsuccessful international protection applicants.

Nevertheless, the possibility to revoke a deportation order pursuant to section 3(11) of the 1999 Act still applies to deportation orders made under section 51 of the 2015 Act in respect of unsuccessful international protection applicants (see above). person would be threatened for reasons of race, religion, nationality, membership of a particular social group or political opinion, or (b) there is a serious risk that the person would be subjected to the death penalty, torture or other inhuman or degrading treatment or punishment. 
2.4.2 Profile of persons who submitted an international protection application and were granted leave to remain following a decision not to make a deportation order under section 3 of the 1999 Act

Table 2.4 sets out the country of origin of persons who submitted an international protection application and were granted leave to remain following a decision not to make a deportation order under section 3 of the 1999 Act.

As stated earlier in this section (2.4), the grant of leave to remain following a decision not to make a deportation order under section 3 of the 1999 Act does not set out the reasons for which it was granted; thus, it is not possible to say whether the grants of leave to remain in Table 2.4 relate to a non-refoulement and international protection claim or to other matters. 
TABLE 2.4 TOTAL LEAVE TO REMAIN FOLLOWING A DECISION NOT TO MAKE A DEPORTATION ORDER UNDER SECTION 3 OF THE IMMIGRATION ACT 1999 GRANTED TO PERSONS WHO HAD MADE AN INTERNATIONAL PROTECTION APPLICATION BY COUNTRY OF ORIGIN, 2010-2018

\begin{tabular}{|c|c|c|c|c|c|c|c|}
\hline & $\begin{array}{c}\text { Nationality } \\
1\end{array}$ & $\begin{array}{c}\text { Nationality } \\
2\end{array}$ & $\begin{array}{c}\text { Nationality } \\
\mathbf{3}\end{array}$ & $\begin{array}{c}\text { Nationality } \\
4\end{array}$ & $\begin{array}{c}\text { Nationality } \\
5\end{array}$ & Other & Total \\
\hline \multirow[t]{2}{*}{2010} & Nigeria & DRC & Croatia & Pakistan & Albania & & \\
\hline & 52 & 14 & 9 & 7 & 6 & 77 & 165 \\
\hline \multirow[t]{2}{*}{2011} & Nigeria & DRC & Somalia & Zimbabwe & Cameroon & & \\
\hline & 331 & 56 & 29 & 28 & 27 & 278 & 749 \\
\hline \multirow[t]{2}{*}{2012} & Nigeria & DRC & Somalia & Pakistan & Ghana & & \\
\hline & 75 & 47 & 18 & 18 & 17 & 231 & 406 \\
\hline \multirow[t]{2}{*}{2013} & Nigeria & DRC & Zimbabwe & Ghana & Pakistan & & \\
\hline & 118 & 60 & 49 & 36 & 34 & 345 & 642 \\
\hline \multirow[t]{2}{*}{2014} & Nigeria & Pakistan & DRC & Georgia & Ghana & & \\
\hline & 278 & 41 & 28 & 20 & 19 & 261 & 647 \\
\hline \multirow[t]{2}{*}{2015} & Nigeria & Ghana & Pakistan & DRC & Zimbabwe & & \\
\hline & 480 & 69 & 66 & 61 & 53 & 481 & 1210 \\
\hline \multirow[t]{2}{*}{2016} & Nigeria & Pakistan & DRC & Zimbabwe & $\begin{array}{l}\text { South } \\
\text { Africa }\end{array}$ & & \\
\hline & 150 & 47 & 38 & 22 & 17 & 194 & 468 \\
\hline \multirow[t]{2}{*}{2017} & Nigeria & Pakistan & Zimbabwe & Albania & China & & \\
\hline & 46 & 28 & 12 & 11 & 9 & 63 & 169 \\
\hline \multirow[t]{2}{*}{2018} & Nigeria & Albania & Zimbabwe & Malawi & Pakistan & & \\
\hline & 42 & 23 & 20 & 20 & 13 & 102 & 220 \\
\hline
\end{tabular}

Source: Correspondence with RAU, Department of Justice and Equality, May 2019.

Note: $\quad$ DRC $=$ Democratic Republic of the Congo.

Figure 2.5 provides an age breakdown of persons who submitted an international protection application and were subsequently granted leave to remain following a decision not to make a deportation order under section 3 of the 1999 Act. 
FIGURE 2.5 PERSONS GRANTED LEAVE TO REMAIN FOLLOWING A DECISION NOT TO MAKE A DEPORTATION ORDER UNDER SECTION 3 OF THE IMMIGRATION ACT 1999 HAVING PREVIOUSLY SUBMITTED AN INTERNATIONAL PROTECTION APPLICATION, BY AGE, 2010-2018

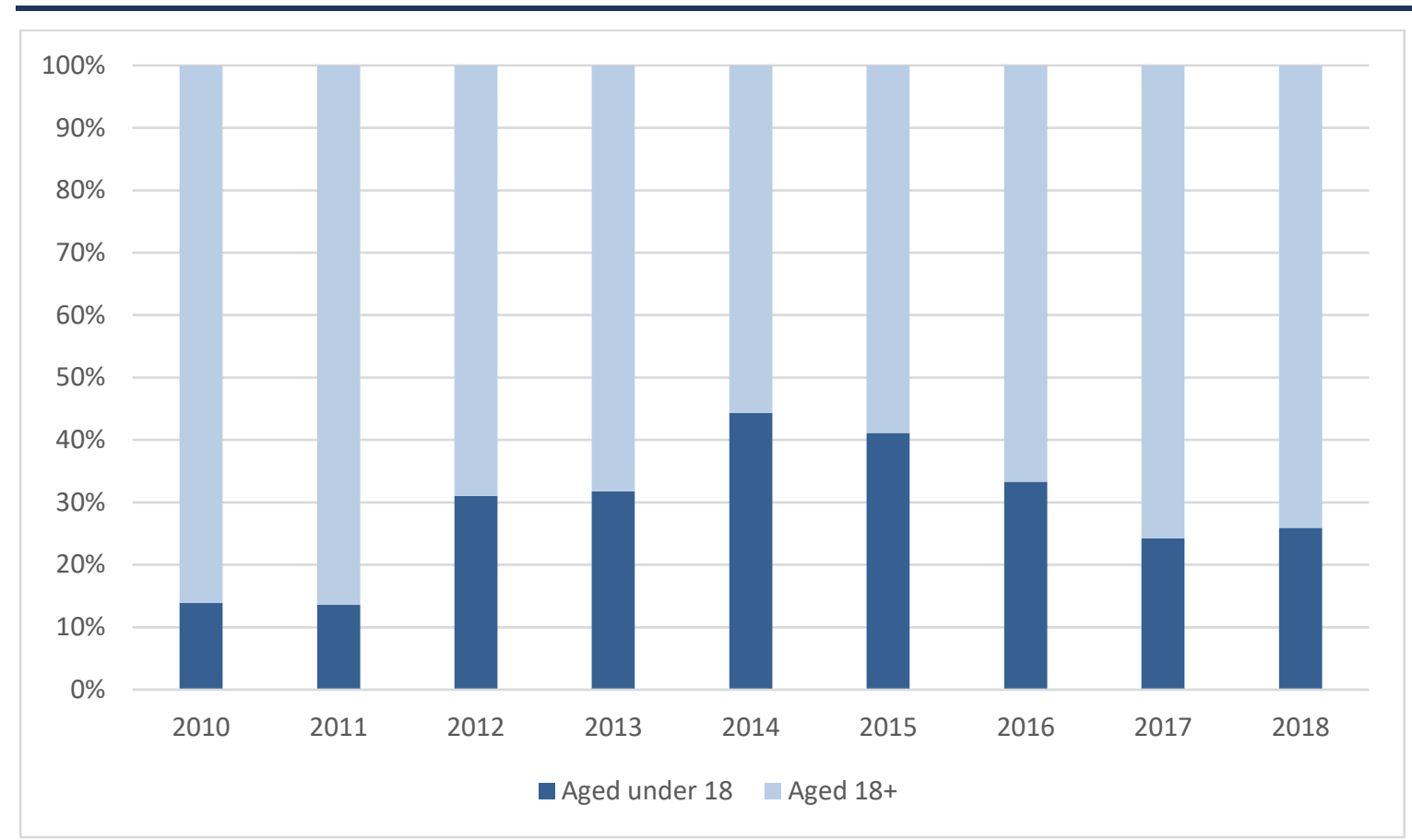

Source: Correspondence with RAU, Department of Justice and Equality, May 2019.

Figure 2.6 provides a gender breakdown of grants of leave to remain over the same period.

FIGURE 2.6 PERSONS GRANTED LEAVE TO REMAIN FOLLOWING A DECISION NOT TO MAKE A DEPORTATION ORDER UNDER SECTION 3 OF THE IMMIGRATION ACT 1999 HAVING PREVIOUSLY SUBMITTED AN INTERNATIONAL PROTECTION APPLICATION, BY GENDER, 2010-2018

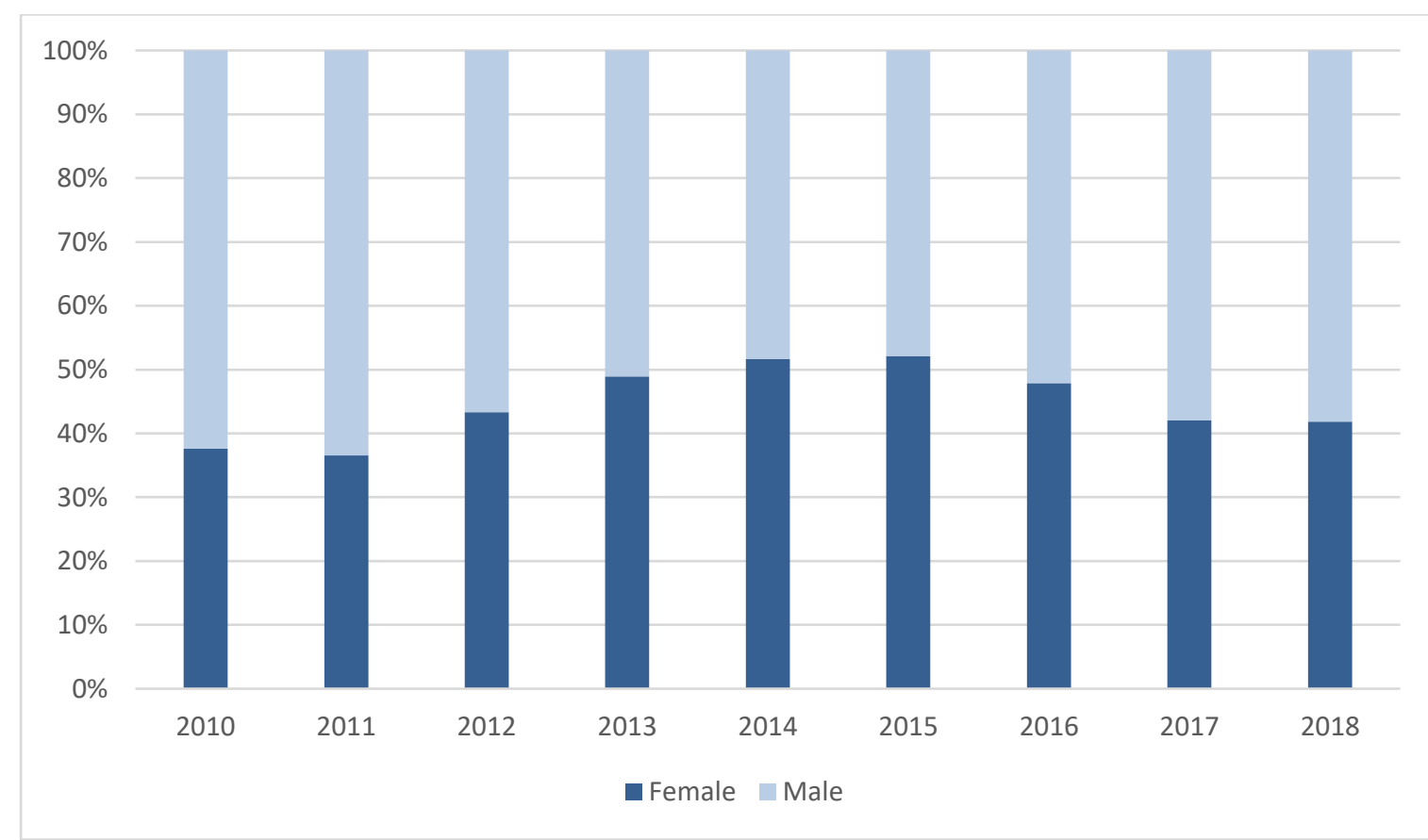

Source: Correspondence with RAU, Department of Justice and Equality, May 2019. 


\subsection{PERMISSION TO REMAIN UNDER SECTION 4 OF THE IMMIGRATION ACT 2004}

The Immigration Act 2004 (the 2004 Act) regulates the entry of non-nationals to the State. Section 4 of the Immigration Act 2004 (the 2004 Act) provides the Minister for Justice and Equality, or an immigration officer on his behalf, with discretion to grant a non-Irish national with permission to land or be in the State and to impose conditions on such permission as he sees fit. The Supreme Court, in the case of Sulaimon $v$ Minister for Justice and Equality, stated that the focus of section 4 of the 2004 Act is 'not to set some general template for all permissions granted, but rather to make provision for the decision of immigration officers at point of entry to the State'. ${ }^{124}$ Officials from the Department of Justice and Equality have indicated that they consider that the discretionary power of the Minister to grant permission to land or be in the State under section 4 of the Immigration Act 2004 confers a necessary discretion to allow the Minister to deal with individual cases (Stanley et al., 2010).

An individual who is already in the State without permission cannot subsequently apply for permission under section 4(1), but a person who has been granted permission under section 4(1) may apply under section 4(7) of the 2004 Act for that permission to be varied or renewed by the Minister (Stanley et al., 2010). ${ }^{125}$

While the legislation was not established specifically for protection-related matters, section 4 of the Immigration Act 2004 is a statutory mechanism that may provide a means to grant an individual with a protection need permission to be or remain in the State (Stanley et al., 2010). As stated in this report (in Section 2.2 and Section 2.3 respectively), permission to remain granted under section 49 of the 2015 Act and permission to remain given to a person in accordance with section 50 of the 2015 Act is deemed to be permission to remain under section 4 of the 2004 Act; accordingly, the provisions of the 2004 Act apply to persons granted such permissions.

Section 4 of the Immigration Act 2004 does not refer to any specific procedure for making an application. Such applications are generally made in writing to the Minister setting out the grounds in support of the application. The Minister will then issue a written decision in respect of the application. The legislation does not set out any time limits for the determination of an application.

Where a decision is made to grant permission, this decision is conveyed in writing to the successful applicant and to their legal representative, if they are known. This communication advises the successful applicant of the conditions attaching to their permission to remain in the State, the circumstances under which this permission 
can be revoked, the means by which they can become registered in the State, and the process involved in applying for the renewal of the permission to remain. This communication may not advise the successful applicant of the specific reasons for the grant of permission.

While there has been much judicial debate around the operation of section 4 of the 2004 Act, there are no published guidelines regarding the application of the provisions in section 4. The decision of whether to grant permission to remain is made by the Residence Unit of the Department of Justice and Equality. Representatives of the Department of Justice and Equality have confirmed that there have been instances where the Minister has granted migrants leave to remain under section 4 of the Immigration Act 2004 but that this mechanism has not been used at any time to grant permission to remain to anyone with international protection needs or who is at risk of refoulement (Stanley et al., 2010).

\subsection{SYRIAN HUMANITARIAN ADMISSION PROGRAMME (SHAP)}

From 14 March to 30 April 2014, Ireland operated a one-off family sponsorship scheme known as the Syrian Humanitarian Admission Programme (SHAP). SHAP was an administrative scheme established by ministerial discretion to offer temporary residence to vulnerable persons in Syria or persons who had fled from Syria to neighbouring countries and who had close family members residing in the State. Eligible sponsors were Syrian nationals lawfully resident in Ireland and naturalised Irish citizens of Syrian birth (Arnold and Quinn, 2016).

The Family Reunification Unit in the Irish Naturalisation and Immigration Service (INIS) had responsibility for receiving and processing SHAP applications. Priority was given to persons deemed to be the most vulnerable, and who did not present concerns relating to community safety or state security; examples of potentially eligible individuals include elderly parents, children, mothers and their children, single women and girls at risk, and disabled persons. ${ }^{126}$ SHAP beneficiaries were granted permission to remain on a temporary basis for up to two years, in the form of a SHAP authorisation stamp. Out of all applications made on behalf of 308 persons, 114 persons were granted permission to remain in Ireland in 2014 and a further five were granted permission in 2015 (Arnold and Quinn, 2016).

SHAP is an example of a private refugee sponsorship scheme and was the first of its kind in Ireland (Arnold and Quinn, 2016). Following the introduction of SHAP, NGOs advocated for similar private sponsorship or humanitarian admission programmes to be established in Ireland to complement the state-led resettlement programme and the international protection procedure. As part of proposals 
regarding safe and legal pathways to Ireland published in 2016, the Irish Refugee Council suggested that a programme similar to SHAP be explored with flexible eligibility criteria that extends beyond Syrian nationals, to include people fleeing persecution or conflict from other countries (Irish Refugee Council, 2016). As part of its Safe Passage campaign, and in a submission to the Joint Oireachtas Committee on Justice and Equality, Nasc recommended the introduction of a humanitarian admission programme modelled on SHAP, which would allow Irish citizens, community and faith-based groups, charities or NGOs to support a family reunification application for extended family members fleeing conflict zones (Nasc, 2016). The Joint Oireachtas Committee called for a humanitarian admission programme for refugees from Syria and other countries who have immediate or extended family members displaced or in conflict zones, taking into account what was learned from SHAP (Houses of the Oireachtas, 2017). The Irish Refugee and Migrant Coalition also recommended that the Government establish a familylinked humanitarian admission programme to allow Irish citizens, beneficiaries of international protection or legal residents to sponsor family reunification for extended family members fleeing conflict zones (Irish Refugee and Migrant Coalition, 2017). Since the conclusion of SHAP, the Government introduced IHAP (see Section 2.1.3 of this report) and the CSI initiative (see Section 2.1.4 of this report). 


\section{CHAPTER 3}

\section{Content of national statuses}

As discussed in Chapter 2, the statuses examined in this report are diverse in terms of their policy objectives, legal basis and determination procedure. As a result, the entitlements and conditions attached to each status differ.

While the entitlements that flow from international protection and programme refugee status are set out in international, EU and domestic law, the content of the other national statuses that may be granted to a person with a protection need are subject to the discretion of the Minister. In particular, rights and entitlements, including in the areas of education, employment, family reunification and length of time for which permission is granted, may vary significantly among the various statuses.

This chapter first sets out the content of protection afforded to holders of international protection and standards applicable to beneficiaries of temporary protection. This is followed by a description of the content of each national status, including the terms of the residence permission granted and the rights to which the holder of the status is entitled (such as access to employment, education, social welfare, healthcare, family reunification, accommodation and the provision of targeted integration supports where relevant).

Table 3.1 provides a brief summary of the entitlements for holders of each status and the conditions attached to the residence permission granted to status holders. Conditions attached to the statuses, unless specified in legislation, may vary at the discretion of the Minister. 
TABLE 3.1
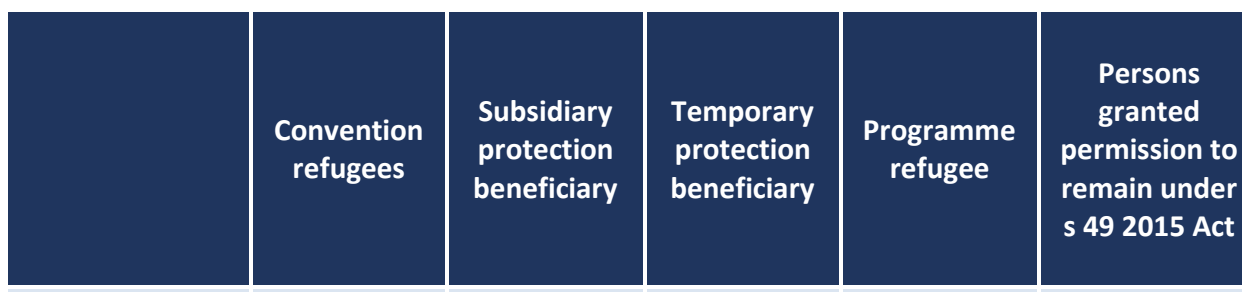

Persons

granted

leave to

remain

under $\mathbf{S}$

1999 Act

\begin{tabular}{l|l|}
\hline $\begin{array}{l}\text { Rights set out } \\
\text { in legislation }\end{array}$ & Yes \\
\hline
\end{tabular}

Permission to

Yes

Yes

Yes

No

No

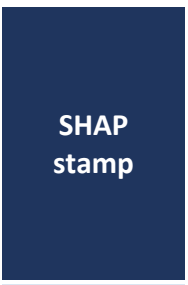

remain +

Stamp 4;

Stamp 4; 1 year,

Stamp 4;

duration

3 years

3 years

renewable

May be less

than 3 years

\begin{tabular}{|c|c|c|c|c|}
\hline Naturalisation & 3 years & 5 years & 5 years & 3 years \\
\hline $\begin{array}{l}\text { Family } \\
\text { reunification }\end{array}$ & Yes & Yes & No & Yes \\
\hline $\begin{array}{l}\text { Access to the } \\
\text { labour market }\end{array}$ & Yes & Yes & Yes & Yes \\
\hline
\end{tabular}

\section{At Minister's}

discretion; in

practice

Stamp 4

5 years

No

At Minister's

discretion; in

practice,

granted

Stamp 4

which allows

holder to

access

employment

At

Minister's

discretion;

depends on

Yes

stamp

received

\section{Eligible for}

state support

for third-leve

Yes

Yes

No

Yes

No

Yes

No

education

\begin{tabular}{|c|c|c|c|c|c|c|c|}
\hline $\begin{array}{l}\text { Access to social } \\
\text { welfare and } \\
\text { healthcare }\end{array}$ & Yes & Yes & Yes & Yes & $\begin{array}{l}\text { At Minister's } \\
\text { discretion; in } \\
\text { practice, } \\
\text { granted } \\
\text { Stamp } 4 \\
\text { which allows } \\
\text { holder to } \\
\text { apply for } \\
\text { social welfare } \\
\text { and public } \\
\text { healthcare }\end{array}$ & $\begin{array}{l}\text { At } \\
\text { Minister's } \\
\text { discretion; } \\
\text { depends on } \\
\text { stamp } \\
\text { received }\end{array}$ & $\begin{array}{l}\text { Limited to } \\
\text { emergency } \\
\text { medical } \\
\text { services }\end{array}$ \\
\hline $\begin{array}{l}\text { Targeted } \\
\text { orientation and } \\
\text { integration } \\
\text { supports }\end{array}$ & No & No & No & Yes & No & No & No \\
\hline
\end{tabular}

Note: In order to avail of state financial support for third-level education under the Free Fees Initiative, eligible status-holders must also satisfy a residence condition of 3 years.

In general non-EEA nationals who are legally resident in the State may apply for and access social welfare payments and public healthcare in the same way that Irish nationals do, i.e. provided that all qualifying conditions, such as the Habitual Residence Condition for social assistance payments, or the Ordinarily Resident Condition for free public health services, are satisfied (see Quinn et al., 2014). 


\subsection{INTERNATIONAL PROTECTION AND TEMPORARY PROTECTION STATUS}

The rights of persons granted international protection in Ireland are set out in the 2015 Act, giving effect to the minimum standards for the content of international protection set out in the 2004 Qualification Directive. Section 53(c) states that refugees and subsidiary protection beneficiaries are entitled to reside in the State. Section 54(1) states that they must be given permission to remain in the State for at least three years. Section 53(a) of the 2015 Act states that international protection beneficiaries are entitled to seek and enter employment, to engage in any business, trade or profession and to have access to education and training in the State on the same basis as Irish citizens. Section 53(b) states that they are also entitled to receive the same medical care and the same social welfare benefits, subject to the same conditions, as an Irish citizen. Pursuant to section 53(d), they also have the same rights of travel in, to or from the State as Irish citizens. International protection beneficiaries also have a statutory entitlement pursuant to section 56(1) of the 2015 Act to apply to the Minister for reunification with certain family members.

The EU Temporary Protection Directive has not been activated to date. However, in the event of the Directive being activated, and Member States being authorised to grant persons temporary protection status, the 2015 Act sets out the conditions that would apply to a non-EU national granted temporary protection in Ireland. Section 60(6) of the 2015 Act states that the Minister shall give a person granted temporary protection permission to remain in the State. Permission to remain in the State for temporary protection beneficiaries is granted for one year, and may be renewed. ${ }^{127}$ Temporary protection beneficiaries are entitled to seek and enter employment, engage in any business, trade or profession and have access to education and training in the State on the same basis as Irish citizens. ${ }^{128}$ They are entitled to receive, subject to the same conditions as Irish citizens, the same medical care and social welfare benefits as those to which Irish citizens are entitled. ${ }^{129}$ Temporary protection beneficiaries have the same rights of travel in the State as Irish citizens. ${ }^{130}$

\subsection{PROGRAMME REFUGEE STATUS}

Programme refugees, like international protection beneficiaries or 'Convention refugees', are generally provided with rights and privileges similar to those of Irish citizens. Section 59(2) of the International Protection Act 2015 provides that the provisions relating to certain rights, permission to remain and travel documents 
that apply to a 'qualified person', or a beneficiary of international protection, also apply to programme refugees 'as if the programme refugee is a qualified person'.

\subsubsection{Permission to remain}

Section 54(1) of the 2015 Act provides that a beneficiary of international protection shall be given permission to remain in the State for a specified period of not less than three years. However, permission granted to programme refugees to remain in the State may be for a specified period of less than three years. ${ }^{131}$ Permission to remain in the State under section 54 of the 2015 Act is renewable unless compelling reasons of national security or public order otherwise require. ${ }^{132}$ The legislation does not stipulate the validity of the residence permit nor its validity after renewal; this is a matter of ministerial discretion (Arnold and Quinn, 2016).

A person granted programme refugee status is issued with a Stamp 4 residence permission (Gusciute et al., 2016) allowing them to seek and enter employment.

At the time of the drafting of the 2015 Act, the Irish Refugee Council expressed concern that the Minister can grant programme refugees permission to remain for a period of less than three years. The Irish Refugee Council stated that, as resettlement is a durable solution, persons granted programme refugee status should be granted permission to remain to the same extent as other persons granted Convention refugee status - for periods of three years or more, on a renewable basis (Irish Refugee Council, 2011).

Section 15 of the Irish Nationality and Citizenship Act 1956 (as amended) (the 1956 Act) provides that a person may apply for naturalisation as an Irish citizen where they have resided in the State for four of the previous five years, plus one year's continuous residence in the State immediately prior to the application. However, section $16(\mathrm{~g})$ of the 1956 Act provides that the Minister may, in his absolute discretion, grant an application for naturalisation even though the conditions (including minimum legal residence) are not met, where the person is a refugee or a stateless person. Currently, two years of the five-year residence required in order to apply for citizenship can be waived in the case of Convention and programme refugees. Refugees must have resided in the State for three years immediately prior to the application (Stanley et al., 2010). 


\subsubsection{Accommodation}

The type of accommodation to which a programme refugee has access depends on the programme through which they have been resettled in Ireland.

Programme refugees, like international protection beneficiaries, are eligible to be considered for social housing support on the same basis as Irish citizens (Gusciute et al., 2016; Department of Environment, Community and Local Government, 2012), including through the Housing Assistance Payment scheme. ${ }^{133}$

\section{Programme refugees resettled as part of the Irish Refugee Protection Programme (IRPP)}

Programme refugees arriving in Ireland through the Irish Refugee Protection Programme (IRPP) - under the Irish Refugee Resettlement Programme (IRRP) - are initially provided with temporary accommodation in emergency reception and orientation centres (EROCS) prior to settlement in communities around the country. EROCs were established in 2016 as part of commitments under the IRPP specifically relating to accommodating persons relocated or resettled in Ireland. At present, there are two EROCs in operation: one in Dungarvan, County Waterford, and the other in Ballaghadereen, County Roscommon. ${ }^{134}$ In addition, the IRPP unit has the use of dedicated EROC places within the Mosney Direct Provision centre in County Meath. ${ }^{135}$ A resettled refugee's stay in an EROC is intended to be for a period of eight to 12 weeks, though this period may be longer, in particular due to housing shortages (Government of Ireland, 2018). The IRPP unit reported that resettled refugees spend eight months to one year in an EROC before being resettled in the community (Arnold et al., 2018).

Following an initial stay in an EROC, resettled refugees are housed in independent accommodation around the country. Receiving communities are selected by the Department of Justice and Equality, in consultation with the Inter-Departmental Working Group on Refugee Resettlement and Integration, with membership comprising representatives of mainstream government departments, the Health Service Executive (HSE) and SOLAS. ${ }^{136}$ When selecting a receiving community, the

The Housing Assistance Payment is a payment made by local authorities for people with long-term housing needs who qualify for social housing support. A monthly payment is made directly to the landlord, with the tenant paying a contribution towards rent to the local authority. See: Housing Assistance Payment, 'Housing Assistance Payment scheme', http://hap.ie/.

A third EROC in Monasterevin, County Kildare, was in operation up to August 2018. It was subsequently contracted as a Direct Provision centre. Parliamentary Question [35672/18], 7 September 2018, available at http://www.justice.ie/en/JELR/Pages/PQ-07-09-2018-450. 
Department of Justice and Equality considers if all services required by programme refugees will be available to them in that community (Arnold and Quinn, 2016).

Resettled programme refugees may access housing in the private rental sector and social housing, both of which are provided and sourced by the local authorities. The Irish Red Cross manages a programme to secure accommodation for persons arriving in Ireland under the IRPP, including resettled refugees, through pledges from members of the public (Arnold et al., 2018). ${ }^{137}$ Housing associations such as Clúid Housing also provide social housing for resettled refugees with the aid of grants (Arnold and Quinn, 2016). Securing EROCs in addition to long-term housing in the community for resettled refugees has been identified as a challenge in the context of the wider housing crisis in Ireland (Arnold and Quinn, 2016; Arnold et al., 2018).

\section{Programme refugees under the IRPP Humanitarian Admission Programme (IHAP)}

Persons who arrived under IHAP are expected to reside with the sponsor or in accommodation provided by the sponsor. Priority is given to sponsors who can accommodate beneficiaries. ${ }^{138}$

\section{Programme refugees under Community Sponsorship Ireland (CSI)}

Programme refugees arriving in Ireland under the Community Sponsorship Ireland (CSI) initiative are housed on arrival in the destination community, rather than in EROCs. The group sponsoring the refugees is required to commit to ensuring housing has been identified and is available on arrival for 24 months. Housing options may include donated housing, purchase of property, rent payment or supplements to the Housing Assistance Payments scheme (Department of Justice and Equality, 2019a). The Department of Justice and Equality (2019a) noted that finding homes for refugees will be one of the most pressing challenges under the CSI initiative in the context of pressures experienced in the Irish housing market.

\section{Unaccompanied minors granted programme refugee status under the Calais Special Project}

Unaccompanied minors that were granted programme refugee status following arrival in Ireland under the Calais Special Project were referred to the Social Work Team for Separated Children Seeking Asylum, part of Tusla, Child and Family Agency, which is responsible for the care of unaccompanied minors in Ireland. Housing for all unaccompanied minors, regardless of their status, may consist of 
foster care, supported lodgings or residential accommodation (Groarke and Arnold, 2018).

\subsubsection{Orientation and integration supports}

In addition to accessing mainstream supports on the same basis as Irish nationals, programme refugees may have access to additional orientation and integration supports specifically targeted to their needs. The type of orientation and integration supports to which a programme refugee has access is dependent on the programme through which they have arrived in Ireland. Programme refugees resettled under the IRRP and IRPP, as well as the CSI initiative, are the only group to have access to targeted integration supports (Gusciute et al., 2016; Arnold et al., 2019). This contrasts with the position of individuals who came through the international protection process, for whom targeted integration services are not provided by the State.

\section{Programme refugees resettled as part of the Irish Refugee Protection Programme (IRPP)}

Following arrival in Ireland, resettled programme refugees are provided with an orientation programme while residing in EROCs. The programme, which is provided by Education and Training Boards (ETBs) in cooperation with the Department of Justice and Equality, is tailored to the needs of each group and covers a wide range of areas such as language skills and information on rights and entitlements, the Irish education system, employment and life in Ireland (Gusciute et al., 2016). Services and crèche facilities are available to ensure adult refugees can participate in the programme. A separate induction programme is provided for children to prepare them for mainstream education. Once private housing is arranged, resettled programme refugees can avail of a 12-month period of support provided by a resettlement support worker at local level to facilitate access to mainstream services. Programme refugees can avail of an English language programme of up to 20 hours tuition per week for a period of one year to 18 months (Arnold and Quinn, 2016).

Kinlen (2011), Pestova (2017) and Arnold et al. (2019) have observed that despite the fact that those granted international protection status and those resettled to Ireland and granted programme refugee status share a similar status and similar entitlements, official orientation and integration programmes offered to resettled programme refugees are not extended to those who arrive spontaneously. Arnold et al. (2019) noted that tailored orientation classes had been provided to both spontaneous and resettled refugees up to 2012. However, the programme in question ceased as the Government argued that spontaneous refugees had access to existing mainstream services through ETBs (McGinnity et al., 2013). While emphasising that there may be differences regarding the experiences and protection needs of individuals within each group, commentators have expressed concern at the differentiation of integration supports provided to resettled 
programme refugees when compared to those refugees who have come through the international protection process, questioning whether the difference in approach is proportionate (Kinlen, 2011; Pestova, 2017). The Jesuit Refugee Service Ireland stated that a two-tier system of accommodation and integration supports between resettled refugees and people applying through the international protection process has emerged. They recommended a consistent model across all categories of persons with status (Quinn and Moriarty, 2018). Arnold et al. (2019) and Ní Raghallaigh et al. (2016) also recommend providing access for both programme refugees and persons exiting Direct Provision to targeted integration supports, such as through the expansion of the programme provided to resettled programme refugees. Research conducted by the United Nations High Commissioner for Refugees (UNHCR, 2013) found some stakeholders were of the view that international protection applicants should be provided with an orientation programme similar to that offered to programme refugees to facilitate integration and access to information once international protection is granted. UNHCR recommended that good practices in place for resettled programme refugees should be extended to persons granted international protection (2013).

\section{Programme refugees under Community Sponsorship Ireland (CSI)}

Those who are sponsoring programme refugees arriving in Ireland through the CSI initiative are responsible for providing orientation support, including registering the refugees with essential state services in the areas of education, employment, health and social protection. Sponsors are required to set out their plans for supporting the sponsored programme refugees in a settlement plan, through provision of financial and non-financial goods and services to enhance integration into the community. Supports can include: exceptional needs or specialist costs for physical, mental and/or dental health; transport; interpretation/translation; language training; employment preparation and job seeking; start-up needs such as household supplies and furnishings; clothing; cultural and social activities; access to religious activities; and access to education (Department of Justice and Equality, 2019a).

\section{Programme refugees under the IRPP Humanitarian Admission Programme (IHAP)}

Unlike the case of resettled programme refugees, there are no targeted orientation or integration supports specifically for non-EEA nationals granted programme refugee status under IHAP. IHAP beneficiaries may access mainstream integration services on the same basis as Irish nationals.

\section{Unaccompanied minors granted programme refugee status under the Calais Special Project}

In contrast to persons resettled to Ireland under the IRRP, unaccompanied minors that were granted programme refugee status under the Calais Special Project are not placed in EROCs and do not avail of targeted orientation and integration 
supports provided to resettled programme refugees. Instead, as is the case for all unaccompanied minors arriving in Ireland, they are referred to the Social Work Team for Separated Children Seeking Asylum, which is part of Tusla, Child and Family Agency. Following this, they are assigned a social worker and placed in a care arrangement or reunited with family (Groarke and Arnold, 2018). Social workers and residential or foster carers provide orientation and integration supports to unaccompanied minors placed in their care (Groarke and Arnold, 2018; Ní Raghallaigh et al., 2019).

\subsubsection{Employment, education, medical care and social welfare}

Programme refugees are entitled 'to seek and enter employment, to engage in any trade or profession and to have access to education and training in the State in the like manner and to the like extent in all respects as an Irish citizen' ${ }^{139}$

Programme refugees are eligible for financial support under the Free Fees Initiative in order to access third-level education on the same basis as Irish citizens, provided certain residence conditions are met. Programme refugees must have resided in Ireland for three of the five years prior to commencing a third-level programme in order to be granted support. ${ }^{140}$

Programme refugees are also entitled to the same medical care and social welfare benefits as those to which Irish citizens are entitled, provided that all qualifying conditions are satisfied (Quinn et al., 2014). ${ }^{141}$

Supports in accessing employment, education, social welfare and medical care are also provided to certain groups of programme refugees.

\section{Programme refugees resettled as part of the Irish Refugee Protection Programme (IRPP)}

Inter-agency working groups established in each receiving community and led by the local authority are responsible for ensuring resettled programme refugees are linked with services, including schools and general practitioners (GPs). In most resettlement communities, local authorities have sub-contracted resettlement support programmes to NGOs or other community organisations as implementing partners, who assign resettlement support workers to deliver supports post-arrival (Ní Raghallaigh et al., 2019).

\footnotetext{
139 International Protection Act 2015, s 53(a).

140 Higher Education Authority, 'Free Fees Initiative', http://hea.ie/funding-governanceperformance/funding/studentfinance/course-fees/. 
Medical screening is provided to programme refugees resettled under the IRPP following arrival in Ireland and a GP is assigned to individuals and families to ensure immediate medical needs are met (Arnold and Quinn, 2016). ${ }^{142}$ Resettled refugees are also assisted in applying for a medical card (Arnold and Quinn, 2016).

Resettled programme refugees are assisted in attending the Department of Employment Affairs and Social Protection to apply for a public services card and to apply for a means-tested social welfare payment appropriate to their circumstances. Resettled programme refugees receive a supplementary welfare allowance, which is a weekly allowance for persons who do not have enough means to meet their needs. However, during the orientation period in an EROC, resettled programme refugees are only entitled to access the same weekly allowance available to international protection applicants residing in Direct Provision centres. Once the orientation period concludes, a resettled programme refugee may access the full allowance rate, unless they have substantial funds to support themselves (Gusciute et al., 2016).

Access to education for children residing in EROCs varies; children in some EROCs attend mainstream primary and post-primary schools while others attend on-site primary and post-primary level classes administered by ETBs. Most children transition to mainstream education once resettled in the local community (Ní Raghallaigh et al., 2019).

\section{Programme refugees under Community Sponsorship Ireland (CSI)}

The groups sponsoring programme refugees arriving in Ireland through the CSI initiative are responsible for assisting those refugees to sign on with a GP and dentist, as well as mental health and other specialist services where required. Assistance must also be provided to refugees to register for a personal public service (PPS) number, to register their children with local schools, to arrange English language tuition for adults and to attend their local Intreo office following arrival (Department of Justice and Equality, 2019b).

\section{Unaccompanied minors granted programme refugee status under the Calais Special Project}

As is the case for all unaccompanied children in the care of the Tusla's Social Work Team for Separated Children, unaccompanied minors that arrived under the Calais Special Project are accompanied by their social worker for an initial health screening and to a GP for a general check-up and consultation following arrival (Groarke and Arnold, 2018; Ní Raghallaigh et al., 2019). Unaccompanied minors in the care of Tusla are entitled to a medical card, which provides for access to public health services free of charge (Groarke and Arnold, 2018). The Social Work Team for Separated Children also refer the child to the City of Dublin Education and 
Training Board's Youth and Education Service for Refugees and Migrants (YES) for an assessment prior to their entry into mainstream education. Based on the assessment, the unaccompanied minor may then be placed in the YES Migrant Access Programme (MAP), which is a transition programme to prepare migrant children for mainstream education or training in Ireland. Following participation in MAP, unaccompanied minors may transition to mainstream education or other training options (Groarke and Arnold, 2018; Ní Raghallaigh et al., 2019).

\subsubsection{Family reunification}

The International Protection Act 2015 does not provide for family reunification for programme refugees. In practice, the Department of Justice and Equality has accepted applications from programme refugees for family reunification on an equivalent basis to Convention refugees (Arnold and Quinn, 2017).

The categories of eligible family members are:

- spouse;

- civil partner;

- where the sponsor is, on the date of application, under 18 years and not married, his or her parents and their children who are under 18; and

- a child of the sponsor who is under 18 and not married. ${ }^{143}$

The duration of a residence permission granted to a family member of a programme refugee is subject to the discretion of the Minister. However, a family member must be given permission for a specified period of not less than one year and, in case of renewal, of not less than two years. ${ }^{144}$

\subsubsection{Travel}

Like beneficiaries of international protection, a programme refugee is entitled to the same rights of travel in, to or from the State as those to which Irish citizens are entitled. ${ }^{145} \mathrm{~A}$ programme refugee is entitled to a travel document on application to the Minister. ${ }^{146}$ However, the Minister may not issue a travel document if the person has not provided information the Minister reasonably requires for the purposes of their functions in relation to issuing travel documents, or if the Minister considers that to do so would not be in the interests of national security, public security, public health or public order or would be contrary to public policy. ${ }^{147}$ 


\subsection{PERMISSION TO REMAIN UNDER SECTION 49 OF THE INTERNATIONAL PROTECTION ACT 2015}

In contrast with beneficiaries of international protection and programme refugees, the rights enjoyed by persons granted permission to remain under section 49 of the 2015 Act are not provided for in legislation. Due to the highly discretionary nature of this status, there is less clarity regarding the rights and entitlements of permission to remain holders. Some persons granted permission to remain under section 49 of the 2015 Act may have less favourable conditions compared to international protection beneficiaries granted refugee status or subsidiary protection or programme refugees.

\subsubsection{Permission to remain}

Section 49(11) of the 2015 Act provides that where the Minister decides to give permission to remain under section 49 of the 2015 Act, it shall be deemed to be permission given under section 4 of the Immigration Act 2004. Conditions as to duration of stay are subject to ministerial discretion. ${ }^{148}$ Persons with permission to remain under section 49 of the 2015 Act can apply to vary or renew their permission under section 4(7) of the 2004 Act.

As is the case for beneficiaries of international protection and programme refugees, persons granted permission to remain under section 49 of the 2015 Act are issued with a Stamp 4 residence permission, which entitles the holder to seek and enter employment and access social welfare, provided that all qualifying conditions are satisfied. ${ }^{149}$ Persons granted permission to remain under section 49 of the 2015 Act can apply for naturalisation after five years' residence. ${ }^{150}$

\subsubsection{Accommodation}

Accommodation is not provided by the State for persons granted permission to remain under section 49 of the 2015 Act.

According to Housing Circular 41/2012 on access to housing supports for non-EEA nationals, a former international protection applicant granted leave to remain may be considered for assessment of social housing support on the same basis as an Irish citizen, provided they have 'a letter from the Department of Justice giving leave to remain on foot of the applicant's representations under section 3 of the Immigration Act, 1999' and a Stamp 4 permission (Department of Environment, Community and Local Government, 2012). While persons granted permission to remain under section 49 of the 2015 Act are not explicitly included in the Circular,

Immigration Act 2004, s 4(6)

Consultation with the Department of Justice and Equality, November 2019.

Irish Nationality and Citizenship Act 1956 (as amended), s 15. 
information provided by the Department of Housing, Planning and Local Government in response to queries made by Dublin City Council on the matter confirmed that such persons are treated in the same manner as persons granted leave to remain. ${ }^{151}$

Various NGOs and community organisations also offer supports to secure housing for persons granted permission to remain. For example, the Irish Refugee Council operates a housing programme, which provides direct support and accommodation donated by religious congregations, civil society and members of the public for persons moving out of Direct Provision. ${ }^{152}$ Supports for persons transitioning from Direct Provision into the local community are also provided by the Peter McVerry Trust Resettlement Service and Depaul Housing Association, among others. ${ }^{153,154}$

\subsubsection{Orientation and integration supports}

Holders of permission to remain under section 49 of the 2015 Act may access mainstream integration services, like all third-country nationals legally resident in Ireland. Unlike in the case of programme refugees, there are no targeted integration supports specifically for non-EEA nationals granted permission to remain under section 49 of the 2015 Act. Ní Raghallaigh et al. (2016) recommended provision of resettlement supports for those transitioning from Direct Provision to the community, similar to those provided for resettled refugees.

\subsubsection{Employment, education, medical care and social welfare}

Conditions as to engagement in employment, business or a profession in the State are subject to ministerial discretion. ${ }^{155}$ Access to medical care and social assistance are also matters within the discretion of the Minister. In practice, persons granted permission to remain under section 49 of the 2015 Act are issued with a Stamp 4 permission, which entitles the holder to seek and enter employment and access social welfare, provided that all qualifying conditions are satisfied. ${ }^{156}$ Circular 41/2012 in order to extend its provisions regarding international protection applicants granted leave to remain to persons granted permission to remain under s 49 of the 2015 Act, and to request the Minister for Housing, Planning and Local Government to issue an updated Circular to reflect the commencement of the 2015 Act. Source: Dublin City Council, 'Monthly City Council meeting, Monday 3 December 2018', available at https://councilmeetings.dublincity.ie/ieListDocuments.aspx?Cld=142\&Meetingld=3674. . Irish Refugee Council, 'A place to call home - IRC housing programme', https://www.irishrefugeecouncil.ie/integration-work-programmes/irc-housing-project. Peter McVerry Trust, 'Direct Provision Resettlement Programme', https://pmvtrust.ie/housing/direct-provisionresettlement-programme/.

154 Deaul, 'Depaul Housing Association', https://ie.depaulcharity.org/depaul-housing-association.

155 Immigration Act 2004, s 4(6).

156 Consultation with the Department of Justice and Equality, November 2019. 
While not set out in legislation, persons granted permission to remain under section 49 of the 2015 Act are entitled to access primary and secondary education, on the same basis as all children in the State. ${ }^{157}$ Unlike beneficiaries of international protection granted refugee status or subsidiary protection and persons granted leave to remain following a decision not to make a deportation order under section 3 of the 1999 Act, persons granted permission to remain under section 49 of the 2015 Act are not eligible for State funding for third-level education. Eligibility for the Free Fees Initiative and for a Student Universal Support Ireland (SUSI) grant is currently limited to non-EU nationals granted refugee status, subsidiary protection status, humanitarian leave to remain in the State prior to the coming into operation of the 1999 Act or those in respect of whom the Minister for Justice and Equality (the Minister) has granted permission to remain following a determination not to make a deportation order under section 3 of the 1999 Act. ${ }^{158}$ The Department of Education and Skills has confirmed that persons granted permission to remain pursuant to section 49 of the 2015 Act are not eligible for free fees (O’Kelly, 2019).

Prior to the 2015 Act, unsuccessful international protection applicants could obtain leave to remain in lieu of deportation after the Minister, having proposed to make a deportation under section 3 of the 1999 Act, decides against the making of a deportation order (see Section 2.4 of this report). From 31 December 2016, persons who do not qualify for international protection are no longer subject to the deportation process under section 3 of the 1999 Act and may instead be granted permission to remain under section 49 of the 2015 Act. This means international protection applicants under the 2015 Act who receive a negative decision on refugee status and subsidiary protection but are nevertheless granted permission to remain in the State are no longer included in the list of persons eligible for third-level grants. ${ }^{159}$ The Irish Refugee Council have criticised the restrictions, which they state deny access to education for persons granted permission to remain under the 2015 Act (O'Kelly, 2019).

\subsubsection{Family reunification}

Persons granted permission to remain under section 49 of the 2015 Act have no statutory entitlement to family reunification.

However, they may apply to the Minister for family members to join them in Ireland under the INIS administrative scheme set out in the Policy document on non-EEA family reunification, which is subject to the discretion of the Minister

(INIS, 2016). Persons granted permission to remain under section 49 of the 2015 
Act who hold a Stamp 4 permission may apply for family reunification under the administrative scheme after 12 months residence in Ireland and are subject to income or financial requirements set out in the policy document.

\subsubsection{Travel}

A person with permission to remain under section 49 of the 2015 Act has no express right to a travel document and in general will be required to obtain their own national passport to travel. In exceptional circumstances, and at the discretion of the Minister, a temporary travel document may be issued to a person granted leave to remain who does not have a national passport. Exceptional circumstances may include travel for medical treatment, humanitarian reasons or to obtain a passport (Stanley, 2017). However, a travel document is not issued for the purpose of supplementing the passport procurement process of other countries. Applicants are required to show evidence of efforts made to obtain a national passport and that it has been formally and unreasonably refused (INIS, 2017b; Stanley, 2017).

\subsection{LEAVE TO REMAIN FOLLOWING A DECISION NOT TO MAKE A DEPORTATION ORDER UNDER SECTION 3 OF THE IMMIGRATION ACT 1999}

\subsubsection{Permission to remain}

Leave to remain following a decision not to make a deportation order under section 3 of the 1999 Act is a highly discretionary status.

There is no express provision regarding the validity of the first residence permit as this is within the Minister's discretion. It is possible for a person with leave to remain to apply to renew or extend the permission. As this is a highly discretionary status, there are no express provisions regarding the renewal/extension process which is within the Minister's discretion.

Those granted leave to remain following a decision not to make a deportation order may be issued with either a Stamp 4 residence permission allowing them to seek and enter employment, or a Stamp 3 residence permission, which does not provide for access to the labour market or social welfare (Stanley et al., 2010).

\subsubsection{Accommodation}

Accommodation is not provided by the State for persons with leave to remain following a decision not to make a deportation order under section 3 of the 1999 Act. A non-EEA national who has been granted leave to remain following a decision not to make a deportation order under section 3 of the 1999 Act is eligible to apply to local authorities for social housing. A person who has leave to remain and applies for social housing may be considered for assessment of social housing support on the same basis as an Irish citizen, provided they hold a Stamp 4 permission, regardless of the length of prior residency (Department of Environment, Community and Local Government, 2012). 


\subsubsection{Orientation and integration supports}

Holders of leave to remain under section 3 of the 1999 Act may access mainstream integration services like all third-country nationals legally resident in Ireland. There are no targeted supports specifically for holders of leave to remain under section 3 of the 1999 Act.

\subsubsection{Employment, education, medical care and social welfare}

Rights for persons granted permission to remain following a decision not to make a deportation order under section 3 of the 1999 Act are not provided for in legislation. Conditions as to engagement in employment, business or a profession in the State are subject to ministerial discretion. ${ }^{160}$ The rights granted to a person with leave to remain vary according to their personal circumstances and the prevailing circumstances in the State, including economic factors. Some applicants may get Stamp 4 permission, which entitles them to seek employment without an employment permit and to apply for social welfare benefits, provided that all qualifying conditions are satisfied. Other applicants may get a Stamp 3 permission, which precludes holders from accessing employment or receiving social welfare benefits (Stanley et al., 2010).

Persons granted leave to remain are entitled to access primary and secondary education, on the same basis as all children in the State. ${ }^{161}$ Persons granted leave to remain following a decision not to make a deportation order under section 3 of the 1999 Act are eligible for financial support for third-level education under the Free Fees Initiative, provided certain residence conditions are met. They must have resided in Ireland for three of the five years prior to commencing a third-level programme in order to be granted support. ${ }^{162}$

\subsubsection{Family reunification}

Persons granted leave to remain following a decision not to make a deportation order under section 3 of the Immigration Act 1999 have no statutory entitlement to family reunification. However, depending on the type of stamp permission held, they may apply to the Minister for family members to join them in Ireland under the INIS administrative scheme set out in the Policy document on non-EEA family reunification, which is subject to the discretion of the Minister (INIS, 2016). Only persons with a Stamp 4 permission may apply for family reunification under the administrative scheme, subject to certain conditions. 


\subsubsection{Travel}

A person with leave to remain has no express right to a travel document and in general will be required to obtain their own national passport to travel. In exceptional circumstances, and at the discretion of the Minister, a temporary travel document may be issued to a person granted leave to remain who does not have a national passport. Exceptional circumstances may include travel for medical treatment, humanitarian reasons, or to obtain a passport (Stanley, 2017). However, a travel document is not issued for the purpose of supplementing the passport procurement process of other countries. Applicants are required to show evidence of efforts made to obtain a national passport and that it has been formally and unreasonably refused (INIS, 2017b; Stanley, 2017).

\subsection{PERMISSION TO REMAIN UNDER SECTION 4 OF THE IMMIGRATION ACT 2004}

\subsubsection{Permission to remain}

Section 4 of the Immigration Act 2004 confers a discretion on the Minister, or an immigration officer on his behalf, to issue a non-national with permission to land or be in the State.

There is no express provision regarding the validity of the first residence permit as this is within the Minister's discretion. It is possible for a person with permission under section 4 of the 2004 Act to apply to vary or renew that status under section 4(7) of the 2004 Act. There are no express provisions regarding the validity of the residence permit after renewal, which is within the Minister's discretion.

Not every stamp with which a person may be granted permission to remain under section 4 of the 2004 Act is reckonable for the purposes of an application for naturalisation. Time spent in the State on a Stamp 3 or 4 is reckonable for the purposes of applying for citizenship; however, time spent on a Stamp 0 or Stamp 2 permission, for example, is not.

\subsubsection{Accommodation}

Accommodation is not provided by the State for persons with permission to remain under section 4 of the 20014 Act.

A non-EEA national who has been granted permission to remain under section 4 of the 2004 Act may be eligible to apply to local authorities for social housing. However, unlike persons granted (programme or Convention) refugee status, subsidiary protection, leave to remain under the 1999 Act or permission to remain under the 2015 Act, persons granted permission to remain on the basis of section 4 of the 2004 Act may be required to satisfy additional requirements. Housing Circular 41/2012 states that non-EEA nationals to which specific criteria do not apply are required to provide proof of five years' reckonable residence on a Stamp 
1, 3, 4 or 5 permission (Department of Environment, Community and Local Government, 2012).

Persons with permission to remain under the 2004 Act may be able to avail of supports offered by various NGOs to secure housing (see the subsection on accommodation in Section 3.3 of this report).

\subsubsection{Orientation and integration supports}

Holders of leave to remain under section 4 of the 2004 Act may access mainstream integration services, like all third-country nationals legally resident in Ireland. There are no targeted supports specifically for holders of permission to remain under section 4 of the 2004 Act.

\subsubsection{Employment, education, medical care and social welfare}

Entitlements to access employment, education, medical care and social welfare for persons granted permission to remain under section 4 of the 2004 Act are not set out in legislation and are at the discretion of the Minister.

\subsubsection{Family reunification}

Persons with permission to remain under section 4 of the 2004 Act have no statutory entitlement to family reunification. However, depending on the type of stamp permission held, they may apply to the Minister for family members to join them in Ireland under the INIS administrative scheme set out in the Policy document on non-EEA family reunification, which is subject to the discretion of the Minister (INIS, 2016). Only persons with a Stamp 4 permission may apply for family reunification under the administrative scheme, subject to certain conditions.

\subsubsection{Travel}

A person with permission to remain under section 4 of the 2004 Act has no express right to a travel document and in general will be required to obtain their own national passport to travel. In exceptional circumstances, and at the discretion of the Minister, a temporary travel document may be issued to a person granted leave to remain who does not have a national passport. Exceptional circumstances may include travel for medical treatment, humanitarian reasons, or to obtain a passport (Stanley, 2017). However, a travel document is not issued for the purpose of supplementing the passport procurement process of other countries. Applicants are required to show evidence of efforts made to obtain a national passport and that it has been formally and unreasonably refused (INIS, 2017b; Stanley, 2017). 


\subsection{SYRIAN HUMANITARIAN ADMISSION PROGRAMME (SHAP)}

As discussed in Section 2.6 of this report, under the Syrian Humanitarian Admission Programme (SHAP), which was open for applications from 14 March to 30 April 2014, a total of 119 people were granted permission to remain in Ireland between 2014 and 2015.The conditions of the SHAP residence permission and rights to which SHAP beneficiaries are entitled are more limited than those granted to international protection beneficiaries and programme refugees.

\subsubsection{Permission to remain}

SHAP beneficiaries were granted permission to remain on a temporary basis for up to two years in the form of a SHAP authorisation stamp. The time spent resident in the State on a SHAP stamp is reckonable for the purposes of applying for Irish citizenship through naturalisation (Arnold and Quinn, 2016).

There is no automatic right to renewal of a temporary permission granted under SHAP. However, in light of the ongoing conflict in Syria, SHAP permission could be renewed on an individual basis for a further two years on application to INIS (Arnold and Quinn, 2016). ${ }^{163}$

UNHCR noted that the temporary nature of the permission caused challenges for persons seeking to access employment and third-level education (Arnold and Quinn, 2016). Some beneficiaries noted that the SHAP stamp was not well known among immigration officers, employers and other service providers, which sometimes caused delays in accessing employment, schools, language courses and medical services, as well as in opening bank accounts and obtaining a PPS number (social security number) (Arnold and Quinn, 2016). UNHCR therefore recommended that if a scheme similar to SHAP were to be established in future, state officials and employers should be informed about the SHAP stamp, or that another more recognisable stamp be issued, to avoid confusion when accessing employment and services (Arnold and Quinn, 2016).

While the SHAP residence permission was granted on a temporary basis, the Department of Justice and Equality had stated that Syrian beneficiaries would not be subject to return due to the ongoing conflict in their home country (Arnold and Quinn, 2016). Nevertheless, it was noted that, due to the insecurity of the temporary residence, and the fact that international protection status provides access to more rights and entitlements, a significant number of SHAP beneficiaries subsequently applied for international protection in Ireland (Arnold and Quinn, 2016). 


\subsubsection{Accommodation}

Sponsors were required to support and maintain beneficiaries admitted under SHAP, including being able to house beneficiaries (Arnold and Quinn, 2016).

\subsubsection{Orientation and integration supports}

Holders of permission to remain under SHAP may access mainstream integration services; however, access is limited to those services not linked to social protection (Arnold and Quinn, 2016). There are no targeted orientation or integration supports specifically for holders of permission to remain under SHAP.

\subsubsection{Employment, education, medical care and social welfare}

Persons admitted through SHAP are entitled to work, establish a business, or invest in the State and also to access early childhood, primary and secondary education for persons under the age of 18 years.

A key condition of SHAP was that the beneficiary should 'not become a burden on the State'. ${ }^{164}$ Persons admitted under SHAP are not entitled to apply for or receive non-insurance based social welfare payments or housing services by a housing authority. Sponsors are required to take full responsibility for supporting and maintaining the beneficiary for the duration of their residence in Ireland. Persons admitted to Ireland through SHAP only have access to essential medical treatment where the person or their sponsor does not have sufficient resources to cover the costs (Arnold and Quinn, 2016).

UNHCR recommended that the period of time the sponsor must materially provide for the beneficiary should be limited, in order to allow the beneficiary to transition to public services where necessary and to stop being dependant on their sponsor. UNHCR suggested that rent allowance, medical cards, reduced transportation costs for seniors and other financial assistance be considered to support beneficiaries and sponsors (Arnold and Quinn, 2016).

\subsubsection{Family reunification}

Persons granted permission to remain under SHAP do not have a statutory entitlement to family reunification. Neither are they eligible to apply for family reunification through the INIS administrative scheme (INIS, 2016).

\subsubsection{Travel}

In order to be admitted to Ireland under SHAP, beneficiaries were required to be in possession of a valid passport, or travel document, and entry visa prior to travelling to the State. 


\section{CHAPTER 4}

\section{Conclusions}

There are a number of national statuses in place in Ireland that may be granted to persons with a protection need. Not all forms of status in Ireland identified in this report were designed with the purpose of addressing protection-related issues. The study shows that national statuses discussed are diverse in terms of their policy objectives, legal basis, procedure and content. Notwithstanding this, it seeks to set out the law and policy with respect to all potential means of regularising status for those with protection needs.

Programme refugee status is provided for in section 59 of the International Protection Act 2015 (the 2015 Act), which provides that the Government or the Minister for Justice and Equality (the Minister) may grant a person permission to enter and remain in the State for resettlement or for temporary protection. Persons granted programme refugee status, the majority of whom are resettled to Ireland, have rights set out in legislation that are equivalent to Convention refugees and subsidiary protection beneficiaries in relation to education, travel, employment and access to social services, with the exception that programme refugees may be granted permission to remain in Ireland for a period of less than three years. However, in contrast to Convention refugees and other national status holders who arrived spontaneously or through relocation to Ireland, programme refugees that are resettled to Ireland under the government-led resettlement programme and the Community Sponsorship Ireland (CSI) initiative are the only group to be provided with targeted integration and orientation supports.

In addition to international protection and programme refugee status, other means of granting a status to persons for protection-related reasons are available in Irish international protection and immigration legislation. Under section 49 of the International Protection Act 2015 (the 2015 Act), where a person has applied for international protection and has been refused at first instance, the Minister shall then consider whether to grant the person concerned permission to remain in the State. The Minister also has a broad discretion to grant leave to remain to a person following a decision not to make a deportation order under section 3 of the Immigration Act 1999 (the 1999 Act), which may be granted to persons with a protection need. Section 4 of the Immigration Act 2004 (the 2004 Act) also provides a mechanism for the Minister to grant permission to be or to remain in the State.

Permission to remain under the 2015 Act, leave to remain under the 1999 Act and permission to remain under the 2004 Act are highly discretionary forms of status, and available statistics do not distinguish between grants of permission or leave to remain on a protection or non-protection basis. Due to the highly discretionary nature of permission to remain under the 2015 Act, leave to remain under the 1999 Act and permission to be, or to remain in, the State under the 2004 Act, there is 
less clarity regarding the rights and entitlements of status holders. Some persons granted statuses by way of these statutory mechanisms may have less favourable conditions compared to Convention refugee status or subsidiary protection holders, such as for example no statutory right to family reunification, differences in length of time for which permission is granted, access to a travel document in lieu of a passport and the number of years' residency required to apply for citizenship through naturalisation.

The Minister has used his discretion to establish ad hoc programmes to provide for the humanitarian admission of persons in need of protection to Ireland. Persons admitted through such schemes have been granted a variety of national statuses, the most prominent being programme refugee status. Since 2014, a number of administrative schemes established by the Government have provided for the granting of national statuses, which set out their own requirements and conditions for access. Ireland established a once-off private sponsorship scheme in 2014 in response to the Syrian conflict - the Syrian Humanitarian Admission Programme (SHAP), which resulted in 119 persons being granted permission to enter and reside in Ireland on the basis of a SHAP stamp. While some aspects of the programme were criticised - mainly, its temporary and ad hoc nature - SHAP was used as an example by stakeholders when calling for additional humanitarian admission programmes that would apply to people fleeing conflict in other countries and which would allow for a more secure national status once in Ireland. The subsequent establishment by the Government of the Irish Refugee Protection Programme (IRPP) Humanitarian Assistance Programme (IHAP) in 2017 and CSI in 2018 (which provide for persons in need of protection to be granted programme refugee status and afforded entitlements equivalent to those enjoyed by Convention refugees and Irish citizens) demonstrates how ad hoc schemes and national statuses can be used in a way that complements Ireland's international protection system and traditional resettlement route. 


\section{REFERENCES}

Arnold, S., E. Quinn, E. Gusciute and L. Kinlen (2019). 'Cultivating problems for the future: Integration supports for resettled and spontaneous refugees in Ireland', Migration Studies.

Arnold, S., C. Ryan and E. Quinn (2018). Ireland's response to recent trends in international protection applications, European Migration Network, ESRI Research Series No. 72, Dublin: Economic and Social Research Institute, available at http://emn.ie/files/p_20180605035853RecentTrendsIPApplications_2018_online. pdf.

Arnold, S., and E. Quinn (2016). Resettlement of refugees and private sponsorship in Ireland, European Migration Network, ESRI Research Series No. 55, Dublin: The Economic and Social Research Institute, available at http://emn.ie/files/p_20161213093254EMN\%20Resettlement\%20Report\%20FIN AL_13.12.2016.pdf.

Arnold, S., and E. Quinn (2017). Family reunification of non-EU nationals in Ireland, European Migration Network, ESRI Research Series No. 62, Dublin: Economic and Social Research Institute, available at http://emn.ie/files/p_201706070500182017_FamilyReunification_online.pdf.

Beirens, H., S. Maas, S. Petronella, M. van der Velden (2016). Study on the temporary protection directive: Final report, Brussels: European Commission, available at https://ec.europa.eu/home-affairs/sites/homeaffairs/files/e-

library/documents/policies/asylum/temporary-

protection/docs/final_report_evaluation_tpd_en.pdf.

Casey, C. (2015). 'Reading between the lines: The search for the legal basis of residency permission schemes for non-Irish nationals', The Irish Jurist, Vol. 53, No. 1, pp. 162173.

Council of the European Union (1999). 'Presidency Conclusions: Tampere European Council 15 and 16 October 1999', available at

https://www.consilium.europa.eu/media/21059/tampere-european-councilpresidency-conclusions.pdf.

Council of the European Union (2005). 'The Hague Programme: Strengthening freedom, security and justice in the European Union', 2005/C 53/01, available at https://eurlex.europa.eu/LexUriServ/LexUriServ.do?uri=OJ:C:2005:053:0001:0014:EN:PDF.

Council of the European Union (2015). 'Outcome of the Council Meeting: $3405^{\text {th }}$ Council meeting Justice and Home Affairs', available at https://data.consilium.europa.eu/doc/document/ST-11097-2015-INIT/en/pdf.

Department of Environment, Community and Local Government (2012). 'Access to social housing supports for non-Irish nationals - including clarification re Stamp 4 holders', Housing Circular 41/2012, available at https://www.housing.gov.ie/sites/default/files/migratedfiles/en/Publications/DevelopmentandHousing/Housing/FileDownLoad\%2C29412 $\% 2$ Cen.pdf. 
Department of Justice and Equality (2013). Annual report 2012, available at http://www.justice.ie/en/JELR/Department\%20of\%20Justice\%20and\%20Equality \%20Annual\%20Report\%202012.pdf/Files/Department\%20of\%20Justice\%20and\% 20Equality\%20Annual\%20Report\%202012.pdf.

Department of Justice and Equality (2017). 'Second audit of progress on improvements to the protection process (February 2017)', available at http://www.justice.ie/en/JELR/WG_Report_2nd_Progress_Table_2017.pdf/Files/ WG_Report_2nd_Progress_Table_2017.pdf.

Department of Justice and Equality (2019a). Community Sponsorship Ireland: Initial policy framework, available at

http://www.integration.ie/en/ISEC/Community\%20Sponsorship\%20Policy\%20Fra mework\%20WEB.pdf/Files/Community\%20Sponsorship\%20Policy\%20Framework $\% 20 W E B$.pdf.

Department of Justice and Equality (2019b). Community Sponsorship Ireland guidance for sponsors' settlement planning, available at http://www.integration.ie/en/ISEC/CSI\%20\%20Guidance\%20for\%20Sponsors\%20Settlement\%20Planning.pdf/Files/CSI\%20\%20Guidance\%20for\%20Sponsors\%20Settlement\%20Planning.pdf.

Department of Public Expenditure and Reform (2019). Public service performance report 2018, available at https://assets.gov.ie/31683/1d03eaee61a74bc0bd9b646d6c09a70e.pdf.

European Commission (2007). Green paper on the future Common European Asylum System, $\operatorname{COM}(2007) 301$ final, Brussels: European Commission, available at https://eurlex.europa.eu/LexUriServ/LexUriServ.do?uri=COM:2007:0301:FIN:EN:PDF.

European Commission (2008a). Policy plan on asylum: An integrated approach to protection across the EU, COM(2008) 360 final, Brussels: European Commission, available at https://eurlex.europa.eu/LexUriServ/LexUriServ.do?uri=COM:2008:0360:FIN:EN:PDF.

European Commission (2008b). Policy plan on asylum: An integrated approach to protection across the EU. Impact assessment, SEC(2008) 2029/2, Brussels: European Commission, available at https://eur-lex.europa.eu/legalcontent/EN/TXT/PDF/?uri=CELEX:52008SC2029\&from=EN.

European Commission (2009). Proposal for a Directive of the European Parliament and of the Council on minimum standards for the qualification and status of third-country nationals or stateless persons as beneficiaries of international protection and the content of the protection granted, $\operatorname{COM(2009)} 551$ final, Brussels: European Commission, available at https://eur-lex.europa.eu/legalcontent/EN/TXT/PDF/?uri=CELEX:52009PC0551\&from=EN.

European Commission (2015a). A European agenda on migration, COM(2015) 240 final, Brussels: European Commission, available at https://ec.europa.eu/homeaffairs/sites/homeaffairs/files/what-we-do/policies/european-agendamigration/backgroundinformation/docs/communication_on_the_european_agenda_on_migration_en. pdf 
European Commission (2015b). ANNEX to the Commission Recommendation on a European resettlement scheme, C(2015) 3560 final, Brussels: European Commission, available at http://data.consilium.europa.eu/doc/document/ST-9376-2015-ADD1/en/pdf.

European Commission (2016). Proposal for a Regulation of the European Parliament and of the Council on standards for the qualification of third-country nationals or stateless persons as beneficiaries of international protection, for a uniform status for refugees or for persons eligible for subsidiary protection and for the content of the protection granted and amending Council Directive 2003/109/EC of 25 November 2003 concerning the status of third-country nationals who are long-term residents, $\operatorname{COM(2016)} 466$ final, Brussels: European Commission, available at https://eurlex.europa.eu/resource.html?uri=cellar:6d976705-4a95-11e6-9c64-

01aa75ed71a1.0001.02/DOC_1\&format=PDF.

European Commission (2017). Commission recommendation (EU) 2017/1803 of 3 October 2017 on enhancing legal pathways for persons in need of international protection, OJ L 259, Brussels: European Commission, available at https://eurlex.europa.eu/legal-content/EN/TXT/PDF/?uri=CELEX:32017H1803\&from=EN.

European Commission (2019). Evaluation of the application of the recast Qualification Directive (2011/95/EU): Final report, Brussels: European Commission, available at https://publications.europa.eu/en/publication-detail/-/publication/e95280061ec1-11e9-8d04-01aa75ed71a1/language-en.

European Council on Refugees and Exiles (2009). Complementary protection in Europe, Brussels: European Council on Refugees and Exiles, available at https://www.ecre.org/wp-content/uploads/2016/07/ECRE-ComplementaryProtection-in-Europe_July-2009.pdf.

European Migration Network (EMN) (2010). The different national practices concerning granting of non-EU harmonised protection statuses, Brussels: European Migration Network, available at

http://www.emn.ie/media/2011_EMN_Synthesis_Report_NonEUharmonised_co mbined1.pdf.

European Migration Network (EMN) (2018). Asylum and migration glossary 6.0, Brussels: European Migration Network, available at https://ec.europa.eu/homeaffairs/sites/homeaffairs/files/what-we-

do/networks/european_migration_network/docs/interactive_glossary_6.0_final_ version.pdf.

European Migration Network (EMN) (forthcoming). Comparative overview of national protection statuses in the EU and Norway, Brussels: European Migration Network.

Fahey, É., F. McGinnity and E. Quinn (2019). Data for monitoring integration: Gaps, challenges and opportunities, Dublin: Economic and Social Research Institute and Office for the Promotion of Migrant Integration, available at https://www.esri.ie/system/files/publications/BKMNEXT373.pdf.

France terre d'asile (2008). Asile: La protection subsidiaire en Europe: Une mosaïque de droits, Les cahiers du social no. 18, Paris: France terre d'asile, available at http://www. france-terre-

asile.org/images/stories/publications/cahiersdusocial/cahier-du-social-18-ps-

web.pdf. 
Government of Ireland (2018). UNHCR resettlement handbook. Country chapter: Ireland, available at https://www.unhcr.org/3cac29da4.html.

Groarke, S., and S. Arnold (2018). Approaches to unaccompanied minors following status determination in Ireland, European Migration Network, ESRI Research Series No. 83, Dublin: The Economic and Social Research Institute, available at http://emn.ie/cat_publication_detail.jsp?clog=1\&itemID=3175\&item_name=\&t= 6.

Gusciute, E., S. Arnold and E. Quinn (2016). Integration of beneficiaries of international protection into the labour market: Policies and practices in Ireland, European Migration Network, ESRI Research Series No. 52, Dublin: The Economic and Social Research Institute, available at

http://emn.ie/files/p_201605310232142016_IntegrationofBeneficiariesofInterna tionalProtection.pdf.

Houses of the Oireachtas (2017). Report on immigration, asylum and the refugee crisis, available https://data.oireachtas.ie/ie/oireachtas/committee/dail/32/joint_committee_on justice_and_equality/reports/2017/2017-06-29_report-on-asylum-immigrationand-the-refugee-crisis_en.pdf.

Houses of the Oireachtas (2019). Report on scrutiny of the International Protection (Family Reunification) (Amendment) Bill 2017 [PMB], available at https://data.oireachtas.ie/ie/oireachtas/committee/dail/32/joint_committee_on justice_and_equality/reports/2019/2019-07-04_report-on-scrutiny-of-theinternational-protection-family-reunification-amendment-bill-2017-pmb_en.pdf.

Immigrant Council of Ireland (2015). 'Submission by the Immigrant Council of Ireland Independent Law Centre to the Joint Oireachtas Committee on Justice, Defence and Equality on the General Scheme of the International Protection Bill 2015', available at https://www.immigrantcouncil.ie/sites/default/files/2018-

02/IMM\%202015\%20Submission\%20to\%20Joint\%20Oireachtas\%20Committee\% 20on\%20Justice\%20on\%20General\%20Scheme\%20Int|\%20Protection\%20Bill.pdf.

Irish Naturalisation and Immigration Service (INIS) (2016). Policy document on non-EEA family reunification, available at

http://www.inis.gov.ie/en/INIS/Family\%20Reunification\%20Policy\%20Document. pdf/Files/Family\%20Reunification\%20Policy\%20Document.pdf.

Irish Naturalisation and Immigration Service (INIS) (2017a). Immigration in Ireland: Annual review 2016, Dublin: Department of Justice and Equality, available at http://justice.ie/en/JELR/INIS_Immigration_in_Ireland_Annual_Review_2016.pdf /Files/INIS_Immigration_in_Ireland_Annual_Review_2016.pdf.

Irish Naturalisation and Immigration Service (INIS) (2017b). 'Travel document application form', available at http://www.inis.gov.ie/en/INIS/Travel\%20Document\%20Form\%20-

\%20January2017.pdf/Files/Travel\%20Document\%20Form\%20\%20January2017.pdf.

Irish Naturalisation and Immigration Service (INIS) (2018). Immigration in Ireland: Annual review 2017, Dublin: Department of Justice and Equality, available at http://www.justice.ie/en/JELR/Immigration_in_Ireland_Annual_Review_2017.pdf /Files/Immigration_in_Ireland_Annual_Review_2017.pdf. 
Irish Refugee Council (2011). 'Comments on the general scheme of the International Protection Bill', available at

https://www.irishrefugeecouncil.ie/wp-content/uploads/2011/08/IRCs-

Comments-on-General-Scheme-of-International-Protection-Bill.final_.pdf.

Irish Refugee Council (2015). 'Recommendations on the International Protection Bill 2015', available at

https://www.irishrefugeecouncil.ie/wp-content/uploads/2015/11/IRC-

Recommendations-on-International-Protection-Bill-2015-Final.pdf.

Irish Refugee Council (2016). 'Safe and legal pathways to protection: Opportunities for Ireland', available at

https://www.irishrefugeecouncil.ie/wp-content/uploads/2011/08/Safe-Legal-

Pathways-to-Access_2Nov16_finalfor-formatting.pdf.

Irish Refugee and Migrant Coalition (2017). 'Pathways to protection and inclusion: Ireland's role in global refugee protection and migration movements', available at http://www.irmcoalition.com/uploads/1/0/6/9/106994057/imrc_pathways_to_p rotection_and_inclusion_website.pdf.

Joyce, C., and E. Gusciute (2015). Annual policy report on migration and asylum 2013: Ireland, European Migration Network, Dublin: Economic and Social Research Institute, available at

http://emn.ie/files/p_201506240303092013Annual\%20Policy\%20ReportJune201

5.pdf.

Joyce, C., and S. Whelan (2015). Annual policy report on migration and asylum 2014: Ireland, European Migration Network, Dublin: Economic and Social Research Institute, available at

http://emn.ie/files/p_20151105045843Annual\%20Policy\%20Report\%202014\%20

FINAL\%20ONLINE\%20VERSION.pdf

Kinlen, L. (2011). 'Welcome to Ireland: Seeking protection as an asylum seeker or through resettlement - Different avenues, different reception', Refuge, Vol. 28, No. 2, pp. 31-47.

McGinnity, F., E. Quinn, G. Kingston and P. O'Connell (2013). Annual monitoring report on integration 2012, Dublin: Economic and Social Research Institute and The Integration Centre.

Murphy, C. (2005). 'Refugees: Complementary protection in Ireland', Irish Law Times, Vol. 23, No.1, pp. 183-188.

Nasc (2016). 'Submission to the Joint Committee on Justice and Equality: Safe passage: A new approach to the refugee crisis - Humanitarian admission for families fleeing conflict', available at

https://nascireland.org/sites/default/files/Safe\%20Passage\%20Submission\%20\& \%20Statement\%202016\%20FINAL.pdf.

Ní Raghallaigh, M., M. Foreman and M. Feeley (2016). Transition from Direct Provision to life in the community: The experiences of those who have been granted refugee status, subsidiary protection or leave to remain in Ireland, Dublin: Irish Research Council and Irish Refugee Council, available at https://www.irishrefugeecouncil.ie/wp-content/uploads/2016/07/Transitionfrom-Direct-Provision-to-life-in-the-community_M-NiRaghallaigh_M-Foreman-etal-2016.pdf. 
Ní Raghallaigh, M., K. Smith and J. Scholtz (2019). Safe haven: The needs of refugee children arriving in Ireland through the Irish refugee protection programme: An exploratory study, Dublin: Children's Rights Alliance, available at https://www.childrensrights.ie/sites/default/files/Safe\%20Haven\%20Main\%20Re port.pdf.

O'Kelly, E. (2019). 'Refugee Council critical of asylum seeker education restrictions', RTÉ, 14 September 2019, https://www.rte.ie/news/education/2019/0914/1075820asylum-third-level-grant/.

O'Regan, C. (1997). Report of a survey of the Vietnamese and Bosnian refugee communities in Ireland, Refugee Resettlement Research Project, available at https://www.lenus.ie/bitstream/handle/10147/46537/1634. pdf;jsessionid=6338 830107794356871123 F680F2BCD7? sequence $=1$.

Office of the Refugee Applications Commissioner (2011). Annual report - 2010, Dublin: Office of the Refuge Applications Commissioner, available at http://www.orac.ie/website/orac/oracwebsite.nsf/page/CRSE-8XZGJD13225910en/\$File/Office\%20of\%20the\%20Refugee\%20Applications\%20Commissioner\%20\%20Annual\%20Report\%20-\%202010.pdf.

Office of the Refugee Applications Commissioner (ORAC) (2012). Annual report - 2011, Dublin: Office of the Refuge Applications Commissioner, available at http://www.orac.ie/website/orac/oracwebsite.nsf/page/CRSE-8XZGK713241510en/\$File/Office\%20of\%20the\%20Refugee\%20Applications\%20Commissioner\%20\%20Annual\%20Report\%20-\%202011.pdf.

Office of the Refugee Applications Commissioner (ORAC) (2013). Annual report - 2012, Dublin: Office of the Refuge Applications Commissioner, available at http://www.orac.ie/website/orac/oracwebsite.nsf/page/AJNR-994HLR14175828en/\$File/Office\%20of\%20the\%20Refugee\%20Applications\%20Commissioner\%20\%20Annual\%20Report\%202012.pdf.

Office of the Refugee Applications Commissioner (ORAC) (2014). Annual report - 2013, Dublin: Office of the Refuge Applications Commissioner, available at http://www.orac.ie/website/orac/oracwebsite.nsf/page/AJNR-9LED5Q1029825en/\$File/Office\%20of\%20the\%20Refugee\%20Applications\%20Commissioner\%20\%20Annual\%20Report\%202013.pdf.

Office of the Refugee Applications Commissioner (ORAC) (2015). Annual report - 2014, Dublin: Office of the Refuge Applications Commissioner, available at http://www.orac.ie/website/orac/oracwebsite.nsf/page/CRSE-9XQK2A15304722en/\$File/2014\%20Annual\%20Report.pdf.

Office of the Refugee Applications Commissioner (ORAC) (2016). Annual report - 2015, Dublin: Office of the Refuge Applications Commissioner, available at http://www.orac.ie/website/orac/oracwebsite.nsf/page/AJNR-AB7FHF12301623en/\$File/Office\%20of\%20the\%20Refugee\%20Applications\%20Commissioner\%20\%202015\%20Annual\%20Report.pdf.

Office of the Refugee Applications Commissioner (ORAC) (2017). Summary report of key developments in 2016, Dublin: Office of the Refuge Applications Commissioner, available at http://www.orac.ie/website/orac/oracwebsite.nsf/page/AJNRANKJS815175322en/\$File/Summary\%20Report\%20of\%20Key\%20Developments\%20in\%202016.pd f. 
Papadopoulou, A., B. Treviranus, T. Moritz and C.M. Fandrich (2013). Comparative study on the best practices for the integration of resettled refugees in the EU Member States, Brussels: European Parliament, available at http://www.europarl.europa.eu/RegData/etudes/etudes/join/2013/474393/IPOL -LIBE_ET(2013)474393_EN.pdf.

Pestova, N. (2017). 'Differential treatment of refugees in Ireland', Forced Migration Review, No. 54, pp. 45-47.

Pollak, S. (2019). 'Ireland wins award for community sponsorship of refugees', The Irish Times, 10 October 2019, available at https://www.irishtimes.com/news/socialaffairs/ireland-wins-award-for-community-sponsorship-of-refugees-1.4046852.

Power, J. (2018). 'Sharp fall in asylum-seekers granted humanitarian reprieve', The Irish Times, 3 February 2018, available at https://www.irishtimes.com/news/socialaffairs/sharp-fall-in-asylum-seekers-granted-humanitarian-reprieve-1.3379239.

Quinn, E., E. Gusciute, A. Barrett and C. Joyce (2014). Migrant access to social security and healthcare: Policies and practice in Ireland, European Migration Network, Dublin: Economic and Social Research Institute, available at http://emn.ie/files/p_201407170618162014_Migrant\%20Access\%20to\%20Social $\% 20$ Security.pdf.

Quinn, E., and D. Moriarty (2018). Sharing responsibility, saving lives: Reframing Ireland's response to the EU refugee crisis and beyond, Dublin: Jesuit Refugee Service Ireland, available at

http://emn.ie/files/p_201807310432502018_Sharing\%20Responsibility,\%20Savin g\%20Lives_JRS.pdf.

Refugee Appeals Tribunal (2014). Annual report 2013, available at http://www. protectionappeals.ie/website/rat/ratweb.nsf/page/MAMY-

9JPEK31141371-en/\$File/Eng\%20AReport\%202013.pdf.

Sheridan, A. (2017a). Annual report on migration and asylum 2016: Ireland, European Migration Network, Dublin: Economic and Social Research Institute, available at http://emn.ie/files/p_20171121105707Annual\%20Report\%20on\%20Migration\%2 0and\%20Asylum\%202016_online.pdf.

Sheridan, A. (2017b). Returning rejected asylum seekers: Practices and challenges in Ireland, European Migration Network, ESRI Research Series No. 65, Dublin: Economic and Social Research Institute, available at http://emn.ie/files/p_201707030349252017_EMN\%20Rejectedasylumseekers_o nline.pdf.

Sheridan, A. (2019). Annual report on migration and asylum 2018: Ireland, European Migration Network, Dublin: Economic and Social Research Institute.

Sheridan, A. and S. Whelan (2016). Annual report on migration and asylum 2015: Ireland, European Migration Network, Dublin: Economic and Social Research Institute, available at http://emn.ie/files/p_20161128025647EMN\%20AnnualPolicyReport\%202015_on line.pdf.

Stanley, J. (2017). Immigration and citizenship law, Dublin: Round Hall. 
Stanley, J., C. Joyce and E. Quinn (2010). The practices in Ireland concerning the granting of non-EU harmonised protection statuses, European Migration Network, Dublin: The Economic and Social Research Institute, available at http://emn.ie/files/p_201011241212042010_Non-

EUharmonisedProtectionStatuses_Ireland.pdf.

United Nations High Commissioner for Refugees (UNHCR) (2001). Complementary forms of protection, Geneva: UNHCR, available at https://www.refworld.org/docid/3b20a7014.html.

United Nations High Commissioner for Refugees (UNHRC) (2006). UNHCR master glossary of terms, Geneva: UNHCR, available at https://www.refworld.org/docid/42ce7d444.html.

United Nations High Commissioner for Refugees (UNHCR) (2011). UNHCR resettlement handbook, Geneva: UNHCR, available at https://www.unhcr.org/46f7c0ee2.html.

United Nations High Commissioner for Refugees (UNHCR) (2013). Towards a new beginning: Refugee integration in Ireland, Dublin: UNHCR, available at https://www.unhcr.org/en-ie/58d28aa74.pdf.

Working Group to Report to Government on Improvements to the Protection Process, including Direct Provision and Supports to Asylum Seekers (2015). Final report, available at

http://www.justice.ie/en/JELR/Report\%20to\%20Government\%20on\%20Improve ments\%20to\%20the\%20Protection\%20Process,\%20including\%20Direct\%20Provis ion\%20and\%20Supports\%20to\%20Asylum\%20Seekers.pdf/Files/Report\%20to\%2 0Government\%20on\%20Improvements\%20to\%20the\%20Protection\%20Process, \%20including\%20Direct\%20Provision\%20and\%20Supports\%20to\%20Asylum\%20S eekers.pdf. 

EMN Ireland,

Economic and Social

Research Institute,

Whitaker Square,

Sir John Rogerson's Quay,

Dublin 2, Ireland

Telephone +35318632000

Email emn.ireland@esri.ie

Web www.emn.ie / www.esri.ie

Twitter @EMNIreland

ISBN: 978-0-7070-0507-2 